Memoirs of Teaching in the Sixties and Beyond:

Teaching, Writing, and Self-Reliance

\author{
Jennifer Soalt \\ Concord, MA
}

\author{
B.A., Oberlin College, 1985 \\ M.A., University of Virginia, 1989 \\ M.ED., Harvard Graduate School of Education, 2003
}

A Dissertation presented to the Graduate Faculty of the University of Virginia in Candidacy for the Degree of

Doctor of Philosophy

\title{
English Department
}

University of Virginia

May, 2010

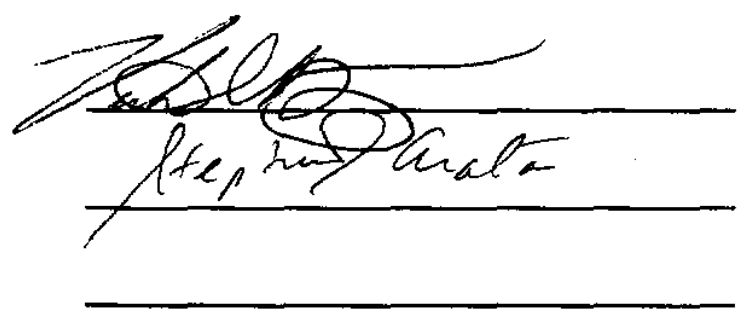




\begin{abstract}
Many memoirs of teaching were published in the sixties and early seventies. Sylvia Ashton-Warner, Jonathan Kozol, Herbert Kohl, George Dennison, Jim Haskins, James Herndon, Frank Conroy, and Philip Lopate, as well as many less well-known authors, all published memoirs of teaching between 1963 and 1975. Popular when they were first published, most of these books are still in print, or have been recently reissued, yet little has been written about them as a group or about their influence on either life writing or education.
\end{abstract}

In the memoirs of teachers from the sixties and seventies, self-reliance as personal practice becomes self-reliance as plot. Repeatedly, teacher writers build their narratives around accounts of pedagogical self-reliance, which correspond to Emerson's account of personal self-reliance. Precedents for the sixties and seventies memoirists' transformation of self-reliance from practice to plot can be found in the work of Thoreau, Dewey, and Tolstoy. The transformation of self-reliance from practice to plot, from personal philosophy to public narrative, from an individual approach to growth to an educational approach to growth, challenges us to think of self-reliance, somewhat unconventionally, as a collaborative, rather than a private, method of bringing about change and development in people and society.

Each of the four chapters of the dissertation looks at a different teaching practice or pedagogical stance intrinsic to the representation self-reliance in teachers' memoirs: the practice of challenging educational injustice; the practice of teaching writing in meaningful ways in poor communities; the practice of crossing borders between 
communities; and the practice of placing relationships at the center of teaching and learning. Each chapter begins by focusing on memoirs of teaching from the sixties and seventies, and ends by looking at how some of the issues raised in sixties and seventies memoirs have been played out in contemporary memoirs. 


\section{Contents}

Introduction: 2

Chapter 1. Memoirs of Educational Injustice 19

Chapter 2. Memoirs of Border Crossing 51

Chapter 3. Memoirs of Writing Instruction 86

Chapter 4. Memoirs of Relationship 129

Epilogue: Stories of Self-Reliance 166

Notes 169

Works Cited 169 


\section{Introduction}

"Teachers critical of Modern Schools Are Turning Into Authors," is the headline of a 1968 New York Times article (Farber 54). Much of this writing by teachers in the sixties and early seventies was autobiographical: Teacher, Death At An Early Age, 36 Children, The Lives of Children, The Diary of a Harlem School Teacher, The Way It Spozed To Be, The Water Is Wide, and Being With Children. Sylvia Ashton-Warner, Jonathan Kozol, Herbert Kohl, George Dennison, Jim Haskins, James Herndon, Pat Conroy, and Philip Lopate, as well as many less well-known writers all published memoirs of teaching in the sixties and early seventies. Many of these memoirs, popular at the time they were written, are still in print, yet little has been written about them as a group or about their influence on either life writing or education. ${ }^{1}$

Theodore Sizer in his 1973 book on school reform, Places for Learning, Places

for Joy, speaks briefly about the sixties and early seventies teacher writers as a group. He emphasizes the memoirists' interest in students as individuals: "above all, children must be respected as individuals as important and as precious as any adult of whatever renown. (62)" Sizer attributes the memoirists' insistence on respecting children as individuals to their interest in the work of Sylvia Ashton-Warner, Paul Goodman, and the English exponents of open primary schools, as well as to their reading of Froebel, Piaget, Dewey, and Bruner (64). Theodore Sizer, also points out that many of the memoirists' ideas about the value of individualism can be traced back to "a long, American philosophical tradition" (64). 
Taking as my starting point Theodore Sizer's recognition that the sixties and seventies memoirs of teaching emphasize respect for students as individuals, I argue that that the memoirs also emphasize respect for teachers as individuals, that the memoirists, in fact, see the fostering of individualism in teachers and students as entwined. Again and again, the memoirists portray themselves as teachers searching for ways to be self-reliant. The memoirists strive to be self-reliant for a wide variety of reasons: to keep their integrity in a seemingly immoral system, to challenge inadequate or damaging educational practices, to keep boredom at bay, to teach their students how to think independently, like themselves. Given the significance of the search for self-reliance in sixties and seventies memoirs of teaching, I read the "long American philosophical tradition" to which Sizer alludes as the on-going exploration of self-reliance in the work of Emerson, Thoreau, and Dewey. Martin Bickman in Minding American also reads the work of the sixties and seventies teacher writers as related to the work of Emerson, Thoreau, and Dewey, but he emphasizes their common interest in active learning, not their common interest in self-reliance.

Lawrence Buell's interpretation of Emersonian self-reliance as "a personal life practice" helps elucidate the significance of self-reliance in memoirs of teaching from the sixties and seventies. Drawing on the work of George Kateb, Lawrence Buell suggests that we should view Emersonian self-reliance as "a personal life practice" with three distinct phases: 1) a rejection of the stifling influence of others' opinions, a pursuit of what Kateb calls "negative individuality"; 2) a trusting of individual instinct that provides a means of freeing the self from the more formal, reason-bound arguments of others; 3) a 
critical examination of one's own instincts to make sure that they have a universal, rather than simply a personal foundation, an enactment of what Kateb calls "impersonal individuality" (65).

In the memoirs of teachers from the sixties and seventies, self-reliance as personal practice becomes self-reliance as plot. Repeatedly, teacher-writers build their narratives around three stages of pedagogical self-reliance, which correspond to Emerson's three stages of personal self-reliance: 1) the rejection of uninspiring conventional curriculum and teaching practices; 2) the development of one's own more inspiring curriculum and teaching practices, based on one's own and one's students' interests and life knowledge; 3) the recognition of the consequences, good and bad, of the use of one's own curriculum and teaching practices.

The transformation of self-reliance from practice to plot in the memoirs of the sixties and seventies teacher writers has a literary precedent in the life writing of Thoreau, who in Walden turned his personal pursuit of self-reliance into a compelling story. One keeps reading Walden to see if the independent-minded persona's rejection of conventions is going to be meaningful, to see if his personal experiment with different ways of conducting daily life produces new insights. Similarly, one keeps reading many sixties and seventies memoirs of teaching to see if the teacher writer's rejection of conventional teaching practices is going to be meaningful, to see if his or her personal experiment with different ways of teaching produces new insights.

The transformation of self-reliance from practice to plot in the memoirs of the sixties and seventies teacher writers has a pedagogical precedent in the work of Dewey, 
who in Democracy in Education makes the pursuit of self-reliance ---“freeing intelligence for individual effectiveness"---- one of the central narratives of education in a democracy, the story of what teachers and students should be doing in American schools (260). For Dewey, this tale of freedom depends on the teacher pursuing a form of "intellectual initiative," synonymous with the three stages of self-reliance in its scrutiny of prescribed practices and its openness to new, teacher-designed practices (265).

The transformation of self-reliance from practice to plot, from personal philosophy to public narrative, from an individual approach to growth to an educational approach to growth, challenges us to think of self-reliance, somewhat unconventionally, as a collaborative, rather than merely a private method, of bringing about change and development, in people and society. Just because self-reliance, as a mode of thought and behavior, supports the development of individual vision does not mean that it cannot have a role to play in the deeply social arena of educational reform. Philip Cafaro has pointed out that "the goal of self-reliance is not to maximize the ability to do without others, but rather to maximize self-consciousness and the ability to act, regardless of other people's beliefs" (110). Likewise, Lawrence Buell has pointed out that Emersonian self -reliance "prescribes not insular withdrawal but more robust coexistence" (78). Yet despite the assurance of some that self-reliance is not a self-centered daydream many American writers and intellectuals have questioned whether the notion of self-reliance and the notion of social reform can coexist as mutually beneficial democratic ideals. ${ }^{2}$ Memoirs of teaching, from the sixties and seventies, answer "yes," to this troubling question, 
suggesting that self-reliance need not be simply solipsistic and egotistical, and social reform need not be simply uniform, systematized, and unsympathetic to individuality This dissertation is subtitled "teaching, writing, and self-reliance" because the transformation of self-reliance from practice to plot stems from teacher writers' writing, as much as their teaching. A number of the sixties and seventies teacher writers claim that their writing is artless and spontaneous, an authentic journal or collection of notes, yet almost all the sixties and early seventies memoirs of teaching seem to have been shaped to tell a story of self-reliance. Jonathan Kozol claims that his memoir, Death At An Early Age, originated in a large collection of notes he took while teaching, but his book with its orderly progression through the three stages of pedagogical self-reliancecritique of current school practices, the development of iconoclastic practices, and the exploration of the consequences of such actions---does not read like simply a collection of notes. Rather the necessity of making his notes intelligible to readers, the shaping of life writing for an audience, seems to have resulted in the development of a plot centered around the unfolding of the protagonist's self-reliance. Self-reliance as practice may have been part and parcel of Kozol's daily work in the Boston public schools, but it needed the act of life writing to become a story of self-reliance, in which the plot hinges on the development of the author's independent initiative. It seems apt--an effective match of content and form-- that memoir, rather journalism or essays, should become teacher writers' vehicle for telling stories of self-reliance.

The story of how teachers develop self-reliance lies at the heart of both popular and literary memoirs of teaching, but in popular memoirs any challenge to established 
educational authority tends to be difficult, noble, and good, while in literary memoirs the same challenges to established educational authority are fraught with unexpected consequences and unforeseen costs, as well as gains, for teachers and students. While many teachers' memoirs, of both the popular and the literary variety, end with the teacher departing in high dudgeon-inevitably underappreciated for their self-reliant ways--popular and literary memoirs of teaching differ in how they reflect on this parting. The most complex memoirs of teaching often end with a sense of wistfulness---in which the teacher writer expresses a sense of having, at once, escaped something overwhelming and having been excluded from a charmed circle. Sylvia Ashton-Warner longingly watches the new "infant mistress" on the last pages of her memoir; James Herndon admits it is difficult to stop writing his epilogue and doubts that his message is clear enough as he thinks about how the all black school he has left is really no different from the all white school he has arrived at; Jim Haskins, in his conclusion, bluntly admits that the class "didn't learn as much as they should have" before he stops in the street to talk with one of his students; Herbert Kohl, at the end of the year and the end of the book, looks back with ambivalence, wondering whether it "is possible to function usefully within the existing school system" (192). In all these endings there is a tentativeness that does not seek closure, that refuses pat answers to the bewildering mixture of joy and daunting educational problems which is the teacher's lot.

With the exception of George Dennison, who acknowledges the influence of A.S. Neil's description of Summerhill on his own work, most of the sixties and seventies memoirists do not seem interested in teaching in ways that would make public schools 
wholly synonymous with free schools or schools where the central point is "to stand out of the way of the formative powers possessed by others" (Dennison, p4). Rather, the memoirists seem to want to infuse the conventional structure of public schools with more opportunities for self-reliance for both teachers and students, without wholly creating open classrooms with no restrictions. Envisioning self-reliance as central to the plot of their stories about school reform, the memoirists do not by and large wish, as A.S. Neill did, to advocate "noninterference" with the growth of the child (91). Instead, they want to propose a more personalized, individualized form of interference, in which the teacher's pedagogy is guided, not by mandates and guidelines, but by their own and the student's recognition of what is relevant and meaningful to the student's intellectual growth.

With narratives focused around the development of teacher and student initiative, the sixties and seventies memoirists advocate a form of pedagogy that I refer to as selfreliant teaching. I define self-reliant teaching as teaching grounded in intellectual independence and personal conviction, rather than mandates and guidelines. If selfreliance as defined by Emerson calls on individuals to live their own life and think their own thoughts, to trust their own responses and judgment, regardless of society's responses and expectations, then self-reliant-teaching, by extension, calls on teachers to "live" their own teaching and to have their own philosophy of teaching, to trust their own decisions and choices about how to foster learning.

Dewey in Democracy and Education essentially defines self-reliant teaching by describing its opposite: 
The best minds are not especially likely to be drawn where there is danger that they may have to submit to conditions which no self-respecting intelligence likes to put up with; and where there time and energy are likely to be so occupied with details of external conformity that they have no opportunity for free and full play of their own vigor. (264)

Teachers' interest in the development of "their own vigor," as opposed to preoccupation with the "details of external conformity" seems central to the definition of self-reliant teaching, as it is represented in sixties and seventies memoirs of teaching.

Self-reliant teaching unnerves us because it has the potential to be inspired and irresponsible, excellent and awful. Whether self-reliant teaching is excellent or awful depends on the caliber of the teaching force, as well as on how it is embedded in some form of collaborative accountability, such as ongoing discussion or standards. Selfreliant teaching may initially appear to be incompatible with standards-based reform, but, in fact, it could be the best means of ensuring meaningful, high-quality standards-based reform and genuine, as opposed to, superficial collaboration between teachers, who are personally invested in sharing their own individual, yet related practices.

One model of self-reliant teaching that seems to have had an influence on some of the sixties and seventies teacher writers is Tolsoty's description of his work as a teacher at Yasnaya Polyana, the school for peasant children he founded on his estate. Sylvia Ashton-Warner opens Teacher with a reference to Tolstoy's pedagogy and George Dennison closes The Lives of Children with a reference to his pedagogy (Warner 29) (Dennison 281-282). Leo Weiner's 1967 translation of Tolstoy's writing on education describes his highly individualistic form of pedagogy:

Tolstoy's teacher is not merely expected to transmit knowledge deemed traditionally worthy, nor even to convey the values of his contemporary society. He is not a mere 
filter for purifying and simplifying a dominant strain of culture. He is, rather, a remarkably independent and creative artist, who, by employing the modes of knowledge and inquiry within his subject, stimulates the student to understand those aspects of culture that he as teacher deems valuable. (XI)

In their descriptions of self-reliant teaching the sixties and seventies teacher writers, like Tolstoy, represent a form of teaching that focuses on what the teacher finds meaningful and valuable. This focus on what the teacher finds valuable, however, like Emerson's pursuit of self-reliance, is intended as a higher form of accountability, not as the mere exercising of whim. The turn towards memoir for the sixties and seventies teachers writers, and for Tolstoy, seems, in part, to be a way of pursuing the sort of inner scrutiny that Emerson suggests is necessary for distinguishing between self-reliant actions accountable to others, and mere whim.

The relationship between self-reliant teaching and accountability is complicated. The sixties and seventies teacher writers used self-reliance to make themselves more accountable to students and families, not less: i.e. with their self-reliant pedagogy they sacrificed accountability to bureaucracy to pursue accountability to individuals, communities, and ideals. Part of the reason some sixties and seventies teachers wrote memoirs may stem from their desire to defend this shift in accountability, from making themselves accountable to institutions-- a school or a district-- to making themselves accountable to people--students and parents.

This tendency towards a "higher," more Emersonian form of accountability in sixties and seventies memoirs of teaching may have some bearing on our current educational situation as we think about how to make our standards-driven, test-based 
forms of accountability more flexible and robust. In 2010, when Linda DarlingHammond calls for "professional accountability" as opposed to wholly bureaucratic accountability, it is not hard to hear distant echoes of the kind of rigorous, Emersonian accountability found in the sixties and seventies memoirs of teaching. According to Darling-Hammond, professional accountability "requires educators to make decisions on the basis of the best available professional knowledge; it also requires that they pledge their first commitment to the welfare of the client. Thus, rather than encouraging teaching that is procedure-oriented and rule-based, professional accountability seeks to create practices that are client-oriented and knowledge-based "(302). The sixties and seventies teacher writers would, of course, never have described their pedagogy as "client-oriented" and "knowledge-based," yet their self-reliant teaching practices aimed at educating their students, at all costs, rather than following specific procedures and rules, points in a similar direction to Linda Darling-Hammond. The most literary memoirs of teaching complicate the pursuit of Emersonian forms of professional accountability, showing the ways in which it is both problematic and highly valuable, while the more sentimental memoirs of teaching simply present Emersonian forms of professional accountability as inherently good.

With plots centered around the protagonists' development of self-reliance, memoirs of teaching from the sixties and seventies lend themselves to the representation of pedagogical practices that require some degree of defiance or at least personal initiative and originality. Four such iconoclastic practices occur repeatedly in sixties and seventies memoirs of teaching: the practice of challenging educational injustice; the 
practice of teaching writing in meaningful ways in poor communities; the practice of crossing borders between communities; and the practice of placing relationships at the center of teaching and learning. The fact that these four practices are now common or at least respected, rather than iconoclastic, testifies, in part, to the influence of the sixties and seventies memoirs of teaching. Each of the four chapters of the dissertation looks at the depiction of one of these four practices in memoirs of teaching from the sixties and after. The main focus of each chapter is on the memoirs of teaching from the sixties and seventies, with the memoirs of teaching from subsequent years included to demonstrate how some of the issues raised in the sixties and seventies memoirs have continued to be played out in contemporary memoirs and memoir-like works.

Many of the sixties and some of the seventies memoirs of teaching are angry books. Herbert Kohl captures the note of rage at the core of many of these books when he says that his students' "pain and my inability to tolerate it finally led me, four years later to write about our one year together" (viii). Similarly, Jim Haskins says that "after grappling with the decision to remain or get out I decided to record this diary, hoping it would help calm my frustrations" (21). Most of the sixties and many of the seventies memoirs of teaching are testimonies of sorts, stories which use private experience to question public problems. In their use of personal narrative to challenge social injustice, the teaching memoirs of the sixties and seventies are similar to many of the African American and holocaust memoirs of the sixties and seventies, such as Nigger, The Autobiography of Malcolm X, Manchild in the Promised Land, and Night. Unlike the personas of these memoirs, however, the sixties and seventies teacher writers are 
primarily witnesses of others' pain, witnesses who resemble survivors in their proximity to trauma, but differ quiet significantly from them in their ultimate disconnection from the ongoing, lived consequences of persecution.

As well as being angry, the sixties and seventies memoirs of teaching are joyful. The memoirists often seem disgusted and delighted, disgusted with the education system they find themselves working in and delighted with their own innovations and daily interactions with students. Like Leo Tolstoy in his account of the Yasana Polyana, many of the memoirists use narrative to convey the lived texture of life in schools, the ordinary yet surprising encounters that amuse, and sometimes change, teachers and students. George Dennison speaks of wishing "to convey the jumble of persons and real events which did in fact constitute our school" (5). The memoirists" pleasure in the "jumble," combined with their displeasure in the educational system, enables them to portray schools as at once wretched and remarkable, stunting and redemptive.

In their championing of individual initiative the sixties and seventies memoirists, implicitly and sometimes explicitly, challenge systematic, standards-based forms of educational reform, such as No Child Left Behind. In the narrative of school reform promoted under NCLB, the heroic teacher is the teacher who most conscientiously implements the effective teaching practices prescribed by others, who makes state sanctioned, research-based educational practices work in their classroom. In the narrative of school reform promoted by the sixties and seventies memoirists, the heroic teacher is the teacher who rejects the ineffective teaching practices prescribed by others, who replaces the authority of the educational establishment with their own authority, earned 
through a strenuous pursuit of self-reliance. As I read memoirs of teaching from the sixties and seventies in the current educational climate, where accountability and collaboration matters, I cannot help wondering if their vision of teaching is hopelessly dated or perversely relevant, if their insistence on teacher's self-reliance is outmoded and untenable or exactly what we need to help us attract and retain innovative, highly competent teachers.

Echoes of the sixties and seventies teacher writers' vision can be heard in some recent writing on educational reform. An article on teacher recruitment by Susan Engel, director of the Program in Teaching at Williams College, a recent exchange between Herbert Kohl and Arne Duncan in Rethinking Schools, and a recent book on "mindful teaching" by Elizabeth Macdonald and Dennis Shirley, a professor at the Lynch School of Education, all embody some of the interest in self-reliant teaching expressed by the sixties and seventies memoirists. In her 2009 article entitled "What It Takes To Become A Great Teacher" Susan Engel uses as her example of a great teacher a figure who sounds like he could have stepped out of a teacher's memoir from the sixties:

Two years ago I watched an excellent 4th grade teacher in Hoboken, NJ. All of his specific lessons and rules were quirky. He did not teach by the book. The children had lots of freedom to choose their own activities. He spent a good deal of his time recording what they were doing, rather than instructing them. They spent a lot of their time making things, rather than practicing skills. He held meetings of the whole group when there was conflict between children, but rarely identified rules, or handed out consequences. As part of his graduate work he had studied developmental psychology in depth. He knew how to think and read about children. His students behaved well, loved school, and learned a lot (Engel, Teachers College Record).

This could have been Sylvia Ashton-Warner or George Dennison fifty years ago. Engel's point is that this teacher's self-reliance, his “quirkiness," is precisely what we need to 
improve the quality of teaching in schools. Engel argues that such self-reliant teaching can be brought to scale by the more assertive recruitment and retention of excellent liberal arts graduates, but the feasibility of Engel's claim has been questioned by Kathleen McCartney, dean of the Harvard Graduate School of Education (McCartney, 2009).

In a May 2009 interview in NEA today, Arne Duncan talks about the influence of Herbert Kohl's 36 Children on his career in education. Speaking of 36 Children, Arne Duncan says "the book had a big impact on me" (Duncan, NEA Today). In the summer 2009 issue of Rethinking Schools, Herbert Kohl, in an open letter to Arne Duncan, acknowledges Arne Duncan's interest in 36 Children, and points out the difference between his vision of education in 36 Children and our current national vision of education. Driven by concerns with measurable outcomes and isolated skills, we have, according to Kohl, lost sight of the value of a "knowledgeable, active teacher" and the "essential motivation to learn" that such a teacher can instill through "dialogue, critical analysis, imaginative writing, and research" (Kohl, Rethinking Schools). We have, in other words, lost sight of narratives about educational reform that hinge on the development of self-reliance in teachers. Kohl is, in a sense, chiding Duncan and by extension recent government-driven reform efforts for their misreading of the plot of educational reform, as defined by the sixties and seventies teacher writers.

In The Mindful Teacher, published by Teacher's College Press in 2009, Elizabeth Macdonald and Dennis Shirley draw a contrast between "alienated teaching" and "mindful teaching," with "alienated teaching" defined as teaching in which "teachers 
neglect teaching practices that they believe are best suited for their pupils and instead comply with externally imposed mandates out of a deference for authority" and "mindful teaching," defined as teaching that embodies "seven synergies" $(15,61)$. The "seven synergies" include open-mindedness, loving and caring, stopping, professional expertise, authentic alignment, integration, and collective responsibility (61). Macdonald's and Shirley's schematic presentation of the contrast between "alienated teaching" and "mindful teaching" seems to owe a great deal to the self-reliant vision of the sixties and seventies teacher writers, who made narratives about teachers' quests to develop authentic pedagogy seem legitimate, relevant, and important.

The most vital legacy of the sixties and seventies memoirists' exploration of the role of self-reliance in teaching and learning may be the work of the Coalition of Essential Schools, as it is articulated in the work and writing of Theodore Sizer and Deborah Meier. As early as Places for Learning, Places of Joy, published in 1973, Theodore Sizer recognized the role of "affective individualism," and the pursuit of "a state of personal freedom" in the processes of teaching and learning (71). In Horace's Compromise, published in 1984, Sizer lists five imperatives for better schools, of which the first one is: "Give room to teachers and students to work and learn in their own, appropriate ways" (214). In explaining this imperative he calls on schools to emphasize the needs of particular students and resist "the blight of standardized required practice" (214). Similarly, Deborah Meier in her 1995 principal's memoir of Central Park East, The Power of Their Ideas, emphasizes the importance of teacher's working self-reliantly to develop their own passion for learning, as well as highly collaboratively and 
transparently to build a strong school culture. Both Sizer and Meier are similar in that they acknowledge the influence of the sixties and seventies memoirists on their own work, but they do not simply duplicate the insights of the memoirists. Rather they take up again the plot of self-reliance so ably spun out in sixties and seventies memoirs of teaching, and make it relevant to the more collaborative, more rigorous form of education reform pursued by teachers participating in the Coalition of Essential Schools in the eighties and nineties.

The fact that self-reliance as plot travels so well, from the work of the sixties and seventies memoirists to the work of more recent progressive reformers, suggests its durability and significance. Many of the sixties and seventies memoirs are still in print and many have recently been reissued. Why do we still care about these books? The reissues seem intended to challenge the bureaucratic view of educational reform offered by NCLB, but above and beyond this why do these books still seem to matter to people, most of whom are not teachers? One can read our need for stories about self-reliant teachers as a sentimental form of compensation for our national failure to implement worthwhile systemic school reform or one can read our need for such stories as a testimony to the ongoing pertinence of individual initiative in democratic education. But I think both of these high-minded justifications for the appeal of the sixties and seventies memoirs of teaching miss the mark. I think the reason for the appeal of teachers' memoirs from the sixties and seventies is more basic and more universal, more rooted in our lives at work. 
Most of us don't work in schools, but most of us do work in institutions of one sort or another, which at one time or another we have disagreed with or felt oppressed by. Sixties and seventies memoirs of teaching with their stories of self- reliance at work remind us that an authentic life, true to our own ideals, can, perhaps, be pursued in institutions, but it may come at a cost to ourselves and others. James Herndon recognized this when he titled his second memoir of teaching How to Survive In Your Native Land. With the memoir boom in the past twenty years has come many memoirs of different kinds of work - from surgery to sheep farming. Teachers' memoirs from the sixties and seventies were there before, offering a plot focused on self-reliance that helps us to make sense of our lives as individuals who work with and for others. 


\section{Chapter 1: Memoirs of Educational Injustice}

I have sometimes been called a romantic and don't deny that at the center of my work is faith that every student has a core of creativity and decency that can be elicited through education. In addition, I see education as part of the struggle for social justice, and this has pervaded my thinking and practice. I have never separated my commitment to justice from my classroom practice or from my work within the larger educational community.

\section{Herbert Kohl, The Herbert Kohl Reader}

Many sixties and seventies memoirs of teaching are testimonies to educational injustice, first-hand accounts of schools that fail to provide poor and working class students with compelling, or even adequate, educations. In this chapter, I trace how memoirs of teaching from the sixties to the present, represent teachers who challenge educational injustice by being self-reliant, and by attempting to instill self-reliance in their students. I say the teachers in these memoirs attempt to instill self-reliance in their students because these memoirs are as much about the hope of fostering self-reliant students as about the inevitable absurdity of teaching another person to be self-reliant. Underlying these memoirs' drive towards instilling self- reliance in students is the very Emersonian assumption that the capacity to think for oneself and critically question received opinion is a fundamental democratic right, the deprivation of which creates educational injustice in poor and working class schools, where students are often taught that academic achievement amounts to following directions, rather than finding one's own direction. 
Despite their fascination with self-reliance, the authors of teaching memoirs by and large do not appear to have libertarian leanings. They do not want to replace collective government-run or private attempts to remediate educational injustice in poor communities with wholly personal and individual initiatives, rather they seem compelled to pursue independent forms of educational reform because they cannot access or initiate viable collective forms of educational reform. In other words, for them self-reliant teaching appears to be a starting point, rather than an end point, a way of initiating better collective school reform, rather than a way of protesting or opposing collective school reform.

\section{Self Reliance and Educational Injustice in the Sixties: James Baldwin, Sylvia Ashton-Warner, and Johnthan Kozol}

The purpose of education, finally, is to create in a person the ability to look at the world for himself, to make his own decisions, to say to himself this is black or this is white, to decide for himself whether there is a God in heaven or not. To ask questions of the universe, and then learn to live with those questions, is the way he achieves his own identity. But no society is really anxious to have that kind of person around. What societies really, ideally, want is a citizenry which will simply obey the rules of society. If a society succeeds in this, that society is about to perish. The obligation of anyone who thinks of himself as responsible is to examine society and to try to change it and to fight it--at no matter what risk. This is the only hope society has. This is the only way societies change.

James Baldwin, A Talk to Teachers, 1963

In 1963 James Baldwin gave a talk to Harlem school teachers, which was

published in the Saturday Review. Baldwin's talk calls on teachers to use self- reliance to overturn educational injustice. He asks teachers to help their African American students scrutinize American culture and history. He hopes such scrutiny will produce free, 
democratic individuals, who can overcome oppression. Speaking of what he would teach an African American student, Baldwin says 'I would teach him that he doesn't have to be bound by the expediencies of any given Administration, any given policy, any given time---that he has the right and the necessity to examine everything" (686). "Examining everything" becomes, for Baldwin, the job of both the teacher and the student as they work to reform the education of African Americans, an approach to educational reform that echoes Emerson's, Thoreau's, and Tolstoy's emphasis on self-reliant teaching.

What Baldwin lays out in his talk---the hope that self reliant teaching can overcome educational inequity and other forms of social injustice - is explored in many sixties memoirs of teaching. An idea, a call to action, that in a talk seems morally clear cut-- patently right and doable--can change into something more murky and complicated, something more real in a memoir, where the reader --like the reader of Walden-hears about a necessarily incomplete, somewhat failed, but valiant attempt to fulfill an ideal. This is part of the appeal of memoir, in general, and memoirs of teaching, in particular. It comforts and inspires us with the view of someone else trying to do something significant that doesn't quite work or, at least, fails in some important way. So the ideal of using self-reliance to overcome educational inequity so eloquently articulated in Baldwin's talk becomes a more messy, more vital, more compromised ideal in sixties and seventies memoirs of teaching.

For Sylvia Ashton-Warner in Teacher (1963), one of the earliest of the sixties memoirs of teaching, self-reliance becomes a means of enabling her Maori students to build a bridge between the Maori-speaking culture of the pa, the community in which her 
students live, and the English speaking culture of the school, the classroom in which she teaches. Drawing on her own resources, discards the prescribed curriculum of Dick and Jane readers in favor of words and books that the children dictate and write themselves.

Ashton-Warner asks the smallest children what words they want to learn, what words they find personally significant. They tell her words like "mummy," "daddy," "kiss," "frightened," "ghost," "knife," "jet," "jalopy". Violent, powerful, exciting words. Ashton-Warner writes each child's words on cards for them to keep. She teaches each child to read their words. She calls this method of learning to read personally meaningful words, "the key vocabulary". When the children are slightly older they begin to use their collections of words, their "key vocabulary," to write their own memoir-like stories about their own lives. They learn to read connected sentences and pages of texts by reading their own self-authored books. Finally, after having entered into reading and writing English through the use of their own self-chosen words and their own self-written books, Ashton-Warner's students switch to reading and writing about published literature.

What is so compelling about this process of teaching English to Maori speaking children is the way it uses self-reliance as a bridge between cultures. Ashton-Warner's method assumes that educational inequity will not be eliminated by giving young English language learners more and more standardized material unconnected to their own lives, but by placing their own lives at the center of the processes of learning to read and write. Set off in italics, above three small photographic portraits of children, Ashton-Warner writes: "First words must have intense meaning. First words must be already part of the dynamic life. First, books must be made of the stuff of the child himself, whatever and 
wherever the child." "Whatever and wherever the child," suggests that Ashton-Warner sees the process of beginning reading and writing with self-reliant forms of learning-based on the child's own idiosyncratic vision,---as not only good practice for English language learners, but as good practice for all students.

In a chapter titled The Unlived Life, which echoes Emerson by way of Erich Fromm, Ashton-Warner makes her representation of the role of self-reliance in bilingual/bicultural education into a metaphor for the role of self reliance in all children's education, as they move from what they know to what others know: "We've lost the gracious movement from inside outward. We overlook the footing. I talk sometimes about a bridge from the pa to the European environment, but there is a common bridge for a child of any race and of more moment than any other: the bridge from the inner world outward" (95). Like Emerson, in Self Reliance, reminding us that to be authentically alive we need to ground ourselves in our own most significant instincts and intuitions, before we attempt to connect with others, Ashton-Warner suggests that children also need to ground themselves in their own most significant instincts and intuitions, before they attempt to learn what is meaningful to others. From this grounding in self-reliance, stems, what Ashton-Warner calls, "organic teaching," a form of teaching that honors the "creative vent," that encourages young children to make things that express their own spirit and ideas: to draw, to paint, to write, to sing, and to dance. "Organic teaching," like self-reliance, seems to be a potentially on-going form of personal liberation. I say potentially ongoing form of personal liberation because for Ashton-Warner, like Emerson, the encounter between the self and the other liberates the 
self only in so far as it takes the self as its starting point. Neither Emerson nor AshtonWarner seem to posit a self unchanged by others, yet both of them designate the self and its perspectives, rather than others' perspectives which have been imposed on the self, as the genuine foundation from which authentic encounters emanate.

Ashton-Warner and Emerson use figurative language to articulate what they mean by self-reliance, and they also use figurative language to show what is not selfreliance and what happens when self-reliance is crushed. For both of them the curtailment of self- reliance involves a kind of death. Emerson tells us the "the objection to conforming to usages that have become dead to you is, that it scatters your force. It loses your time and blurs the impression of your character" (124) and Ashton-Warner tells us that "there is no occasion whatever for the early imposition of dead reading, a dead vocabulary. I am so afraid of it. Its like a frame over a young tree making it grow in an unnatural shape" (95). Emerson is talking about the stultifying effect of social conventions that are irrelevant to individual adults and Ashton-Warner is talking about the stultifying affect of reading materials, most likely the Dick and Jane books, that are irrelevant to individual children. In moving this Emersonian critique from the general world of society to the specific world of curriculum and early reading texts, AshtonWarner implicitly claims that there is more at stake than boredom in the imposition of early reading materials that children find irrelevant, especially when one could so easily, as she has done, create autobiographical reading materials that enable children to more fully become the authors of their own lives. At a time when many public Kindergartens and first grades, particularly in poor communities with high numbers of English language 
learners, have been required to use published textbooks, Ashton-Warner's Emersonian critique of this practice reminds us of the high cost in terms of individual motivation, inspiration, and growth that we may be paying for the use of uniform, state and district prescribed reading texts with young children.

As the Unlived Life unfolds over the course of eight pages it becomes progressively more Emersonian. Reaching, again like Emerson, to describe self reliance through a kind of figurative language premised on dichotomies---inner and outer, truth and falsness, seeing and blindness, light and dark -- Ashton-Warner tells us that "the intent of the infant room is the nurturing of the organic idea, the preservation of inner resources, the exercise of the inner eye, and the protection of the true personality" (99). Emerson champions "whim" and Ashton-Warner tells us that "I like unpredictability and variation" (990).

Raising herself to higher pitch that can seem both slightly absurd and righteously lofty, Ashton-Warner moves from an Emersonian critique of education to an Emersonian critique of New Zealand society: "The noticeable thing in New Zealand society is the body of people with their inner resources atrophied. Seldom have they had to reach inward to grasp the thing they wanted" (96). Then fusing her Emersonian critique of education and her Emersonian critique of society, Ashton-Warner describes a professor, who has trouble getting his students to develop their own independent interpretations and opinions:

I said to a friend of mine, a professor, recently, "What kind of children arrive at the University to you?" He said, "They're all exactly the same." "But, "I said, "how can it be like that? The whole plan of primary education at least is for diversity." "Well," he 
answered, "they come to me like samples from a mill. Not one can think for himself. I beg them not to serve back to me exactly what I have given to them. I challenge them sometimes with wrong statements to provoke at least some disagreement but even that won't work." "But," I said, "you must confess to about three per cent originality." "One in a thousand," he replied. "One in a thousand...

In an infant room it is still possible to meet an interesting, unpaterned person. "In the infant room," I told this professor, "we still have identity. Its somewhere between my infant-room level and your university level that the story breaks. But I don't think it is the plan of education itself. (97-98)

Emerson, like Ashton-Warner, makes the youngest children the model of self-reliance when he reminds us that "infancy conforms to nobody," and like Ashton-Warner he narrates a kind of fall from self-reliance as we grow older (280). For both Emerson and Ashton-Warner self-reliance is intimately tied up with the unfolding of identity over time, as children mature into adults. The intertwining of self-reliance and identity is a kind of story, capable of being, in Ashton-Warner's words, broken. For both Emerson in the American Scholar and Ashton-Warner in the Unlived Life education is as much potentially the cause of the intertwining of self reliance and identity into a viable story, as that which "breaks" the story. For them, whether the story unfolds--whether the adult develops an authentic identity or identities--depends, in part, on how much the adult's formative education cultivated and preserved the self-reliance inherent in the young child that the adult once was.

Such an interpretation of self-reliance's role in the formation of identity places the cultivation of self-reliance squarely at the center of the educational endeavor, and implicates it in more than just the acquisition of resourcefulness and responsibility. Such an interpretation of self-reliance, in fact, claims that in fostering self-reliance in the 
classroom, teachers are fostering the unfolding of a story of the self that will, if it is not broken or diverted, eventually lead to a capacity for the "having of wonderful ideas," the educator Eleanor Duckworth's term for the desired outcome of education.

In the beginning of Teacher, Ashton-Warner explored how self-reliance could be used to remediate some of the injustices inherent in the education of English language learners, as her young Maori students moved from their Maori-speaking families and community to her English speaking classroom. In the end of Teacher, Ashton Warned expands her notion of the potential impact of self-reliance as she imagines it not only as a challenge to linguistic and racial injustice, but also, more broadly, as a possible challenge to the universal injustice inherent in growing up and being required to conform to society's dictums. From Ashton-Warner's and Emerson's point of view, this universal injustice is the very necessary price we all pay for being part of groups and organizations, larger, but not necessarily more meaningful than our singular selves.

Saidia's eloquent statement that "obedience is not truly performed by the body if the heart is dissatisfied" seems also appropriate to the Boston public schools. For the heart is dissatisfied here, and the obedience is perfunctory, and the whole concept of respect for unearned and undeserved authority is bitter and brittle and back-breaking to children, whether rich or poor, or black or white, within these kind of schools. Only the authority of visible character demands respect.

Jonathan Kozol, Death at an Early Age

Thoreau reaches for the Bhagda Vita and the Greek philosophers to help him turn his observations about Walden Pond into a more prophetic, more universal observance about human nature. Jonathan Kozol reaches for the words of Saidia, an ancient Jewish scholar, as he rails against an obedience manual he finds in his desk draw at the 
segregated Boston public school, where he teaches in Death at An Early Age. Saida 's words do not seem far from Emerson's words in Self-Reliance. Nor does Kozol's own epigrammatic statement: "Only the authority of visible character demands respect." So much is Emersonian about this statement - the epigrammatic style, the claim that authority is based not on conventions and titles but on character, the combination of acute precision and suggestive vagueness. It is not just "character," but "visible character," acts we can see and witness, that have true authority, but what exactly is an act of visible character? How would we know visible character if we saw it, and how could we be sure that visible character was good? Like Emerson, Kozol deliberately uses an aphoristic combination of precision and suggestive vagueness to goad us to inquire for ourselves into what a particular moral act would entail, to make us self-reliant in our interpretation of his words.

Jonathan Kozol hopes to earn "the authority of visible character" and AshtonWarner hopes to build "a bridge from the pa to the European environment." Both acts require self-reliant teaching, particularly the capacity to discard uninspiring curriculum and design more inspiring curriculum. Ashton-Warner throws out the Dick and Jane readers and replaces them with her students own words and stories, but not without first telling us why the Dick and Jane readers are irrelevant to her students. Kozol, in a decision that ostensibly costs him his job, teaches Dear Landlord, a Langston Hughes poem not in the official curriculum, but not without first telling us why the poems in the official curriculum are irrelevant to his students. Self-reliant teaching calls on teachers not only to develop curriculum which truly inspires and motivates their students, but also 
to be capable of questioning, criticizing, and analyzing the short comings, as well as the strengths, of prescribed curriculum, so that they can -- as Ashton-Warner and Kozol do - discard the prescribed curriculum in favor of the teacher-made curriculum if necessary. This discarding of official curriculum in Teacher and Death At An Early Age is not simply rebellious nonconformity for nonconformity's sake, or fussy personal preference pursued for no apparent reason, but, as in many teachers' memoirs, a carefully thought out moral act intended to address the injustice of inadequate and insignificant curriculum. Just as much of the first half of Teacher focuses on Ashton-Warner's self-reliant decision to teach her own "Key Vocabulary and "Organic Reading," rooted in the students' lives, rather than the Dick and Jane readers, much of the second half of Death at an Early Age focuses on Kozol's self-reliant decision to teach Langston Hughes' Ballad of the Landlord, despite the fact that it is not part of the official Boston public school curriculum. Sounding like someone who picks curriculum based on a combination of his own best judgment and on his students needs, Kozol tells us that "Of all of the poems of Langston Hughes that I read to my Fourth Graders, the one that the children liked most was a poem that has the title "Ballad of the Landlord." ... This poem may not satisfy the taste of every critic, and I am not making claims to immortality of a poem just because I happen to like it a great deal. But the reason this poem did have so much value and meaning for me and, I believe, for many students, is that it not only seems moving in an obvious and immediate human way but that it finds its emotion in something ordinary" (190). Here Kozol, much like Ashton-Warner with her "Key Vocabulary" and "Organic Reading," uses his own judgment, thinks for himself, and disregards conventional 
curriculum in favor of curriculum more connected to his students' everyday lives, not just to provide a more authentic and meaningful experience for himself, but to provide a more authentic and meaningful experience for his students. Here the "cycle" of self reliancethe critical questioning, the disregarding of convention, and the use of one's own judgment---is undertaken not to benefit the self, but to benefit others, thereby extending the Emersonian concept of self-reliance into a more obviously public context.

Kozol is careful to say that he doesn't just teach black poets to black childrenand in other forays away from the standard curriculum of the Boston public schools he teaches his students about Paris and Paul Klee. Similarly, Ashton-Warner is careful to say that after her Maori students learn to read from their own words and stories they begin reading published literature, as well. Both Ashton-Warner and Kozol use material related to their students' lives as a starting point, not as an end point. Neither of them ground their self-reliant teaching in their students' lives and communities in order to ghettoize their students, or define them entirely in terms of their immediate environment, but as a way to initiate a kind of self-reliance in their students that will enable them to do just the opposite of staying within the bounds of their own community, that will provide them with the confidence necessary to enable them to make the leap beyond their own communities if they wish. Behind both of their self-reliant decisions to ignore the official curriculum and teach their own curriculum, is the recognition that the kind of curriculum you teach can instill or destroy students' self- reliance. In other words, Ashton-Warner and Kozol decide to be self-reliant in the hope that their students will also become self- 
reliant. Self-reliance, an ostensibly personal form of reform, becomes in its mutuality, its shared passage between teacher and student, a deeply social form of reform.

It is this transformation of self-reliance from a practice one does alone-- an independent pursuit of a solitary individual — to a practice one does together-- a mutual endeavor between a teacher and their students--- that is, perhaps, the most significant legacy for education and literature of the sixties and seventies memoirs of teaching. In giving us representations of self- reliant teachers who seek to cultivate self reliant students the sixties and seventies memoirists have taken on the challenge of representing the mentor, who by definition must be an anti-mentor, at the same time that they have proposed one way of challenging the inequity inherent in the often homogenized and standardized education offered to poor and working class students. The memoirists have also shown that self-reliance need not be navel gazing, that at its most rigorous it might, paradoxically, be a form of authentic collaboration, as well as a form of individual endeavor.

I have been trying to tease out the relation between self-reliant teaching and the goal of instilling self-reliance in students in Teacher and Death at an Early Age. This transference of self- reliance seems to move both ways in Death At An Early Age---from student to teacher as well as teacher to student. When I first read Death at An Early Age, I was put off by what seemed to be Kozol's representation of African American students as victims, as Dickensian waifs caught in a broken system, but when I reread the book I realized something more was going on: Stephen, the abused child who we are introduced to in the first pages of Kozol's memoir, is, in his own quiet way, a model of self reliance, 
as independent-minded as Kozol himself. Horribly mistreated and beaten by teachers, Stephen still insists on drawing how he wants to draw in art class, on giving Kozol, when other teachers are not looking, small crumpled notes with quirky drawings and messages about himself. Explaining why he is fond of Stephen, Kozol says, "He always said just what he thought" (119). One could say the same of Kozol himself. Kozal opens his memoir with a portrait of Stephen's quiet, yet determined efforts at self- reliance, his pictures and his notes, and he closes his memoir with his own more vocal efforts at selfreliance, his teaching and writing. Crumpled notes and memoir — two different, yet similar paths to self-reliance as a method of questioning and challenging educational injustice. In framing his memoir, with the portrait of Stephen at the beginning and the portrait of himself at the end, Kozol suggests that not only can a teacher's act of selfreliance inspire a student to behave self-reliantly, but a student's act of self -reliance can inspire a teacher to behave self-reliantly, creating a ripple effect.

Hoping to over come the squalid conditions in the segregated school where he teaches, Kozol turns self-reliance from a private into a public practice in his classroom. Hoping to overcome the squalid conditions in segregated schools across the country, Kozol turns self-reliance from a private into a public practice in his writing. In this he has a model in Thoreau, who seems to have used the self-reliant voice inherent in life writing in similar ways to Kozol. Thoreau writes about his own life, his sojourn at Walden pond and his trip to the Concord jail, to change us, just as Kozol writes about his own life, his sovereign in a horribly mismanaged Boston public school, to change us. Both of them initially pretend otherwise. "I should not obtrude my affairs so much on the notice of my 
readers if very particular inquiries had not been made" Thoreau tell us at the beginning of Walden and Kozol, likewise, makes it appear as if he has not originally intended to burden us with his story: "Disheartened by conditions in my school building, and being an habitual note-taker, I soon began to amass a large number of envelopes of handwritten notes" (xv). But, in both cases, we, like the wedding guests listening to the ancient mariner, know, soon after the initial introductions have been made, that we are meant to be changed by these stories of self-reliance, and to enact change on their behalf. This is not life writing as navel gazing, as it sometimes presents itself today, but life writing as activism.

When I began reading and thinking about Teacher and Death At An Early Age, I was worried that they would be hopelessly dated, that despite their phenomenal popularity in the sixties and early seventies, they would not be relevant today. I had remembered both books as somewhat mired in white heroics, as stories that presented white teachers as heroes rescuing culturally oppressed others through their wise teaching. I was right in remembering them this way, and there is a strain of heroics, the underbelly of self-reliance, in both books, but there also turns out to be a lot more, a lot more that speaks to teaching and learning now, most importantly the question of the role of curricular independence in the overturning of educational injustice. Maybe the way out of educational inequity and injustice is not only through forms of large scale planning and the engineering of educational systems, but also, as Baldwin, Ashton-Warner, and Kozol suggest, through the cultivation of principled nonconformity in teachers. Teaching from 
this perspective would oblige teachers to challenge and rethink what does not work for their students.

\section{Curriculum Deviation Reconsidered: Self-Reliance and Educational Injustice in Contemporary Teaching Memoirs}

The reasons many current teacher-writers give for writing memoirs sound like the reasons many sixties teacher-writers gave for writing memoirs: to challenge unjust portrayals of urban students. Place a section of Herbert Kohl's 1988 forward to 36 Children, the memoir he published in 1967, next to a section of Gregory Michie's 2009 forward to Holler if You Hear Me, the memoir he published in 1999, and you can hear the echoes:

I was also driven to write by the academics and educational researchers who were publishing articles claiming that children like the ones I taught were emotionally and culturally deprived, had learning deficiencies, and might in fact be genetically inferior... There was no talk of radical changes in the economic and social order that was punishing the children and their families or in the pedagogy that was simply and unambiguously failing. So I decided to write about what happened in my class and let my students' voices, much more persuasive than mine, tell their story ... What I learned from teaching the thirty-six children was to distrust preconceptions of about what it is possible for young people to do. (Kohl, viii-x)

Through the inclusion of my students' voices and stories, I hope the book also provides a a window into the goodness and possibility that reside inside all children, and that it stands as a shout of protest against any notion that poor kids in our nation's cities are somehow deficient, less-than, or "socially handicapped." Their disadvantages, such as they are, arise not from within, but from a society that has for too long been unwilling to invest in them, their schools, and their communities. (Michie, xvii)

For both Kohl and Mitchie, memoir, as a genre, sets the record straight in city schools.

With its inclusions of real students' voices and stories, with its direct access to life as it is actually lived in urban classrooms, memoirs of teaching reveal truths that educational 
research and educational journalism cannot. Teacher-writers are not just challenging educational injustice by representing themselves as self-reliant teachers, but also by representing themselves as self- reliant writers, people who question the media's and the academy's representations of urban students and urban schools.

Kohl and Michie are similar in their claims that their writing-- their production of memoirs----is an act of meaningful protest, but they are markedly different in the extent to which they see self-reliant teaching and the curriculum deviation it often entails as a legitimate form of educational reform. Kohl assumes he has a right to engage in selfreliant teaching in his sixties memoir, that he can, if he wants, choose to dispense with the assigned curriculum and design his own more effective curriculum. In contrast, Mitchie acknowledges that he engaged in some self-reliant teaching, when he originally wrote his memoir in the late $90 \mathrm{~s}$, but wonders whether he would be able to teach in a selfreliant manner now:

It's quite a challenge, and I often wonder how I would've fared if I'd begun my teaching career in 2000, when the testing craze had hit full stride in Chicago, rather than in 1990. In my most hopeful moments, I imagine I would've still tied to carve out a space where kids' voices were heard and valued, where the curriculum honored their lives and experiences, where they could demonstrate what they'd learned with a video or a poem or a community-based project, not just a test score. In other moments, though, I'm not so sure. While teaching against the grain in public schools has never been easy, current policies and ground-level realities make it even more of an uphill climb. (xxvi)

"Teaching against the grain," self-reliant teaching, teaching in the style of Ashton-Warner and Kozol, teaching grounded in students' lives, opinions, and interests has become more difficult since the initiation of NCLB. Given this push back against self -reliant teaching, what kind of critique can memoir, a genre known for championing self- 
reliance, offer? Does contemporary memoir of teaching become a means of reenvisioning self-reliant teaching, at a time when it seems to be waning, or do they become chronicles of perfunctory teaching as teachers' capacity for innovation is curtailed? Are contemporary memoirs of teaching really memoirs of teaching as I have defined the genre if they chronicle perfunctory teaching, and ignore, avoid, or give up on the possibility of self-reliant teaching? Given the call for accountability and the success of some highly prescriptive educational programs, can self -reliant teaching, as it is represented in memoirs of teaching, still pose a viable challenge to educational injustice, in all its subtle and not so subtle guises?

In his most recent work, Letters to A Young Teacher (2007), Kozol seems to be calling on teachers, teacher-writers, and the general public to remember how life writing about teaching can become, as it had been in the past, a means of championing selfreliant teaching. In Letters to a Young Teacher, Kozol portrays Francesca, a self-reliant teacher, who seeks, like Kozol once did, to be a teacher of "visible character," a person whose independent thoughts and actions open up possibilities for her urban students.

Kozol's Letters to a Young Teacher is supposedly just that-letters between himself and a young teacher---but this is no more just a book of letters than Death at an Early Age was just a collection of notes or Walden was a bunch of journal entries. It is a very crafted, and possibly contrived correspondence, intended as protest literature. In other words, like Death at an Early Age, Letters to a Young Teacher cannily uses life writing to make a political point, while it claims to just be showing you some of the flotsam from one man's life. Between his first book Death at an Early Age and his most 
recent book Letters to a Young Teacher, Kozol wrote a lot of books on urban education that are closer to narrative journalism than life writing. Kozol's return to life writing in another form -letters rather than memoir-reminds us of the extent to which his work presents life writing as a form of protest literature, a tradition rooted in African-American narrative and Thoreau's work.

In a chapter titled, Teachers as Witnesses, in Letter to a Young Teacher, Kozol retells the self-reliant story he told in Death At An Early Age, the story of how in 1965 he was fired for reading a Langston Hughes poem, not in the official curriculum. He explains in a lengthy note titled, Reading Langston Hughes to My Fourth Graders, how his publisher forced him to fictionalize certain aspects of the original narrative in order to avoid humiliating Boston school administrators. He reminds us of how important the Langston Hughes poems were to his students, how some children voluntarily memorized the poems and brought the books home. He tells us that he was officially fired for “curriculum deviation" and that his students' parents protested his firing. He uses his selfreliant story to encourage Francesca and other young teachers to engage, when necessary, in their own forms of "curriculum deviation." (197).

Trying to strike a reasonable yet radical tone, Kozol encourages young teachers, such as Fransesca, to use self-reliance for both practical and political purposes, as a strategy for defying daily curricular restrictions and as a method of engaging in organized protest. Speaking of self-reliance as a strategy for defying daily curricular restrictions, Kozol tells Francesca, "there are usually at least some openings, as well, for deviation from that straight line of prescribed intentionality, and many teachers learn to camouflage 
their deviations with sufficient ingenuity so as to protect themselves from getting more attention than they'd like" (203-204). Speaking of self-reliance as a method of engaging in organized protest, he tells Fransesca "this is why I find myself encouraging the strongest-hearted teachers that I know to start the work of building a coherent oppositional mentality that will reinforce the willingness of other teachers to speak out not just as educators but also as public citizens" (205). In calling for a "coherent oppositional mentality" Kozol seems to be reaching after an illusive ideal embodied in memoirs of teaching as a genre: a hope that somehow self- reliance-a seemingly individualistic and personal form of reform---can in its transmission from teacher to teacher, and teacher to student become a viable form of educational reform.

In his quest to convince us of the value of self-reliant teaching, Kozol reminds us of the dangers inherent in its opposite: "neutered" teaching":

There are also teachers, fortunately a smaller number, who have attended education schools that are reminiscent, in the culture of timidity and self-concealment they unwittingly promoted, of some of the teacher-training colleges of the 1950s and preceding decades, in which future teachers are indoctrinated to behave as if they have no passionate opinions about almost anything at all that might conceivably be viewed as controversial. Some of these teachers have been victimized, as well, by being counseled to behave as if they have no vital or exciting private lives or any frolicsome and possibly subversive eccentricities. In a sense, they've neutered both their politics and personalities to a degree. Some do rebel against the antiseptic mind to which they've been conditioned. Others cannot seem to break out of the glaze by which their personalities have been surrounded. (On Being A Teacher, 2007)

Imagining teachers rebelling against the "antiseptic mind to which they have been conditioned" or failing to "break out of the glaze by which their personalities have been surrounded," are very Emersonian choices--the kind of choices between nonconformity and integrity on the one hand and conformity and ennui on the other hand that Emerson 
repeatedly calls on individuals to make in his essays and lectures. What is unique and startling then is not the notion of waking up to rebellion as a therapeutic project, but the placing of it in the context of public school teachers lives and work: the claim that the contemporary classroom is the ground where the Emersonian project can and should be carried out.

In Letters To A Young Teacher Kozol invites us to imagine the contemporary classroom as an Emersonian space, a place where an individual teacher's self-reliance matters. Current teaching memoirs really differ, though, in the extent to which they regard this independent pedagogical vision as feasible. Dan Brown's Great Expectations School, published in 2007, describes a year spent teaching fourth grade in a Bronx elementary school, in which no form of self-reliant teaching is an option. Given a prescribed literacy curriculum—Success for All—and Math Trailblazers — Brown dutifully adheres to what he is supposed to teach, even though he repeatedly loses the students' interest as a result. When students challenge him, laugh at the assignments, or in any way rebel he ascribes their behavior to his poor management skills, the schools lack of support, and sometimes the circumstances of the students' lives. He never seems to attribute what goes wrong in his class to the mismatch between the prescribed curriculum and the students in front of him or the mismatch between the prescribed curriculum and his own teaching style. This is very different than the sixties memoirists who, as we have seen, repeatedly attributed their problems teaching children in poor communities to the prescribed curriculum, which they promptly felt entitled to toss and replace with their own more meaningful and compelling curriculum. Brown's 
recollections of teaching in a highly standardized public school is a memoir in the literal sense of the word, but it is not a memoir of teaching as it had been defined by the sixties and seventies memoirists, who used the genre to chronicle their defiance of the system, rather than their defeat by the system.

In contrast to Brown's Great Expectations School, Julie Diamond's Welcome to the Aquarium, presents self-reliant teaching as a beleaguered, yet feasible ideal, worth standing up for and writing about. Published in 2008, Welcome to the Aquarium is a memoir about teaching in a New York kindergarten, written by a teacher who began teaching in the mid-sixties. In an interesting twist on teachers' memoirs as accounts of first year idealism and failure, Diamond offers us a teacher's memoir that is an account of a single year in the life of an experienced teacher, a year that distills more than thirty year spent teaching with interest and commitment.

Illustrated with black and white photographs, the layout of Welcome to the Aquarium in some ways resembles the layout of Ashton-Warner's Teacher, which is also illustrated with black and white photos. Diamond refers to Ashton-Warner's memoir and also the memoirs of Vivian Gussan Paley, a teacher-writer who wrote many carefully observed narratives of preschool children. Just as Ashton-Warner looks back to Tolstoy's accounts of teaching to give her work legitimacy, Diamond looks back to AshtonWarner's and Paley's work. Diamond's work is similar to Ashton-Warner's in its interest in early childhood literacy, the role of art in education, and the development of emergent curriculum, but it is very different in its more rational, logical, less poetic language. One feels with Ashton-Warner that she has taken all the intensity of the romantic poets and 
applied it to an account of teaching. This energy, passed down in Ashton-Warner's allusive, mystifying prose has seemingly helped inspire Diamond's commitment to selfreliant teaching, without causing her to foolishly emulate Ashton-Warner. AshtonWarner tells us how she makes up the "key vocabulary" and the "organic reading scheme" in words that make it sound as though self-reliant teaching, and the curriculum innovation it entails, is both a practical plan and a form of poetic inspiration. Diamond tells us how she decides to study squirrels with the children in words that make it sound as though self-reliant teaching, and the curriculum innovation it entails, is an essential and highly meaningful act, without which children would not have many opportunities to pursue their own ideas about the world.

Diamond points out that her opportunity to engage in curriculum planning, to study squirrels with the children, is somewhat unusual, since her school presents teachers with general learning objectives, but does not specify what curriculum and materials they must use to meet those objectives, whereas in other schools the sequence of instruction is often mandated, as well as the learning objectives. Diamond suggests that the antidote to this impasse is not simply more trust in teachers' capacities to plan curriculum, but more opportunities for teachers to discuss and explore curriculum possibilities together, in a context where inquiry, exploration, and uncertainty are valued as generative possibilities, rather than signs of incompetence. Diamond suggests that "if we want discussion of ideas to be a learning standard for children, it should also be a standard for teachers" (87).

Diamond's Welcome to the Aquarium, like the memoirs of many sixties and seventies teacher-writers, celebrates self-reliant teaching. It does not, however, like the 
memoirs of many sixties and seventies teacher-writers, focus on the ways self-reliant teaching challenges educational injustice. The connection between self-reliant teaching and the questioning of educational injustice so often explored in sixties teaching memoirs is now, perhaps, most intelligently explored not in teaching memoirs per se, but in related genres, connected to life writing about schools. I am thinking particularly of Nilaja's Sun's one-woman play No Child (2008), based on her experiences as a teaching artist in the New York public schools, Francois Begaudeau's novel and film, Enter Les Murs/The Class (2006), based on his experiences teaching in a French high school, and Ann Boden 's and Ryan Fleck's film Half-Nelson (2006). It may be that the self-reliant teacher challenging educational injustice with their independent practices has become too much of a cliché within the context of memoir to work well and can be more freshly approached in plays, novels, and movies or it may simply be that self-reliant teaching has become so unusual in schools it is difficult to have material for a "true" memoir with such a focus.

In the sixties, the memoirs of Ashton-Warner, Kozol, Kohl, Herndon, Haskins, and Dennison challenged the clichés surrounding the representations of self-reliant teachers in novels, plays, and movies such as The Blackboard Jungle, To Sir With Love, and Up the Down Staircase. Now, novels, plays, and movies, such as No Child, The Class and Half Nelson challenge the clichés surrounding the representation of self-reliant teachers in popular memoirs, such as Rafe Esquith's There Are No Shorcuts. A book blurb for a teaching memoir, published in 2001, promises that the memoir "captures the humanity of each boy, thus avoiding Blackboard Jungle clichés" (Robb, Publishers 
Weekly). In 2009, it might be more accurate to say the opposite-- that plays and movies like No Child, The Class, and Half-Nelson avoid the clichés of teaching memoir. One genre revitalizes the conventions of the other genre - as they flip-flop their orientation towards realism and sentiment. In the history of teaching narratives since the sixties, the vision and the ideal remains fairly constant---the representation of a self-reliant teacher who uses independent practices to challenge educational injustice---but the genre that best expresses this vision shifts and changes.

No Child from its title to its closing scene, examines the relation between teaching, educational injustice, and self-reliance. With a title that directly critiques No Child Left Behind, No Child encourages us to think about the extent to which our urban public schools have become prison-like institutions. In a one-woman performance, Nilaja Sun, the playwright and lone actor, plays herself, a teaching artist, as well as all the other characters in Malcom X Highschool, where she comes to help the most notorious class in the school put on a performance of Our Countries Good, a play about Australian prisoner's putting on a play. Part Welcome Back Carter, part Death at An Early Age, and part Being With Children, No Child turns the freighted dialogue between an idealistic teacher and her cynical students into comedy, serious social and political satire, and a heart-felt exploration of what it means to be a self-reliant African American teacher, who wishes to instill self-reliance, not obedience, in her largely African American students.

The play opens with Sun, as the blues singing old janitor, drawing our attention to the silence in the theater: "Hear that? Silence. Beautiful silence, pure silence. The kind of silence that only comes from spending years in the back woods. We ain't in the back 
woods (though I'm thinking bout retirin' there). It's 8:04 A.M.- five minutes before the start of the day. And, we on the second floor of Malcolm X High School in Bronx, USA" (5). Silence and noise, the woods and the city, solitude and community. It is hard not to hear a fleeting memory of Thoreau in his cabin at Walden in this opening. It seems as though we are being asked to think about how the self-reliance inherent in solitude and retreat, in our own personal Walden's, is related to the bustling world of cities, to the very real needs of others. Like Thoreau, Sun plans to show us self- reliance as a form of engagement, not a form of withdrawal. For both Thoreau and Sun, though, self-reliance, at first, requires a critique of convention and a turn inward to be effective. In Thoreau's case, the critique consists of a questioning of the conventional means of shaping a middle class self in Jacksonian America, and the turn inward consists of his retreat to Walden. In Sun's case, the critique consists of questioning the conventional means of shaping a teaching self under NCLB, and the turn inwards consists of these moments when she appears on stage as a narrator, a solitary janitor and quintessential blues man, singing, Trouble in Mind.

When she is not the old, blues-singing janitor Sun is all the other characters in No Child: the teachers, the students, the principal. Watching her on stage with no costumes and no props, using just her voice and choice of words, to become one character after another, until she is everyone in the school, but still her self, we are acutely aware of her solitude, of the way teachers are always in the midst of a crowd, yet always very alone and singular in their separation from the class as a group. Self-reliance is usually thought of as a philosophical outlook or an attitude of sorts, but here it almost seems to be a 
bodily state, embodied in Sun's acting, as she uses only her own resources, her voice and her body, to be so many other people. To be so many other people is the point of Sun's self-reliant acting and teaching, not to build up and solidify herself, but to lose herself in imagining others. This is self-reliance not as "insular withdrawal," but as "more robust coexistence" (Buell, 78). Self-reliance as "more robust coexistence" is the plot of many teaching memoirs from the sixties on, but in No Child self-reliance is also literally acted out before us, perhaps with the hope that we will emulate it, turning a singular, individual "act" into a form of social reform.

True to compelling memoirs of teaching, which hinge on failure more than heroism, Sun presents her self-reliance as inspiring and transformative, yet also flawed, limited, and inadequate. She shows herself, alone, failing to get the students to cooperate with her in the production of Our Countries Good. Disgusted with the students' lack of cooperation, she quits, and doesn't return to rehearsing the play until one of the more powerful students, a previous troublemaker, intercedes on her behalf. This is a conventional plot twist in stories about teaching, seen in numerous tv shows and films, but here it does a little more: it serves to remind us of the hubris and limitations of selfreliance, of how despite are self-generated bravado and idealism we may finally not be able to move anything forward without the help and sympathy of others, in this case a student, who we can assume has learned the value of self-reliance from his teacher, and is willing to stand up to his peers and convince them of the value of doing something as unconventional as putting on a play about freedom. 
Like No Child, Entre Les Murs complicates the connection between self-reliance and educational injustice established in the sixties memoirs of teaching. A novel by the French writer, Francois Begaudeau, a former teacher in the French public schools, Entre Les Murs was made into a movie in 2008, and translated into English in 2009, by Linda Asher. In Asher's translation, titled The Class, we find a novel shaped like a play, built almost entirely around dialogue in the classroom and dialogue in the teacher's room. The first person narrator, played by Begaudeau himself in the film, is a teacher in a French middle school, where most of the students are African, Middle Eastern, and Chinese immigrants.

At the beginning of the novel, there are pages after pages of petty squabbles between the teacher and his students about small infractions: wearing hats, speaking out of turn, getting up when you are supposed to sit down, bothering other students. Each infraction and the dialogue it elicits is conveyed in straightforward, matter of fact prose, leaving us free to determine whether it is the teacher or the students who are in the wrong in these small, but morally ambiguous skirmishes. As the novel goes on, these verbal jousts over manners and protocols, turn into something more educational, into Socratic debates of a sort, over everything from the meaning of grammatical tenses and the out come of soccer matches to noir films and Islamists.

In a twist on the conventional memoir of teaching, Begaudeau manages to make it clear that it is not necessarily the teacher's self-reliance that makes these Socratic dialogues possible, so much as the clash between the students' own self-reliance and the teacher's own self-reliance. The students question conventions and champion their own 
point of view, as much as if not more than their nonconformist teacher. This is not the nonconformist teacher as hero, so much as a sly recognition of recent immigration to France as a potentially democratic moment. At first glance, this urban school full of unruly immigrant students seems chaotic and pathetic, but looked at more closely the cause of the chaos, the students "attitude," is in fact a sign of hope, in its claim to a form of defiant self-reliance, which will not be ground down by the French educational system, and its stratified tracking system.

Like Death at An Early Age, The Class intends to use the representation of a selfreliant teacher to do more than just talk about education. In both books, the teacher's selfreliance becomes a kind of synecdoche for a radical skepticism about public policy, an individual longing for a more just country. Educational injustice becomes a way of talking about social injustice. Death at An Early Age, with its chronicle of racism in the Boston public schools, contributes to the Civil Rights movement. The "I" of the narrative is as much a teacher as an advocate of Civil Rights. The Class, with its chronicle of the challenges facing immigrant students in Parisian public schools, contributes to the increasingly heated post-911 dialogue about immigration and the role of immigrants in France. The "I" of the narrative is as much a teacher as an advocate of immigrant rights. Between the "I" of Death at an Early Age and the "I" of The Class there is, however, a crucial difference: the former speaks in a prophetic voice, close to the voice of Thoreau in some of his essays, and the latter speaks in a more uncertain, more provisional, more tentative contemporary voice. _Kozol presents an "I", like Thoreau's "I", hopeful of a meaningful link between acts of self-reliance and the defeat of social 
injustice, whereas Begaudeau presents an "I" that is perhaps more Satre-like, skeptical of a definite connection between acts of self-reliance and the pursuit of social justice, yet determined to explore the possibility that individualism and meaningful social change can coexist.

In The Class it is intentionally never clear whether the teacher is making the right decision about disciplining students. This representation of the morally challenged, yet conscientious teacher is not a departure from sixties memoirs of teaching, so much as an intensified version of the confessions of failure and uncertainty that run through the memoirs of Ashton-Warner, Kozol, Kohl, Dennison, Haskins, and Herndon. Half-Nelson takes this representation of the flawed yet devoted teacher one step further in its portrayal of a history teacher, who is both a crack addict and a political radical, determined to help one of his students, a girl of thirteen, stay out of the drug trade that claimed her brother, yet unable himself to quit his drug habit. Instead of the heroic white teacher saving the troubled yet noble black student, in Half-Nelson we get the heroic black student and the troubled yet noble white teacher trying, and perhaps failing, to save each other.

Combining conventions from addiction movies with conventions from movies, novels and memoirs about teaching, Half-Nelson has been called a "lament for the radical fires of the 1960's," and in many ways the main character resembles the teacherwriters of the sixties and early seventies (Dargis). He has a book case full of Marxist literature, teaches the students about Salvador Allende and Cesar Chavez, argues with an administrator about not using the teaching manual and the prescribed curriculum to teach about the Civil Rights Movement. He talks incessantly about "dialectics." Interspersed 
between his students' oral reports on the Civil Rights movement is grainy, black white film footage of moments from various sixties protest movements. We see Mario Savio, the leader of the Free Speech Movement, outside Sproul Hall in Berkeley, announcing that "There is a time when the operation of the machine becomes so odious, makes you so sick at heart, that you can't take part, that you've got to put your body upon the gears and upon the wheels, upon the levers, upon all the apparatus, and you've got to make it stop."

With its idealistic teacher who is also a crack addict, Half-Nelson seems to be asking whether self -reliance is still or ever was a path to fulfilling Savio's call to action. How much difference can one individual make and does it matter if we, as individuals, attempt to challenge educational and social injustice? The film does not offer easy answers to this question. It says yes and no. We see Dan Dunn, the main character, telling a group of women he is trying to pick up in a bar that he is a teacher, and he believes his work is meaningful if he can change just one person's life for the better. This could be a pickup line and a cliché, but it could also be a statement of truth. We see the brother of a former student of Dan's, at a bar, telling him that he inspired his sister to become a history major at Georgetown, but Dan is too wasted to hear him. This could be evidence that one person's inspired teaching matters, but the one person is so absorbed in his own pain that he does not notice. We see Dan, at home, telling his mother that one man cannot make a difference, that it was not Ellsberg who ended the war in Vietnam, but the student protests. This doubt about the efficacy of individuals seems to contradict what Dan initially told the woman in the bar about teachers changing lives, and reminds us that 
it is hard to judge the value of self-reliance as a path to political reform, that individual actions might count for more or less than we initially assume.

Half-Nelson is mostly a movie about a surprising friendship between a teacher and a student, yet with its idealistic protagonist, a figure who seems to have walked out of a sixties memoir, it also nudges us to think about the relation between self-reliance and social reform, an issue with which memoirs of teaching have been preoccupied since the sixties. Manohla Dargis has called Half Nelson an unusual contemporary film in its “insistence on political consciousness as moral imperative." I would add that HalfNelson, like No Child and The Class, insists on "political consciousness" as an individual "moral imperative." With their acknowledgement of failure, and the cost of nonconformity, the self-reliant, yet flawed and morally complex, teachers in these three contemporary plays, novels, and movies seem to be offshoots of the rebellious yet troubled teachers represented in sixties teaching memoirs, far more than they seem to be offshoots of the more morally straightforward teachers in plays, novels and movies, like To Sir With Love, Blackboard Jungle, and Up the Down Staircase. It is possible that there have been so many "good" teacher stories and teacher movies in the last thirty years that no intelligent author or director would imagine that a teacher protagonist who was not morally complex could be at all compelling.

With their quest to imagine self-reliance as a challenge to educational injustice and ultimately social injustice the sixties and seventies memoirists, and to a lesser extent the writers and filmmakers who follow them, change self-reliance from a private practice aimed at personal liberation to a public practice aimed at the liberation of others. In their 
use of self-reliance as a teaching practice, rather than as a personal philosophy, the memoirists make self-reliance into a strategy for challenging educational injustice. In a democracy, this seems both apt and problematic, apt in so far as it champions the capacity of individuals to overturn educational injustice and problematic in so far as it reifies the notion that it is the individual's, not the government's or the society's job, to challenge educational injustice.

\section{Chapter 2: Memoirs of Border Crossing}

I am also addicted to another more common image, that of the road or voyage. The best expression of it is in Ortega - that man has no nature excepting the road he has traveled. So that in The Way It Spozed To Be I wrote a travelogue. The people who read the book and wrote me about it seemed either to recognize that land as one in which they too traveled or lived, or as one so uncharted and astonishing they had difficulty believing in it. (17)

James Herndon, How To Survive In Your Native Land

You've got to be either brave or desperate to take this road, even though in the end it leads to wide and happy fields. And I'm not brave. But I've got to the wide and happy fields. I'm all too aware that they are noisy fields, since my teacher's mind has been set by the past into the tradition of silence. But they're the only fields that I can understand and believe in, I being so simple - and even though the price is professional isolation and ineradicable, inescapable and corrosive guilt, here we stay. (91)

Sylvia Ashton-Warner, "Life in a Maori School—from a diary," Teacher 
Many memoirs of teaching are accounts of border crossing, narratives of leaving one's community to teach in a different community. The borders crossed in these memoirs of teaching are those of race, class, language, culture, and sometimes nationality. Travelers, missionaries, anthropologists, social workers, emigrants, and refugees all come to mind when we think of border-crossers, and, at times, teacherwriters embody all and none of these roles in their work with other people's children. Seemingly motivated by the desire too help others, by what Anthony Appiah refers to as a sense of "obligation to others," teacher-writers' journeys into others' communities seem morally straightforward, but are, in fact, very complicated, fraught with issues of power, loss, and change, which the best memoirs of teaching explore (xv).

In this chapter I look at three types of memoirs about border crossing: memoirs of crossing borders of race in segregated schools, memoirs of crossing borders of class in working class communities, memoirs of crossing borders of language and nationality in teaching assignments outside the United States. At a time when we are supposedly living in a post-race America, yet economic and racial segregation in schools is growing, and nationalism is on the rise, articulate border crossers, such as the teacher-writers in these memoirs, seem needed, needed to remind us that it is possible for individuals to live meaningful lives which include others whose experiences are significantly different than their own (Harvard Civil Rights Project). 
Tolstoy, whose memoirs of teaching are mentioned by both Ashton-Warner and Dennison, crossed borders of class to establish a peasant school on his estate at Yasnaya Polyana. There is in Tolstoy's writing about the school at Yasnaya Polyana a constant struggling with the implications of his decision to educate peasant children in a progressive manner, as well as a visceral, physical awareness of the school itself as a kind of liminal space between the borders of his own life and the life of the peasants on his estate.

Like Tolstoy, Sylvia-Ashton-Warner crosses a number of borders in her work as a teacher, most notably borders of race and language in her instruction of Maori students. One of the few Maori teachers of her time who actually bothered to learn her students' language, Ashton-Warner seems endlessly fascinated by what she perceives as the differences between herself and her students. ${ }^{3}$ At times her ceaseless reification of difference, and insistence on the value of originary identities, reinforces the most sentimental forms of colonialism, and at times her restless curiosity about her students' lives enables her to engage in a form of cross-cultural communication that was truly innovative in the context of rural New Zealand in the fifties and sixties.

In the case of both Tolstoy and Ashton-Warner, it is easy to find some shockingly racist and classicist assumptions in their writing, but what seems worth remembering is that such assumptions are, perhaps, a consequence of crossing borders with the intentions of overcoming precisely just such assumptions. This irony of solidifying assumptions about race and class, just at the moment when the writer intends to dissolve such assumptions, will run throughout future teachers' memoirs about border crossing, as well. 
Teachers' memoirs of border crossing remind us that the attempt to understand difference always entails definitions of difference-- definitions which may be self-serving illusions, constructed to solidify the writer's own identity--yet without such mistaken definitions and the reflection they entail little progress would be made in the communication and encounter between others. These partial, flawed definitions of others are the cost of encounters at the border, but a cost worth incurring if we hope to have a pluralistic society.

Kwame Anthony Appiah in his exploration of cosmopolitanism reminds us that "conversations across boundaries can be fraught, all the more so as the world grows smaller and the stakes grow larger. It's therefore worth remembering that they can also be a pleasure. What academics sometimes dub 'cultural otherness' should prompt neither piety nor consternation" (xx). "Neither piety, nor consternation," in other words a willingness to neither idealize nor fear others, is essential to cosmopolitan encounters in which we speak with and about others across borders of race, nation, and class. This challenge to avoid piety and consternation, idealization and fear, runs throughout teachers memoirs of border crossing. The more sophisticated teacher-writers realize how they always fall short of meeting this challenge, and the less sophisticated teacher-writers often simply assume they have achieved a nuanced, complex understanding of others.

To avoid piety and consternation in their encounters with others, the sixties and seventies memoirists strive to be self-reliant. In other words, once they cross borders of race, language, and class, the memoirists find that prescribed curriculums and teaching strategies only block or side step any authentic encounter between themselves and the 
students they teach. Faced with this hindrance to genuinely communicating with their students, the memoirists, like Tolstoy before them, rely on their own intuition and ideas, rather than prescribed materials, to guide their instruction. Self-reliance, in the sense of independent thinking, leads teacher-writers to cross borders, and once they are across self-reliant teaching, as opposed to bureaucratic or merely perfunctory teaching, becomes a means of connecting with students. Often stuck with inappropriate and ineffective curriculum in poor communities, border-crossing teachers rely on self-reliant teaching--their own resources, ideas, and materials--to reach the children whom they teach.

\section{Crossing Borders of Race: Teaching in Segregated Schools}

A number of memoirs of teaching are accounts of teaching in segregated schools, legally segregated schools in the South and de facto segregated schools in the North and West. Many of these memoirs of teaching in segregated schools were published or set in the late sixties and early seventies, a time slightly after the heyday of the Civil Rights movement when protest to the Vietnam War was in full swing and there were a number of urban riots. Historical circumstances made the emergence of memoirs about teaching in segregated schools almost inevitable, as the events of the times created the context for both the writing and reading of such memoirs. The possibility of avoiding the draft, as well as contributing to the Civil Rights movement through teaching, no doubt led to the somewhat unusual circumstances of many well-educated young men, with literary ambitions, working in segregated schools, about which they could write memoirs. The turbulent social upheaval of the late sixties and early seventies-- urban unrest, the Civil 
Rights Movement, and the War on Poverty-- created a climate in which readers were obviously interested in learning more about segregated schools.

Two of the earliest memoirs of teaching in segregated schools, both of which end with the idealistic authors being fired, are James Herndon's The Way it Spozed to Be, an account of teaching in an Oakland Junior high, published in 1968, and Jonathan Kozol's, Death At An Early Age, an account of teaching in a Boston elementary school, which won the National Book Award in 1968. Three accounts of teaching in Harlem- Mary Frances Greene and Orlette Ryan's The Schoolchildren (1964), Herbert Kohl's 36 Children (1967), and James' Haskins Diary of a Harlem School Teacher (1969)---were published in the early and the late sixties. Sunny Decker's, An Empty Spoon (1969), an account of teaching high school in Philadelphia, also came out in the late sixties. Set in the South, rather than the North, Pat Conroy's The Water is Wide (1972), an account of teaching on Yamacraw island in South Carolina, and Daniel Fader's The Naked Children (1971), an account of teaching in a DC high school, were both published in the early seventies, and more recently Huston Diehl's Dream Not of Other Worlds, an account of teaching in Louisa County Virginia in the early seventies, was published in 2007.

Just as the tumultuous historical circumstances in the late sixties make the emergence of memoirs about teaching in segregated schools seem almost inevitable, the mingling of literary traditions from two very different sources - the legacy of African American autobiographical writing and the teaching memoirs of Tolstoy and AshtonWarner - seem to have provided a literary context for the emergence of teaching memoirs about segregated schools. There is a long tradition in African American writing of using 
autobiographical forms - from published first person slave narratives to the autobiography of Malcolm X-to protest racism and inequality. Only one of the authors I consider in this section on memoirs of segregated schools is African American, yet in their use of memoir - an autobiographical form - to protest racism and inequality these memoirs of teaching can be seen as related to this tradition in African American writing, as well as to the tradition of teaching memoir handed down in the work of Tolstoy and Ashton-Warner.

Crossing continents, from Russia and New Zealand to the United States, the reflective memoir of teaching, as written by Tolstoy and Ashton-Warner, becomes "grafted" onto African American traditions of using autobiographical writing to protest racism and emerges as a new form of protest literature - the critical memoir of teaching, which seeks to use memoir to intercede in the problem of segregated schools. Whether one sees white teachers use of autobiographical forms to protest racism as a form of cooption of African American autobiographical traditions or as a fruitful extension of African American autobiographical traditions depends on your point of view. It seems to me that at those times when memoirs about segregated schools give voice to the students and parents as well as the teachers they are fruitfully extending African American traditions of using autobiography to protest racism, but at those times when they focus primarily on the "heroic" actions of white teachers and the victimization of African American students and families, they are co-opting African American traditions of using autobiography to protest racism. 
The Supreme Court ruled on Brown v. the Board of Education in1954, yet for a myriad of political and social reasons many schools in the South and North remained essentially segregated well into the 1970s, and recent data on school demographics suggests that many of the gains that were originally made in school desegregation are gradually being reversed, as many African American and white students currently attend separate schools in separate neighborhoods. In other words, despite legislation, political action, and good intentions segregated schools still very much exist. Memoirs about working in segregated schools--with their textured, detailed depiction of the problems inherent in racist institutions-- have the capacity to intervene in this troublesome legacy of separate schools and also the capacity to create some problematic stereotypes of their own making.

At the same time that these memoirs remind us of how we have failed to become an integrated society, they also sometimes reify some of the most reductive images of African American and Latino students. This ironic problem of perpetuating the very injustices one seeks to overturn is, as I mentioned earlier in my discussion of Tolstoy and Ashton-Warner, one of the central paradoxes of teachers' memoirs. It is easy to use this irony to dismiss the significance of teachers' memoirs, but as I pointed out in my earlier discussion of Tolstoy and Ashton-Warner this would be shortsighted, since mistaking difference seems to be the inevitable price of encountering and naming difference, without which we would only interact with others who we imagine resemble ourselves.

Teacher-writers describing work in segregated schools tackle two central problems, one educational and one literary. The educational problem stems from the 
conditions in many segregated schools: how can one productively teach in an environment with inadequate resources, inadequate space, often unsuitable fellow staff, and children whose childhoods are both different from and similar to ones own childhood? The literary problem stems from trying to write narrative and polemic simultaneously: what literary structures and conventions can be used to make a compelling story out of one's teaching experience and also expose the shortcomings of these segregated schools? These two problems — one educational and one literary — may seem unrelated, but they are, in fact, intertwined because the ways in which teacherwriters solve the first problem, the educational one, invariably impacts the choices they make in tackling the second problem, the literary one. As a group, teacher-writers' solutions to these two intertwined problems are similar, yet also significantly different. James Herndon's The Way it Spozed To Be and Jonathan Kozol's Death at An Early Age, were two of the earliest memoirs of teaching in segregated schools, published in 1967 and 1968. Kozol's memoir won the National Book Award and has remained in print, and Herndon's book was widely reviewed and republished a few times, but has gone out of print. Yet Herndon's memoir is, perhaps, in the long run more indicative of the genre's strength---its capacity to convey the troubled, funny, resilient voices of teachers trying to do a decent job.

Herndon and Kozol solve the intertwined problems of how to teach in a segregated school and how to write about teaching in a segregated school in very different ways. Herndon's teaching and writing are reflective, tentative, and exploratory. He repeatedly circles back to reexamine and rethink what he has done in the classroom, 
as well as on the page. "After school I hurried out to the nearest bar to have a beer and think it over. Things weren't the same as they had been this morning, or even at noon," Herndon writes, and ends up reassessing his assumptions about his students as well as his instruction (31). Kozol's teaching and writing, in contrast, are very certain and unambivalent, as he uses his own strong convictions to challenge racist practices. Speaking of inheriting a class from an incompetent sub, Kozol focuses on his own competence and ethics: "The real reason that I was able to get on with those children in the state in which I found them is that I came into that room knowing myself to be absolutely on their side" (158). It is easy to imagine this statement recast in Herndon's voice as a description of the struggle to assert one's competence and ethics, rather than as a statement of the absolute rightness and effectiveness of one's convictions.

The differences in Herndon's approach to writing about a segregated school and Kozol's approach to writing about a segregated school is most evident in their portrayal of other people, both teachers and students. Both books use portraits of teachers and students to expose and explore the problems inherent in segregated schools. Herndon often uses a kind of dexterous ventriloquism to capture the character of students and teachers, as he allows his authorial commentary to gradually fade into the speech of those he is writing about. His compassionate mimicry suggests that the absurdities and injustices that arise in segregated schools are intolerable, but not singular in their intolerableness, just more intense than the cruelty and irony found in all schools. Like the complex slang speech of students themselves, the point of view embodied in Herndon's riffs are sometimes difficult to interpret: at times it is unclear to what extent he is 
mocking racist epithets and to what extent he is reveling in using them. Through all of Herndon's teasing, though, the students and teachers he describes always retain their humanity, their multidimensionality, which allows them to be agents in their own right, questioning and interrogating a problematic system alongside Herndon.

Kozol's portraits of teachers and students, in contrast, are tableaus of sort, excerpts from a modern day morality play or a nineteenth century novel, portraying villains and orphans. Students are repeatedly portrayed as victims and other teachers as wholly misguided racists. A heinous reading teacher stalks through Kozol's memoir spreading insidious evil, and abused children---beaten, yelled at, and degraded-- appear in almost every chapter. It is easy to dismiss these portraits as simplistic, and they are painfully one sided, but there is something more going on here. The school Kozol worked in really was appalling, and nothing short of a Dickensian style could likely express his rage at the injustice of it all. In other words, Kozol seems to choose to take memoir further in the direction of protest literature, to weigh in more on the side of polemic and less on the side of reflection precisely because he desperately wants his writing to be a goad to change.

Similarly, it is easy to critique the way that Kozol portrays himself as a white hero and essentially fails to mention much about the African American parents and community activists, who were involved in protesting the very same conditions as himself, yet the point of Kozol's memoir seems precisely to be the creation of a clichéd hero tale, which can glean a lot of attention in a country obsessed with such tales. A more subtle, more reflective, more inclusive memoir would not be either popular literature or protest 
literature, and to make his point about segregated schools heard nationally Kozol needed to write a memoir that was both popular literature and protest literature. Considering the amount of national coverage and attention Death at An Early Age has received, the strategy of turning memoir in to both popular literature and protest literature in order to make an ethical point seems successful. Yet contemporary readers still need to ask about the cost of such success--- the elision of the many African American voices that led to change in the Boston schools, and the single-minded focus on the voice and point of view of an individual white man. In many ways, Kozol's own later work, which often seeks diligently to include the voices of the communities he writes about, addresses these very questions.

Earlier I suggested that memoirs about segregated schools can be seen as a kind of new hybrid, resulting from the grafting of the reflective tradition of memoir, exemplified by Tolstoy's and Ashton-Warner's work, and the African American tradition of using autobiography to protest racism. Given this hybrid, authors have the capacity to further emphasize the genre's inward, ruminating, self-reflective tendencies or its more outward, testimonial-driven, change-oriented tendencies. After recognizing these opposite poles, one can come to a more nuanced reading of Death at an Early Age and The Way It Spozed to Be, as seminal works that lean towards distinctively different tendencies within a single genre.

Between the two poles of reflection and testimony, between the ironic, compassionate, humor of Herndon and the forceful, prophetic voice of Kozol, is the work of Kohl, who in 36 Children (1967) repeatedly examines how Harlem, as a place and a 
community, affects the lives of his students, and his own life as a teacher. Kohl largely manages to avoid ghetto clichés and stereotypes in his portrayal of Harlem by being disarmingly honest in his accounts of his own reactions to the community, and allowing his students' own writing to convey their reactions to the community.

Two other, less well known, teaching memoirs about teaching in Harlem were published before and after 36 Children: The School Children (1964), and Diary of a Harlem Schoolteacher (1969). A kind of joint journal, ostensibly recounting events in a Harlem school where the authors, Frances Greene and Orlette Ryan, worked, The School Children, one of the first of the sixties teachers' memoirs to be published in the United States, is painful to read now, as it does exactly what Kohl seems to strive to avoid: it indulges in every ghetto cliché and stereotype ever associated with Harlem, as it portrays students and parents who are simply victims of circumstances, with no positive agency of their own. Five years after Green and Ryan, Jim Haskins also uses a journal-like form to depict his year of teaching in a Harlem school, yet he produces a very different book from his predecessors. Herbert Kohl has described Diary of a Harlem School Teacher as "a very bitter book written by a very loving man," and part of the book's strength is its capacity to expose the myriad failings of Harlem schools and the problems of the community without reducing teachers, parents, and students to clichés or stereotypes (19).

Part of what enables Haskins to succeed where Greene and Ryan fail is his matter of fact objective prose, which seems to intentionally move fast, not belaboring any observation, and ascribing the same care and weight to both small and large outrages. In 
this clipped, precise prose, we hear the trustable voice of a sympathetic observer, who is willing to leave the reader to draw their own conclusions, rather than dictating or bullying them into a particular emotional reaction. A single entry of Haskins diary -- the day Martin Luther King was shot- shows how his prose uses a jotting, reporter-like style to control and make comprehensible moments of overwhelming emotion:

Friday April 5

The death of the Reverend Martin Luther King has shaken the school. Rioting in our neighborhood kept many children at home. Many white teachers were afraid to come to school today. The children and teachers who were here were heartsick. No one wanted to do any work.

There were four false fire alarms today. Most of them occur during the lunch hour, when many junior high boys come to the building either to take their sisters and brothers home for some extra lunch or just to hang around and pull the alarm to frighten half the school to death.

Kenny still has not been to school. I called his aunt, who said his mother hasn't been home to send him off to school, and besides, she said, "he has no shoes." (109)

From the death of King to false fire alarms and a boy who has no shoes this single, short entry for April 5 covers a lot of ground fast and succinctly, leaving the reader to draw the connections between the national and the local, the tragic large scale injustices of a leader's assassination and the seemingly, ordinary everyday injustices of classes interrupted by false alarms and children with no shoes. Junior high boys come into the school either to engage in pranks — setting off the fire alarm — or alternatively to help their sisters and brothers by taking them home for "some extra lunch." In other words, their behavior could be "good" or "bad" or more realistically a mixture of both. It is this even, matter-of-fact weighting of injustices large and small that gives Haskin's prose its authority and capacity to elicit our sympathy, without undue sentiment. 
Throughout Haskins writing there is a plainspoken approach to issues of race--- a willingness to discuss, with equanimity, disagreements between black and white teachers, and black parents and white teachers---which other teacher-writers seem to studiously avoid. Haskins capacity to write more comfortably than other teacher-writers about issues of race may stem, in part, from his own background as an African American, who was raised in Alabama, where he attended segregated schools. After publishing Diary of a Harlem School Teacher, Haskins went on to write a wide variety of children's books on African American history, including a number of well-received biographies.

An important, yet often overlooked memoir, Diary of a Harlem School Teacher was out of print between 1979 and 2007. In his forward to the republication of Diary of a Harlem School Teacher in 2008, Herbert Kohl says that it "is the only diary I know of written by a black teacher who was sensitive to the needs, capacities, and culture of the students and aware of the complex racial tension and bureaucratic neglect that characterize a failing school purporting to serve poor, predominantly black students" (19). Unique in both form and content, Diary of a Harlem School Teacher, adds a new form to memoirs of teaching — the daily diary — as well as a new voice and point of view - that of an African American teacher who can speak about segregated schools with an authority that eludes his white contemporaries.

Haskins grew up attending segregated schools in the rural Alabama, but like most teacher-writers he wrote about a segregated school in a Northern city. Pat Conroy's The Water is Wide and Huston Diehl's Dream Not of Other World, in contrast, are both set in segregated schools in the rural South in the late sixties and early seventies. The 
differences between Conroy's and Diehl's books epitomize many of the changes that have occurred in the genre of teachers' memoir over the last thirty years. The Water is Wide, published in 1972, is a popular book written by a popular writer. It has been turned into a movie twice. It tells the story of a young, idealistic white man teaching in an all black school on Yamacraw island in South Carolina. Dream Not of Other Worlds, published in 2007, is a university press book written by an English professor. It has been enthusiastically reviewed on NPR. It tells the story of a young, idealistic white woman teaching in an all black school in Louisa County, Virginia. Two books with a very similar topics, but pitched at different audiences. In the late sixties and early seventies young men, such as Pat Conroy, who had literary aspirations and taught to avoid the draft as well as to contribute to the Civil Rights movement, often wrote memoirs. Many of these memoirs became the author's first books, and launched their careers as writers. More recently academics, English professors such as Huston Diehl, seem to be writing memoirs about teaching. Many of these teaching memoirs are written after their authors have published a number of other books and articles. What was a genre mostly taken up by well-educated young men in the sixties and early seventies has become a genre often taken up by middle age academics of both sexes. With the shift from young to middle age writers, from "instant" memoir to distant memoir, the scope of time and the range of memory possible in teaching memoir has shifted, as writers recall classroom experiences, which occurred not last month or last year, but twenty or even thirty years ago.

Initially, The Water is Wide and Dream Not of Other Worlds appear to be very different books, but they share many attributes that are common to memoirs about 
teaching in segregated schools, in particular. The "I" of Conroy's memoir, the persona/narrator he creates, is a recent graduate of the Citadel, a Beaufort South Carolina native, who scrutinizes and questions the norms of his own community in an attempt to overcome the racism surrounding him, but who does not give up his appreciation of Southern traditions and manners. The "I" of Diehl's memoir, the persona/ narrator she creates, is, in contrast to Conroy's young Southern "I", a reflective, middle-aged Northern academic, a professor looking back at her younger, more naïve self, trying to understand her earlier perceptions of teaching, race, the South, and social justice, as well as the actual history of the community in which she taught.

Poststructuralist theory has enabled academics to decenter and undercut the determinism surrounding definitions of race, to reveal the ways in which notions of race are socially and culturally, rather than biologically, constructed. Memoirs of teaching as a genre also moves in this direction - opening up a space for authors to reflect on and deconstruct oppressive notions of race---at the same time that memoirs of teaching as a genre also inadvertently and often unintentionally moves in the opposite direction--reifying deterministic notions of race.

An idealistic, young Southern white man writing in the sixties, and a worldly white academic writing today would be expected to portray Southern African-American communities very differently, and Conroy and Diehl do just that, but they both, in different formats, deconstruct deterministic views of race. Conroy questions culturally and socially constructed views of race when he scrutinizes the way he was taught to treat African Americans in his high school years and in his early teaching. Diehl questions 
culturally and socially constructed views of race when she researches the history of Luisa county, and places her own and her students' experiences in the broader historical context of the racism that had been unfolding for years before her students were born and she became a teacher. Defiance on Conroy's part, careful archival research on Diehl's part, very different strategies, with a similar aim: the attempt to loosen fixed notions of who blacks and whites are. This is not to say that Conroy's book is free of the very racism it seeks to undermine - it isn't. Rather, like many memoirs of teaching in segregated schools, it inadvertently perpetuates the very injustices it seeks to overturn.

Some of the African American characters in The Water is Wide are stereotypes and clichés, as are some of the white characters, but the central concern of the narrator/persona, the quest at the center of his teaching and his writing, is to imagine a world without such clichés and stereotypes. Writing at a later date, with the benefit of hindsight and an awareness of the paradox at the heart of teaching memoirs about segregated schools - their tendency to perpetuate the very injustices they seek to overturn-- Diehl's work movingly and with scrupulous self-scrutiny questions her own former and current perceptions of the African American community in which she worked.

Looking at some of the very specific points at which Conroy's and Diehl's narratives overlap demonstrates how teaching memoirs about segregated schools have changed significantly and also remained the same over the past thirty years. Both Conroy and Diehl recount their struggles to work cooperatively with African American teachers, who do not share their untraditional, anti-authoritarian approaches to education. Conroy, 
much in the manner of Kozol in his portrait of the evil reading teacher, portrays Mrs. Brown, his students' former, more traditional teacher, as a villain from which he has rescued his students, until the end of the memoir where he grudgingly admits to understanding some of her motivation. Diehl, in contrast, makes use of the longer time sweep in her memoir to separate the naïve attitude of her twenty-year old self towards Mrs. Strickland, her students' former, more traditional African American teacher, and her current, more nuanced, more mature understanding of Mrs. Strickland. With the passage of time and the effort to understand the historical context of Luisa County, Diehl's initial resentment and indignation give ways to a hard earned appreciation of her colleague, which still leaves room for a critique of both traditional and progressive approaches to education, as they strive to address grave social injustice. This marks a true advance in the scope of teachers' memoirs, which have often simply portrayed battles between the "good," progressive, idealistic narrator telling the story and the "bad," traditional, often less educated staff with whom they worked. These battles between the "good" and the "bad" were good plot devices, and kept the reader engaged, but they limited the capacity of the genre to engage in meaningful analyses of schools, not to mention more just explorations of race, class and history. With the addition of time, distance, research, and reflection, Diehl frees memoirs of teaching, as a genre, from some of these limitations. As different as Diehl's memoir is from Conroy's in its more judicious and measured portrayal of community, it is also very similar in some specific ways that get at the core concerns of teaching memoir, and what makes it a coherent genre. Both authors recount watching footage of the first man walking on the moon with their classes, and 
both authors comment at length on how the children in their classes do not believe that people are actually walking on the moon. Both authors use the children's disbelief in the moon landing to highlight the children's distance from mainstream society, their lack of exposure to modern science and technology, their entrapment in a peasant-like world of visceral immediacy, which is the root of both their charm and their lack/need. Yet anyone who was a child at the time of the first moon landing can remember how hard it was to believe in, regardless of one's background. What I am suggesting is that memoirs of teaching, in general, and memoirs of segregated schools, in particular, seek out and reify difference, that their narrative structure depends largely on defining the students described in the memoir as different, and thereby of potential interest to the reader, who is assumed to come from a background similar to the author's, not the students. In this other-oriented context, where difference is the currency of the realm, any sign is capable of signifying difference, irregardless of whether it is also potentially a sign of unanimity/sameness, as in the case of the children's attitude towards the moon landing: a moment construed as a sign of difference could, in another context, just as easily be construed as a sign of universal childhood naïveté.

Given the way that writers of teachers' memoirs seek out and reify difference, moments when they turn the other way, when they seek out and reify similarity, stand out. One of the most notable examples of such a moment, is the close of Herndon's Way It Spozed to Be where he leaves his job teaching at a school with primarily poor, African American students to teach at a school with primarily working class white students, and finds that things aren't that different, that in fact he faces the same challenges and 
problems, in only slightly different form. Such recognitions seem democratic and useful, leaving one to ask if the more common reification of difference in memoirs of teaching is a productive uncovering of social injustice or an unproductive perpetuation of social injustice.

Besides sharing a tendency to reify difference--of which Conroy seems unaware and Diehl seems very much aware--both Conroy and Diehl share a capacity to critique their own idealism, a willingness to question their desire to make the world a better place for their students. It is easy to dismiss the Water is Wide as a simplistic, hero narrative if one has only seen the films made from the memoir, but the actual memoir, like all good teachers' memoirs is solidly grounded in self-scrutiny and self- doubt, skepticism about one's capacity to improve students' lives through thoughtful teaching:

When I first envisioned myself on the island, a noble creature enshrined among the illiterate masses working in the primitive conditions that would have warmed the cockle of Henry Thoreau's heart, I did not consider my compulsive need for friends and good conversation... Consciously I began to wish for a way to extricate myself from a job and a situation I felt incapable of handling... I became distracted with myself and my vainglorious attempt to act as a symbolic bridge between the children of the Yamacraw and the outside world" (86) (95).

In an even more self-critical vein, which initially appears to be a departure from Conroy and other sixties teacher-writers, but is, in fact an extension of their self scrutiny Diehl states:

Unlike many teaching memoirs written in that turbulent time, mine does not end in triumph, but in failure. For many years I was ashamed of my failure, and even sought to conceal it, but I now believe that one of the ways I can contribute to the national conversation about race, minority education, and the multicultural classroom is to acknowledge and try to understand the many ways I failed the African American children in my classroom. (xi) 
Diehl seems set on defining how her memoir differs from earlier memoirs in this passage, yet I would argue that what she points out as different about her memoir-its exploration of how she failed as a teacher---is, in fact, what makes her memoir the same as earlier memoirs of teaching, part of a tradition of self-conscious, self-critical idealism. True, many movies about teaching end in unqualified triumph by a heroic teacher, but none of the best known sixties or early seventies memoirs that I explore in this dissertation - the work of Ashton-Warner, Herndon, Kohl, Kozol, Dennison, and even Conroy—end in anything that could be called triumph, rather they tend to conclude with a recognition of some of the author's accomplishments, as well as their own and society's shortcomings. When we recall sixties and seventies memoirs of teaching we often think of them as ending in triumph because we conflate them with the film versions of the same narratives or other films and novels about plucky teachers, such as Up the Down Stair Case and To Sir With Love, which, I would argue, belong to a wholly different genre. Rather than seeing Diehl's willingness to analyze her own failure as a teacher as unique, as she suggests, I see it as an extension of what makes sixties and many later memoirs of teaching moving and important: their capacity to provide a space in which we can come to terms with our never fully realized desires to make a difference in the lives of others, a space where we can critique and also celebrate our very American longing to use our own initiatives and lives to enact democratic values.

The borders crossed in memoirs about teaching in segregated schools-- borders of race and class--make these narratives an ideal vehicle for examining issues of educational and social justice, and many contemporary narratives of educational rights violations, 
both in the form of life narratives and in the form of creative nonfiction, seem to have grown, in part, out of the sixties and early seventies memoirs of teaching in segregated schools. Donna Foote's Relentless Pursuit (2008), Susan Eaton's The Children in Room E4 (2007), and Abby Goodnough's Ms.Moffett's First Year (2004) are journalism, not memoirs, but, in their portrayal of educational and social injustices in urban schools, they seem to descend from sixties and seventies memoirs about segregated schools.

\section{Crossing Borders of Class: Teaching in Working Class Schools}

Both Mark Edmundson's Teacher (2002) and J.D. Scrimgeour's Themes For English B (2006) depict teachers who cross borders of class to pursue their calling, yet both books are first and foremost meditations on the question of what constitutes good teaching. Crossing borders of class in these memoirs is not in of itself the main point, rather it is the way that such crossings enable more provocative, more authentic teaching than could occur on home ground that is significant. Other similarities between the two books include the authors' accounts of sports - football in Edmundson's case and basketball in Scrimgeour's case. The consideration of how participation in school sports shapes and also sometimes thwarts the development of students' identities expands the thematic reach of teachers' memoirs, which previously seem to have included little mention of sport. Like Huston Diehl, both Mark Edmundson and J.D Scrimgeour are English professors whose memoirs seem to mark a sea change of sorts in the genre, a taking up of the form by somewhat older, academic writers, who were not represented among the initial practitioners of the genre in the sixties and early seventies, with the 
exception of Daniel Fader, who wrote the Naked Children, after taking a year leave from University of Michigan to teach in the Washington schools. With these new kinds of writers, these professors taking on a popular form, come new themes and methods of structuring memoirs of teaching, opportunities to breathe life into a genre that was in danger of solidifying into a sentimental cliché.

Edmundson tells the story of Frank Lears, a Harvard graduate with a Socratic teaching style who, in 1969, finds himself teaching high school in Medford MA, a working class town at once close to and miles away from Cambridge. A student in Lears' class, Edmundson learns from Lears how to think critically and question the world around him, a lesson that frees him to imagine a future as an intellectual, in a community that points youth in more practical directions. The fact that Lear is a border crosser, a fish out of water, a leftist intellectual in an all-American high school, makes him similar to the border crossers depicted in earlier memoirs of teaching in segregated schools in the sixties, but he is also very different from these earlier border crossers in that his story is being told by his student, not himself. This crucial difference between memoir as autobiography and memoir as simultaneously biography and autobiography demonstrates the extent to which Edmundson has expanded the range of experience encompassed by teaching memoir: a student's memoir becomes a teacher's memoir in a double sense, as Edmundson ties his own goals as a college teacher to his recollection of Lear's goals as a high school teacher.

When Herbert Kohl ended 36 Children with a description of what happened to the children in his class after the end of his memoir, he effectively freed future teacher- 
writers from the constraints of working within a single year or carefully bounded period of time. Edmundson's Teacher takes the opening up of time in memoirs of teaching a step further than Kohl, as he uses the remembered past-his life in Lears' class---to illuminate the present-his current life as a professor seeking to provoke and inspire his students, as he was once provoked and inspired by Lears.

J.D. Scrimgeour's memoir, while similar in subject, and to some extent theme, to Edmundson's book has a very different publishing history: Edmundson's Teacher, published by Random House, was widely reviewed and appeared on the New York Times best seller list; Scrimgeour's Themes for English B, published by the University of Georgia Press, won an award for creative nonfiction and was reviewed primarily in professional journals, such as Teachers College Record. In terms of audience and publishing history, then, Scrimgeour's memoir is closer to Diehl's Dream Not of Other Worlds than Edmundson's Teacher, and marks what seems to be the emergence of memoirs of teaching as a semi-scholarly university press genre, as well as a popular genre.

Themes for English B recounts Scrimgeour's experiences teaching English at Salem State, a working class community college in Massachusetts. Like Lears in Edmundson's memoir, Scrimgeour seeks to be a border crosser, a teacher who can bring the intellectual rigor he derived from his Ivy League education to working class students, who have been denied access to such educations by the circumstances of their lives. Like Lears, Scrimgeour is at times successful and at times unsuccessful in his quest to get his student to think about new ideas and possibilities. 
In the character of his Socratic teaching persona, his narrative "I", Scrimgeour is similar to Lears, but in his method of understanding the working class community around him he is very different from Edmundson, who writes from the point of view of an insider who grew up in the working class community of which he writes, and closer to Diehl, an outsider, who uses careful research into the history of Luisa County to help her understand the world about which she writes. Similarly, Scrimgeour seeks to understand his students' current struggles by exploring the recent and not so recent history of Salem. The addition of history to teaching memoir is a practice that the extension of the genre to university presses seems to have enabled, since popular publications often don't seem to tolerate the patient, nuanced detail of history, and most of the earlier teaching memoirs published by popular presses include no history. The addition of history to memoirs about teaching also, perhaps, marks a self- conscious, post-structuralist awareness by bordercrossing teacher-writers that history has some capacity to mitigate the determinism and fixed assumptions about others that even the most open-minded teacher-writers fall prey to. Like the expansion of time in Edmundson's writing, the addition of history in Scrimgeour's and Diehl's writing, opens up the somewhat narrow--- at times even claustrophobic and solipsistic--- space of earlier teachers' memoirs. Interestingly, Edmundson's and Scrigmeour's motives for taking up teaching memoir are similar, and suggest why this genre might be so important to reinvigorating and reforming education as it is currently practiced in the United States. In his prologue, Edmundson reminds us that he has written his book, in part, "to give teachers who see their job as a combination of care and provocation a measure of encouragement at a time 
when many forces are trying to make them members of the service economy--people who provide skills, marketable knowledge, negotiable habits, but not inspiration, not the wherewithal to change a life around" (12). Similarly, remembering how his former teacher John Paul Eakin, a scholar of autobiography, encouraged him to develop his own graduate exam questions Scrimgeour says: "In this era of tests and accountability in education, when raising scores is the mark of educational success, John's idea establishes a different, bolder standard of educational rigor. If you get your working-class students to answer one more question right on a standardized test, you will have turned them into middle-class students. Congratulations. But will they remember any words that you have said, will they take them home and carry them for years, your sentences helping to shape their sentences, their world? Will they remember you, the way I will reminisce about John years from now, still referring to him, respectfully, as Mr. Eakin?” (67).

For both Edmundson and Scrimgeour, memoir becomes a way of writing about what we may soon loose sight of in our highly-standardized educational climate: inspired, self-reliant teaching. The romantic "I" of memoir--- in its ethical self-reliance and in its search for an authentic pedagogy---is ideally suited to challenging the shortcomings of highly bureaucratic, highly homogenized forms of education that undervalue individual vision and initiative. Like Edmundson and Scrimgeour, Christopher Lehmann-Haupt, in a 1969 book review of Lives of Children, recognizes teaching memoir's capacity to challenge the educational status quo. Calling Dennison's memoir “a profoundly revolutionary critique of the American technocracy" Lehmann-Haupt views Lives of Children as "an even-tempered but deeply indignant challenge to educationists who plan 
and run American primary schools as if rudimentary learning were a task, knowledge a category of consciousness, the brain an isolated organ, personal identity a series of compartments and people just so many machines" ("Store-Front Schools And the Good Life," NY Times). Edmundson's Teacher was published in 2002 and Scrimgeour's Themes For English B was published in 2006, but some of the forms of educational oppression that both these authors' challenge in their memoirs are not all that different from some of the forms of educational oppression that Dennison challenged forty years earlier in his account of an unusual elementary school.

Not surprisingly, given their different publishing history, the style of writing in Edmundson's Teacher and Scrimgeour's Themes for English B differs, with each book resembling a different strain of earlier teaching memoirs from the sixties and seventies. Teacher is funny, compelling, and reflective. One keeps reading the memoir to find out what Edmundson thinks and feels about education and the growth of his younger self, but also to be entertained by the vivid cast of characters who inhabit Medford high. In this sense, Teacher resembles Being With Children, in which Lopate uses the cast of characters in a school to create a serious memoir that also has much of the pleasures of a comic novel. Lopate has written about the importance of turning one's self-the narrative "I" of memoir - into a first-person character, into someone with distinctive characteristics that the reader is interested in reading about. In Being With Children, he does just that with his role as a teacher, and Edmundson, similarly, does just that with his role as student. In other words, not only do Edmundson and Lopate take memoir closer to the 
novel in their portrayal of a range of quirky characters, but they also take memoir closer to the novel in their portrayal of themselves - the "I" of the memoir - as characters.

Themes from English B is more earnest, angry, and essay-like than Teacher. One keeps reading the memoir to find out what Scrimgeour thinks of his students' lives and his own teaching, but also to be goaded by the recognition of social injustice and the hope that Scrimgeour will enlarge the possibilities open to his students. This is not to say that Themes from English B is boring, bleak, or humorless, but to say that it leans more towards teaching memoir as indignant essay than teaching memoir as novel, and in this tendency it resembles 36 Children, where one keeps reading to find out how Kohl will inspire his students, whose education has been mostly uninspiring. Here the narrative "I", is not so much a character, as in Lopate's and Edmundson's work, as a romantic consciousness, a reflective self, pitted against convention, such as is found in the autobiographical essays of Rousseau, Tolstoy, Emerson, and Thoreau.

\section{Crossing Borders of Language and Nationality}

Genres change when they add new topics to their repertoires or combine their repertoires with those of other genres. Teachers' memoirs about crossing borders of language and nationality follow the lead of earlier teachers' memoirs about crossing borders of race and class. They take up the perennial themes explored by earlier teacher writers -inspiration, self-reliance, failure, and poverty-yet they cross these themes with themes traditionally found in missionary and imperial biographies - questions about negotiating and translating languages, cultures, and identities abroad. To work, teachers' 
memoirs about crossing borders of language and nationality need the same kind of idealistic, yet vulnerable, narrator found in teachers' memoirs about crossing borders of race and class. Without a rich account of failure, an honest discussion of how inspiration falls short of action, teachers' memoirs, in general, and teachers' memoirs about working abroad, in particular, read like the most supercilious alumni notes, ticking off a list of accomplishments in exotic places.

Mark Salzman's Iron and Silk (1986), an account of time spent teaching English at a medical college and learning martial arts in China in 1982, often risks arrogance and obscures it narrator's vulnerabilities. The "I" of Iron and Silk is by and large always sure of himself, always certain of how to disentangle himself from any cross-cultural predicament, unlike the more tentative "I" of Salzman's later memoir about teaching writing in prison. More recently, Ian Klaus and Patrick Samway have used teaching memoir to recount experiences very much connected to current politics: teaching American history in Iraqu and setting up schools for Darfur Refugees. Klaus in Elvis is Titanic: Classroom Tales from the Other Iraq (2007) and Samway in Educating Darfur Refugees (2007) both remain closer than Salzman in Iron and Silk to the tradition of the vulnerable, idealistic narrator, which is essential to the appeal of teachers' memoirs. In classic teaching memoir form, Klaus's memoir ends with a failure, which is really a triumph: a Kurdish student accuses him of presenting America as a just society with an unblemished history, the opposite of what he, in fact, intended to do. Yet, the very fact that the student questioned him and challenged his authority, is, ironically, proof of the success of Klaus's methods. For Klaus, like most teacher-writers, the measure of Klaus' 
success is not his students' allegiance, but their capacity to embrace an intelligent and skeptical self-reliance. Samway, also in classic teaching memoir form, ends Educating Darfur Refugees with a failure that is a quiet triumph: when he leaves Darfur the schools he sought to build are not fully built, and the teachers he sought to train are not fully trained, yet he has started the ball rolling in a more promising direction. This same recognition of how reality relentlessly falls short of ideals, but does not mitigate the ongoing need for idealism and effort, is very much present in the sixties and seventies memoirs of teaching.

Like Diehl's Dream Not of Other Worlds and Scrimgeour's Themes for English B , Samway's Educating Darfur Refugees is a university press book, written by an English professor, again indicating the extent to which teachers' memoirs, as a genre has moved from the sixties and seventies world of the mainstream press and radical elementary school teachers to the world of university presses and English professors. Samway, unlike other English professors writing memoirs, is also a Jesuit, and his memoir, in some sense, updates and reinvents the missionary memoir at the same time that it takes teaching memoir out of the elementary school and into a more academic and international context.

Wai-Chee Dimock has described the fluidity of genres, how they spill and seep into each other, across significant stretches of time and space (75). One recent example of spill and seepage in the history of teachers' memoirs is the commingling of elements of teaching memoir with elements of missionary, travel, and imperial memoirs, in the work of Salzman, Klaus, and Samway. Another recent example of spill and seepage in the history of teachers' memoirs is the commingling of elements of teaching memoir with 
elements of the academic essay in the work of English professors, such as Diehl, Scrimgeour, Edmudson, and Samway.

Gayatri Chakravorty Spivak, in some of her talks and essays on training teachers and establishing schools in rural India, manages to draw on both these recent forms of spill and seepage in teaching memoir, these dual movements towards both travel narrative and academic essay. In Righting Wrongs-2002: Accessing Democracy among the Aboriginals, Spivak points out how American's working on human rights and poverty issues abroad should be aware of the hubris of helping others, and describes how she attempts to overcome such hubris and do meaningful work reforming Bengali schools. In reading Spivak's essay, we are a long way away, in terms of time and sensibility, from Ashton-Warner's Teacher, yet there again in the middle of the essay is a photograph of a student's writing, a call to those who work with poor and subaltern children to "learn how to learn from below," and a recognition of imagination's capacity to transform and redeem students' lives by subverting the system.

Between the publication of Ashton-Warner's Teacher in New Zealand in 1963 and Spivak's Righting Wrongs in 2008, more than forty years have passed, yet the core romantic ideals found in memoirs of teaching from the sixties - the power of the imagination, the embrace of humility, and the concern with freeing individuals from the limitations of poverty---originally articulated by Tolstoy and Ashton-Warner, remain compelling and unfulfilled, ensuring their reemergence in new and surprising locations, such as Spivak's meditation on "accessing democracy among the aboriginals". This recognition of the continuity of teaching memoir's themes in Ashton-Warner's and 
Spivak's work is not meant to suggest that we should conflate their thoughts on the reform of schools in rural, subaltern communities, but that we should recognize how genre allows for the transference of ideology, as well as form, across time and space, linking two writers, who are as different, as they are similar.

Spivak's accounts of establishing schools in rural West Bengal crosses teaching memoir with the academic essay, as well as with the narrative of development, not the narrative of development such as one would find in a World Bank Report, but the narrative of development, such as one would find in the accounts of educational reformers, such as W.E Du Bois, to whose earlier efforts at teacher training Spivak compares her own current efforts (49). Moving in a less academic, more popular direction, Greg Mortenson's Three Cups of Tea (2006), a first-person account of an American mountaineer's quest to build fifty-five schools for girls in rural Pakistan, like Spivak's work, crosses teaching memoir with the narrative of development, but here the narrative of development is not derived from W.E. Du Bois, but from National Geographic magazine, brining together earnest concern for less-able others with picturesque accounts of an "exotic" culture. As different as Spivak's and Mortenson's works are, they both demonstrate the capacity of teaching memoir to change and evolve as it moves from accounts of teaching classes at home to accounts of building schools abroad.

If you read enough memoirs of teachers who cross borders of race, class, language, and nationality you find your self asking why teachers writers seek lives where they are intentionally out of context, where they are momentarily or sometimes more 
permanently "other." Obviously, there is not any single answer to this question, but there can be a somewhat general recognition that, at their best, memoirs of border crossing chronicle teachers' attempts to make what Homi K. Bhabha refers to as "in between spaces," places where teachers and students question and sometimes even dissolve limiting and disabling "narratives of originary and initial subjectivities," replacing these stereotypical narratives with "strategies of selfhood — singular or communal— that initiate new signs of identity, and innovative sights of collaboration" (2).

The dissolution of "narratives of originary and initial subjectivities" seems to be the liberating agenda of many memoirs of teachers who cross borders, but the pursuit of a space in which to dissolve stereotypes often entails the inscription of stereotypes, if for no other reason than to make the narrative comprehensible to the reader, who is expecting to read about an encounter with "difference." In the introduction to this chapter, I pointed out that Tolstoy and Ashton-Warner often reify the very assumptions about poor children they seek to overturn, and that this irony of perpetuating injustices to redress injustices makes memoirs of teaching both a compelling and an impossible genre. Given this inherent duality in teachers' memoirs about border crossing, it seems impressive when teacher-writers do, in fact, provide us with credible glimpses of classes where, for a moment at least, poor and working class students, as well as their teachers, somehow free themselves from the identities bestowed by society, and imagine themselves in new and unpredictable ways.

By making border crossing seem significant, noble, and difficult memoirs of teaching from the sixties and seventies may have made it possible for organizations like 
Teach for America and City Year to readily recruit young teachers. These memoirs, in effect, created a compelling public narrative about the worth of border crossing, and testified to the value of well-educated young people teaching in urban schools, even if only for a short time. Although most contemporary participants in Teach for America and City Year probably have not read or even heard of the sixties and seventies memoirs of teaching they have probably been exposed to their narrative legacy: all the subsequent books and movies about teachers as border crossers. This narrative legacy, this story about how well-educated outsiders can improve urban schools, remains part of the tale we tell ourselves about effective educational reform. Whether we make this tale a reality depends on policy and history, but the fact that we even recognize this narrative about teachers as border crossers as potentially relevant to our current educational problems may, in part, stem from the widespread, yet not always immediately apparent, influence of teachers' memoirs from the sixties and seventies. 


\section{Chapter 3: Memoirs of Writing Instruction}

From Tolstoy's essay on teaching peasant children to write, Are the Peasant Children to Learn to Write from Us, or Are We to Learn from the Peasant Children, to Sam Swope's recent account of teaching writing in the Bronx, I'm a Pencil, memoirs of writing instruction recount self-reliant teaching, as practice and plot. In these memoirs, the personas become self-reliant teachers as they search for meaningful ways to teach writing in poor or socially marginalized communities. Finding traditional forms of writing instruction ineffective, the self-reliant teachers in these memoirs devise their own forms of writing instruction, rooted in their students' lives and communities. But these writing teachers do not stop at curriculum innovation, they go on to consider the positive as well as the harmful effects of their independent pedagogy.

In the introduction I described how Lawrence Buell views Emersonian selfreliance as a practice with three distinct stages: social critique, pursuit of personal liberation, and critical evaluation of one's strategies for personal liberation. For this cycle to be complete, for the subject to be engaged in a socially responsible form of selfreliance, the pursuit of individual liberation is balanced by the practice of self-criticism, as well as the practice of social criticism. In their search for meaningful writing 
instruction, the memoirists enact this entire three-part cycle of self-reliance. They pass through liberating moments - when they see how by an act of self-reliance they can free themselves and their students from stultifying forms of writing instruction — and critical moments - when they come to consider the consequences of their self- reliance for their students, as well as themselves. Some of the most moving passages in memoirs of writing instructions occur in this critical stage when teachers come to terms with the results of innovative practices. This honest recognition of the consequences of self-reliant teaching, its capacity to both help and to harm, enables teacher-writers to recognize the cost of "liberating" others. The forthright encounter with consequences, narrated in memoirs of writing instruction, suggests hard won insight and ongoing self-scrutiny. Self-reliant teaching, in this scenario, becomes then not so much a triumph of rugged individualism, as a continuous processes of self-examination.

This chapter traces self-reliant teaching as practice and plot in memoirs of writing instruction, at the same time that it seeks to highlight the historicity of memoirs about writing instruction. Many memoirs of writing instruction focus on teachers' recollections of teaching writing in poor communities. The roots of these recollections seem to be literary as well as personal, rooted in the teacher writers' classroom experiences and in their reading of other teacher writers' works. Many of the topics explored in Sylvia Ashton-Warner's and Herbert Kohl's accounts of teaching writing to children in poor communities can be found in Tolstoy's essays on teaching writing to children in poor communities. By the seventies there is a rich vocabulary of topics embedded in previously published memoirs of writing instruction, which teacher-writers, such as 
Philip Lopate and Keneth Koch, use to shape and interpret their own recollections of writing instruction. Then for three decades other types of teaching memoirs get published, but seemingly few or none of these memoirs focus primarily around the recollection of writing instruction. At the end of the $1990 \mathrm{~s}$ and the beginning of the $21^{\text {st }}$ century, however, memoirs focused on writing instruction begin to show up again, and the conventions first established in Tolstoy's essays and expanded in the work of AshtonWarner, Kohl, Lopate, and Koch resurface in the work of Erin Gruwell, Sam Swope, and Mark Salzman. When teachers write memoirs of writing instruction they appear to be remembering personal history and literary history: their own experiences, as well as previous teacher-writers' representations of comparable experiences.

\section{Other Times, Other Continents: The Country Schoolmaster or Yasnaya Polyana}

In 1861, having returned from Europe where he was influenced by educationminded writers, such as Rousseau, Froebel, and Pestalozzi, Tolstoy published an educational magazine titled, The Country Schoolmaster, but commonly known as Yasnaya Polyana, after the estate on which he ran a school for peasant children. In Yasana Polyana Tolstoy published a brief memoir-like article on teaching writing to peasant children, which was later anthologized in many complete editions of his works. The title of Tolstoy's article aptly summarizes the undercurrents of exploration, revelation, and self-doubt that often seem to characterize teachers' recollections of teaching writing in poor communities: Are the Peasant Children to Learn to Write from Us, or Are We to Learn from the Peasant Children? (25). 
In good romantic fashion, Tolstoy's title suggests that poor children have a form of vital, authentic knowledge that more prosperous, educated adults have lost, that teachers of writing in non-mainstream communities can learn as much from their students as they can teach them. This stance, with it's simultaneous idealization of others and it's genuine recognition of the very real strengths and capacities of others, will reappear again and again in memoirs about teaching writing in poor communities. With the words "peasant children" updated to "urban children," or any of the other contemporary terms used to describe children living in poor communities, Tolstoy's title could be the subtitle of any number of current memoirs about writing instruction.

Tolstoy opens his memoir-like essay by describing his search for a way to teach writing that would be meaningful and relevant to the children in his classroom. He starts out using standard approaches to teaching composition, but realizes that the students "did not understand the main thing, which was why they should write and what good there is in writing" (25). He attempts to solve this problem by giving the students different themes, but that doesn't make the students anymore interested or engaged in the processes of writing. Then, almost through serendipity, he stumbles on a method of instruction, which works. He introduces the students to something he himself enjoys doing, a sort of game with proverbs, in which a proverb is used as the inspiration for the creation of a story or a scene. Tolstoy emphasizes that he did not plan this as a pedagogical strategy, but simply stumbled upon it by luck when he brought to class a copy of Snegirev's collected proverbs, which he had been reading the night before. 
Opening Snegirev's collected proverbs, Tolstoy reads a proverb to his class: "He feeds with the spoon, then pokes the eye with the handle". Instead of asking the students to interpret the proverb, Tolstoy explains how the proverb suggests a story: a peasant takes a beggar into his home, and then begins to rebuke him for the good he has done him. Tolstoy challenges his students to write such a story, and when none of them know how to begin he starts to write the story, with input from the most eager students, who eventually take over the composition of the story.

I describe, at length, Tolstoy's search for a meaningful way to teach writing, because the sixties and seventies memoirists engage in a comparable search. In a process that resembles the three stages of self-reliance, the memoirists reject standard methods of teaching writing because they seem irrelevant, develop their own more child-centered, more biographical methods of teaching writing, and critique the results of such initiative. Like Tolstoy, the memoirists lend students aspects of their own identity as writers, in an act that can be read as both a form of manipulative projection and as a form of creative freedom. They encourage their students to write memoirs, like themselves. Similarly, the proverbs Tolstoy offers his peasant students for inspiration are proverbs related to peasant life, and the writing the students produce in response to the proverbs draws on their memories of village life.

Tolstoy's emphasis on the serendipitous nature of his solution to his teaching problem---the fact that he just happened to bring to class a book of proverbs he was eagerly reading---is also typical of later teachers writers' accounts of the search for meaningful ways to teach writing. Beneath the rather ingenuous claim to have just 
mistakenly brought the right book to class, is a more profound recognition: that what inspires teachers often has more power to inspire students than the exercises that are specifically designed for students alone. It seems significant that it is something meaningful from the teacher's own life as a reader and writer-a book of proverbs---that provides the means of devising meaningful writing instruction.

Again and again, teachers after Tolstoy will describe how they are able to make their writing instruction more meaningful when they bring to class the literature that inspires their own writing. Teachers' memoirs, in general, can be seen as one long testimony to the belief that what interests individual teachers interests their students. In an essay titled Education and Culture Tolstoy acknowledges the reciprocity between teacher interest and student interest, which runs through teachers' memoirs as a genre: If you wish to educate the children by science, love your science and know it, and your students will love both you and the science, and you will educate them; but if you yourself do not love it, the science will have no educational influence, no matter how much you may compel them to learn it (Tolstoy, 149).

From this point of view, voiced repeatedly in teachers' memoirs, student engagement depends on teacher engagement, and the privileging of teacher interest, inherent in selfreliant teaching, becomes a public necessity, rather than an individual indulgence.

Memoir, in some sense, can be read as a genre preoccupied with the search for an authentic self, and teachers' memoirs can, likewise, be read as a version of memoir preoccupied with the search for authentic pedagogy. This statement assumes a conflation of identity and pedagogy in the intersection of memoir as a genre and teaching memoir as a particular version of memoir. In so far as "authenticity" is always elusive and always 
paradoxically constructed, both the search for authentic identity and the search for authentic pedagogy are ongoing, incomplete processes without closure. However, there are moments in teachers' memoirs when teacher writers unite their identities as teachers and their identities as writers, and the search for both authentic identity and authentic pedagogy seem to be momentarily fulfilled. Tolstoy's description of how he learned to teach writing meaningfully by allowing students to imagine themselves as writers like himself is just such a moment, a moment in which Tolstoy embodies his double identity as both a teacher and writer.

The proverb Tolstoy chooses to inspire his students--“He feeds with the spoon, then pokes the eye with the handle"-is in itself interesting for the ambivalence it expresses about the ethics of helping others, particularly others who are less powerful or fortunate than one self. The proverb implies that helping others and abusing others may not be as far apart as we would like to think, and that the two can become interchangeable. A very similar ambivalence about teaching poor children to write in ways that call on them to take on the identities of the adult writers who are their teachers runs throughout teaching memoirs about writing. The teachers in these memoirs recognize that when they lend their own writing identities to poor children they are giving them a very powerful gift, a gift that allows them access to some of the agency which they have been denied, but a gift that may stir up emotions and ideas that the children are too young and inexperienced to manage. Writing creatively and honestly, like their teachers, may free the children to speak in their own voices, to construct more authentic identities, but it may also lead them, for better or worse, to want what they do not have, to 
unleash their anger at an unjust society, to think about things we try to shelter children from.

In a passage remarkable for its recognition of both the problematic and liberating power inherent in the gift of meaningful writing instruction, Tolstoy expresses ambivalence about his own success as a teacher of writing that can be heard, in comparable forms in the work of the sixties and seventies memoirists:

I dimly felt as if I were surreptitiously watching a beehive behind glass, in which the work of the bees was concealed from mortal eyes. It seemed to me that I had corrupted the pure, primitive soul of a peasant boy. I dimly felt something like remorse for an act of sacrilege I had committed. I thought of those children, before whom idle and debauched old men cavort and to whom they show lewd pictures in order to titillate their weary and worn-out imaginations, but at the same time I was ecstatic, happy as a man who has seen something no one has seen before.

For a long time I was unable to account for this impression, though I felt that it was one that teaches a mature person something, leading him to a new stage of life, making him renounce the old and devote himself to the new. Even the next day I could not make myself believe my experience. It seemed strange to me that a half-literate peasant boy should suddenly arrive at such conscious artistic powers - powers that Goethe, for all his immeasurable achievements, was unable to equal. It seemed strange and offensive to me that I, the author of Childhood, who had garnered some success and earned recognition for artistic talent from a cultivated Russian public - that I, in the matter of art, should be unable to teach anything to eleven year old Semka or Fedka, or to help them in any way, but that only with difficulty and in a happy moment of excitement should I be able to follow them or understand them. All that seemed so strange to me that I could not believe what had happened to me on the previous day. (32)

Here inspiring writing instruction, which bestows the teacher's identity as a writer on the students themselves, is much more than simple instruction. Identity, sexuality, jealousy, Romantic notions of childhood, class anxiety, and religious-like revelation all come together in a reflection of what happens when a teacher encourages poor children to write creatively. The exact words and terminology will change in the work of the sixties and 
seventies memoirists, but in only slightly different form the same heady mixture of contradictory thoughts will arise when the memoirists reflect on the effects of their creative writing instruction.

I have considered how two of Tolstoy's topics - the search for meaningful writing instruction, and reflection on the ambivalent gift of such instruction-appear in the work of the memoirists. Two other conventions, initiated by Tolstoy, also appear in the work of the memoirists: embedding the publication of student writing in the publication of the teacher's writing, producing a portrait of an accomplished or in some way singular student writer. Both of these topics construct students' identities as writers, in ways that are entwined with the teacher-writer's own identity. Turning first to the convention of embedding students' writing in the teacher's writing, we can see how Tolstoy uses much of his essay-like memoir on writing instruction to reproduce two stories written by two students, Fedka and Semka. Tolstoy retells Fedka's and Semka’s stories, “They Feed With a Spoon, Then Poke the Eye With a Handle" and "The Life of a Soldier's Wife" in vivid detail, at the same time that he provides a highly appreciative analysis of the stories literary merits. Very efficiently, within the context of Tolstoy's own work, Fedka and Semka, are presented as authors worthy of the reader's serious attention.

What does this embedding of student writing in a teacher's writing tell us about the rhetorical purpose of teaching memoirs, and teaching memoirs relationship to memoir and autobiography? These are two separate, but related questions. The embedding of student writing in teachers' writing suggests that part of the rhetorical function of memoirs of teaching is to free and enable other's voices by lending them the power 
inherent in one's own voice: students from communities traditionally denied sufficient access to literary publication are able to publish their writing because their teacher extends to them the power he or she has to publish writing. This seems like a small gesture, but it is significant in so far as it advances the democratic ideal of a community in which multiple voices are heard. More than issues of social justice, however, appear to be at stake in the embedding of student writing in teacher's writing. By association with the students' writing, the teacher's writing gains a sense of freshness, directness, and urgency. By association with the teacher's writing, the students' writing gains a sense of legitimacy and authority. Co-opting or enabling, manipulative or freeing, Tolstoy's choice to represent Fedka's and Semka's work within the context of his own work, initiates a convention in memoirs of teaching, which will be repeated by many later teacher writers who publish or describe their students' writing in their own writing.

It is worth asking how the student writing embedded in teacher writing expands the formal and thematic possibilities of memoir. Publishing their writing together, the memoirists' and the students' identities as writers depend on the presence of each other's work. Tolstoy initiates a convention in teaching memoir - the embedding of student writing in teacher writing - that expands the narrative capacity of teachers' memoirs, that enables teacher writers to more fully use the story of the self to illuminate the story of others.

The noteworthy student writing included in teachers' memoirs is usually the work of a precocious writer. Tolstoy describes at length the development of Fedka as an accomplished writer, emphasizing his artistry, as well as the vividness with which he 
describes peasant life. In their portraits of singular student writers, the memoirists also focus on both students' artistry and their capacity to vividly convey the details of the poor and/or subaltern communities in which they live. There seems to be a lot going on in these portraits of singular student writers. As doubles and projections, the students featured in the portraits help teachers explore their own identities as writers, but the students are also very much portrayed as significant writers in their own right. The emphasis placed in teachers' memoirs on student writers' capacity to write movingly about the poor and/or subaltern communities in which they live romanticizes others, at the same time that it genuinely celebrates some children's remarkable ability to narrate their own lives, and find agency where agency has been denied.

Wai-Chee Dimock has recognized the ways in which genres often overflow the bounds of time and space, moving between continents and time periods (75). Reading recent teaching memoirs about writing in the light of Tolstoy's essays on the school at Yasna Polyana highlights just such distant connections between texts. Two topics, which first appear in Tolstoy's work - the search for meaningful writing instruction and ambivalent feelings about the power of meaningful writing instruction-recur repeatedly in the writing of later teacher writers in other times and places. Two conventions, which first appear in Tolstoy's work - the embedding of student writing in the teacher's writing and the portrait of the singular student writer-likewise recur repeatedly in the writing of later teacher writers in other times and places. The two topics, oriented towards designing and reflecting on instruction, and the two conventions, oriented towards showcasing/narrating the work of students, seem to grow out of the actual circumstances 
of devoted teachers lives: their genuine need to develop curriculum that matters to their students and their recognition that their students are remarkable and worthy of celebration. Yet as rooted as these topics and conventions are in the actual circumstances of devoted teachers' lives they also have literary precedents in the topics and conventions of memoir. The search for authentic, meaningful curriculum in teaching memoir mirrors and extends to a new context the search for an authentic, meaningful self in memoir. In their tenderness and bemused scrutiny, the carefully rendered portraits of singular students in memoirs of teaching resemble the carefully rendered portrait's of writers' childhood selves in memoirs of youth.

\section{The Sixties: Teacher and 36 Children}

Memoirs of teaching weave together personal memories of a teacher's own class and literary memoirs of other teachers' classes. If as Sven Birkets points out memoirs are "pledged not to an ostensibly detached accounting of events but the presentation of life as it is narratively reconstituted by memory" then teaching memoirs might be said to be pledged to the presentation of instruction as it is narratively reconstituted by the teacher's memory of their actual classes, as well as their literary memory of the classes of previous teachers described in books (23). Teachers memories of their own teaching and their memory of other teachers teaching weave in and out of each other, intersecting, overlapping, and colliding, to create new patterns and possibilities that enlarge the breadth of both personal recollection and instruction. 
Ashton-Warner opens Teacher, published in 1963, not with the personal memory of her own class at Pipiriki, but with the memory of Tolstoy's class at Yasnaya Polyana, almost a century earlier. She presents Tolstoy as a model for the type of child-centered, constructivist teacher she wishes to become, and argues that her "organic" methods of teaching reading and writing has precedents in Tolstoy's classroom (29). Ashton-Warner then quotes the classroom recollection of a student of Tolstoy's, Basil Borosov, which is later also quoted by George Dennison in the conclusion of the Lives of Children (Warner 30) (Dennison 281-282). By invoking Tolstoy, Ashton-Warner lends legitimacy and authority to her innovative pedagogy, and connects literary memory and personal memory, transposing the recollection of Tolstoy's class on top of the recollection of her class to create a kind of pedagogical palimpsest, in which one teacher's instruction and writing is visible beneath another's.

Like Tolstoy, Ashton-Warner passes through three stages of self-reliant teaching: rejecting the standard reading and writing curriculum as irrelevant to her students, developing her own, more meaningful reading and writing curriculum, and finally reflecting on the ambivalent consequences of replacing an inauthentic method of instruction with a more authentic one. This processes of critique, innovation, and scrutiny is not uncommon for devoted teachers, and is sometimes called teacher inquiry, yet in the context of memoirs about teaching it reoccurs in enough texts to take on the status of a literary convention — the classic plot — so to speak of memoirs about teaching. As they move through these three stages of self-reliant teaching - critique, innovation, and scrutiny---teacher writers search for authentic instruction, just as writers of memoir 
proper appear to search for an authentic life or at least an authentic story about their life as they examine, reinterpret, and reflect on their past. Rejecting conventional instruction, creating one's own instruction, and considering the outcomes of such actions involves the same risk-taking and shedding of societal constraints that the search for an authentic self in memoir proper does, and can be seen as yet another iteration of this search.

In the chapter on memoirs of educational injustice, we saw how Ashton-Warner rejected the standard curriculum because it alienated her Maori students and did not address their real needs as readers and writers. In particular, she was concerned that the student reader, based on the sanitized experiences of English and American children, was meaningless to her students, who needed texts that "bridged" their life in the Maori Pa and their lives in English-speaking schools. Unable to find such texts, Ashton-Warner devised what she called "organic" reading and writing, in which students use their own autobiographical writing as reading material. In essence, Ashton-Warner, helps her students become writers of memoirs, like herself. As the writer of an autobiography, an autobiographical novel, and a teaching memoir, Ashton-Warner was obviously an author who found personal narrative compelling, and it is easy to see how her own interest in personal narrative as a writer, as much as any pedagogical consideration, lead to her recognition that the reading and writing of memoir by young children could produce the "bridge" between Maori and English-speaking worlds that she was seeking for her students. Memoir becomes for her students, and to an extent for herself, a tool for navigating bicultural identities. Like Tolstoy with his beloved proverbs, Ashton-Warner 
finds the solution to her instructional problems in the decision to share with her students what animates her own writing life.

Having searched for and found a meaningful way to teach writing, Ashton-

Warner, like Tolstoy reflects on the complex consequences of her instruction:

This afternoon marks the beginning of composition. Word Composition. Writing. The first wall between one liver and another. Putting thoughts in writing for the other instead of the direct route of speech or touch. I'm both gratified and sad. Talkers and touchers are never lonely but writers are. Here is the beginning of loneliness. Should I be glad because my children are voluntarily composing sentences for the first time? One Twinnie is writing on the blackboard about the story: "The fish is jumped. The fish is swimming. The little fish is in the sea. The fish he have no leg." Ah well I can't stop civilization. A picture springs into the world behind my eyes of a Maori marae of the past with the tattooed, impassioned speakers. The direct vital communication at all times. (117) Tolstoy, in the striking passage about bees behind glass, contemplates the turmoil of feelings that watching Fedka and Semka write well evokes in him. Ashton-Warner likewise describes a turmoil of feeling when she watches Twinnie and her other young students begin to write. Tolstoy's turmoil is different than Ashton-Warner's, more rooted in a mixture of sexuality, jealousy, and awe, yet both of their powerful reactions to successful student writing seem to stem from vertiginous moments of fused identity, where the boundaries between themselves as writers and their students as writers seem to blur. Both Tolstoy and Ashton-Warner are proud of the meaningful writing instruction they have devised, but both also seem to believe that their instruction has initiated a loss of innocence, that by learning to write their students have gained access to adult-like forms of power and agency, which can seem overwhelming or alienating in the context of childhood. 
Ashton-Warner's description of watching Twinnie and the other young students learn to write has a remarkable symmetry, a carefully balanced counterpoint, where the recognition of writing's capacity to isolate writers in the first half of the paragraph is matched by a recognition of writing's capacity to unite cultures in the second half of the paragraph. Ashton-Warner starts out by emphasizing how becoming a writer isolates one from more direct forms of social communication, such as speech and touch. Even though she is talking about the isolation of student writers, her words imply that she herself as a writer knows these forms of isolation and loneliness first hand. Then, just when the paragraph seems about to sink into maudlin self-pity, Ashton-Warner turns it around with a crisp question about whether learning to write is simply a good thing. Following this question is a description of a child writing about a fish, a description that leads AshtonWarner to envision speakers in a traditional Maori marae, a temple enclosure for sacred ceremonies. Like Tolstoy with his bees behind glass, Ashton-Warner's choice of figurative language suggests that reading student writing is giving her access to something enclosed and hidden, to the consciousness or essence of others that is not commonly displayed. At one level, this passage, in which a child's writing is compared to the sacred speech of his ancestors, is just an example of reductive, colonial romanticism, but at another level the passage neatly illustrates how writing, even the writing of children, can open up lines of communication between cultures, can lead a person from one culture to imagine the history of a person from another culture.

The last sentence of the passage on Twinnie writing --"the direct vital communication at all times"-implies that the loneliness and isolation that Ashton- 
Warner initially attributes to all writers, including her students and her self, may, in retrospect, be a cultural problem only of Western writers such as herself, that her Maori students because of their more vibrant culture will maintain the "direct, vital connection" even in the disconnected act of writing. Again this can be dismissed as reductive, colonial romanticism, but there is something more here. To begin with there is Ashton-Warner's capacity to change her initial assumptions of how becoming a writer affects one's life, her willingness, gained through observing her students, to entertain the notion that some of the costs that we attribute to the writing life, the indirectness of writing as a form of communication, may be culturally-bound, not inherent to the act of writing itself. I am less concerned with whether Ashton-Warner's observation is true or not than with the fact that it is made in the context of a teacher contemplating the consequences of meaningful writing instruction, and the jumble of emotions involved in watching students write. Such moments of identification between teachers and student writers seem central to the emotional landscape of memoirs about teaching writing.

Besides the two intertwined topics initiated by Tolstoy--the search for meaningful writing instruction and the reflection on its consequences-Ashton-Warner takes up the two conventions initiated by Tolstoy - the embedding of student writing in the teacher's writing and the portrait of the singular student writer. To these two conventions, concerned with constructing students' identities as writers, Ashton-Warner and Robert Gottleib, her editor, add a third: photographs of Maori students' written work and photographs of Maori students' writing. What is striking about the photos of the young Maori authors in Ashton-Warner's Teacher is that they are not seemingly exploitative 
and derogatory, that they evoke a sense of the other — the child from elsewhere - not as fascinating and pitiful, but as familiar and deeply admirable in the concentration with which they write.

In a one-page presentation of student writing, there are photos of students' finished writing and two pictures, in opposite corners, of a girl and a boy at their desks leaning over their papers, intent on their writing, while the hubbub of the classroom swirls around them (53). The student writing presented on the page is violent and intense, not what we would necessarily expect from children writing at school : "I got drowned," "Mummies got a hiding off Daddy. He was drunk. She was crying," "Manny’s in the coffin under the ground," "I went to the river and I kissed Lilly and I ran away. Then I kissed Philliaa Then I ran away and went for a swim," "Our baby is dead. She was dead on Monday night. When mummie got it" (53).

It is a remarkable page, and like so much in Ashton-Warner's work it is wonderfully hard to know what to make of it. Should we be impressed, shocked, or transformed by our recognition of the raw honesty of students' thoughts and feelings? Should we see the intensity of the writing as unique to this particular classroom or as latent and repressed in all classrooms? Ashton-Warner doesn't give us any easy answers to these questions, but with the placement, in opposite corners of the page, of two photos of children intently writing, Robert Gottleib, the editor of Teacher, assures that we take these questions seriously, and consider the possibility that instruction in memoir writing is unnervingly powerful and potentially psychologically redemptive for children living in difficult social contexts. This would come across as a patronizing, reductive 
observation - a condescending pop-psychology prescription for those less fortunate-if Ashton-Warner herself wasn't engaged in just such an endeavor in the writing of Teacher and her other autobiographical works. We are encouraged to imagine the subjects of the two photos, the boy and girl, not as exotic, but as like Ashton-Warner, like our own students, like ourselves, preoccupied with the work of narrating our lives.

Cathryn McConaghy has pointed out that Ashton-Warner's intimate narratives make the "neuroses, fantasies, longings, crisis, affirmations and rejections" of the teacher working in difficult social contexts accessible, that her writing "testifies to teaching as a form of consolation and survival" (68). I would like to extend this observation to suggest that Ashton-Warner treats writing instruction, particularly instruction in the production of memoir, as a form of consolation and survival for herself and her students. The portrayal of writing instruction as a form of consolation and survival, for teacher and student, has precedents in the essays and diaries of Tolstoy, which Ashton-Warner seems to have read, but it takes the work of Ashton-Warner herself to bring the representation of autobiographical forms or writing instruction as socially and psychically redemptive into the $20^{\text {th }}$ century.

In addition to owing something to Tolstoy, Ashton-Warner's portrayal of creative writing instruction as redemptive seems to owe something to Emerson. The way she draws a connection between students' creative writing and the development of their selfreliance seems both Emersonian and highly self-reflexive, as the same connection could seemingly be made between her own writing and her teaching: 
The whole exercise of creative writing, the reaching back into the mind for something to say, nurtures the organic idea and exercises the inner eye; and it is this calling on the child's own resources that preserves and protracts a little longer his own true personality. (55)

The exercising of "the inner eye," the "calling on the child's own resources," the preservation and protaction a "true personality," destined to be eventually altered and distorted by the mores of social life, suggest that creative writing instruction fosters the development of a self-reliant, Emersonian self.

In a recent interview, Herbert Kohl, has explained that he was very much influenced by Ashton-Warner's representation of autobiographical forms of writing instruction as socially and psychically redemptive:

I really liked the whole notion (that is not unique to her) of the idea of eliciting primary vocabulary from the students themselves and building literacy in some substantial way out of their own worlds and their own experiences and their own needs and concerns... The approach resonated with me primarily because it was a way to reach through past barriers, to enable literacy for poor people that the economic system gives rise to. (Connor and Radford, 164)

Kohl goes on to elaborate on this point, reminding us that Ashton-Warner's emphasis on autobiographical writing and reading provided students with "the capacity to develop a literate memory" (165). When asked how Ashton-Warner's work has influenced his own work, Kohl calls himself a "translator" of her work. How then does Kohl's 36 Children translate Ashton-Warner's portrayal of writing instruction as a form of consolation and survival? How does Kohl reinterpret the central topics - the search for meaningful writing instruction and the reflection on it consequences - explored by Tolstoy and Ashton-Warner? How does Kohl rework the significant conventions - the embedding of student writing in teacher writing and the portrait of the singular student — found in 
Tolstoy and Ashton-Warner's work? With the publication of 36 Children it is possible to glimpse the emergence of a literary history for memoirs of writing instruction, stretching back from the work of the New York writers involved in the Teacher and Writer's Collective to the work of Ashton-Warner and Tolstoy.

Like Tolstoy and Ashton-Warner, but in the urban context of a Harlem public school, rather than a rural context, Kohl finds himself involved in the processes of searching for a meaningful way to teach writing. In the self-reliant manner of Tolstoy and Ashton-Warner, Kohl rejects, as stultifying and irrelevant, the standard curriculum, which he is ostensibly expected to teach. Instead, he begins, like Ashton-Warner, by having students write about their lives. After assigning a homework assignment about the Harlem streets on which they live, he interests the students in writing their own modern versions of classical myths, as well as a class magazine and books of their own choosing, which range from memoirs to sci-fi novels.

As a result of his self-reliant teaching, Kohl's students become forthright chroniclers of their urban world, leaving him, like Tolstoy and Ashton-Warner before him, to reflect on the ambivalent consequences of teaching children to write powerfully and authentically. He describes another teacher's reaction to the violent content of the class magazine:

"I just read your magazine. It was really interesting, children. Robert Jackson, you really draw beautifully, only Robert, why do you draw so much violence - child, your imagination needs to rest. Children, I don't understand why you talk of much fighting and stabbing. You can't possibly know about that. Tell me now, who knows what a junkie is? See I told you no one knows. Newspapers and magazines aren't for that type of nonsense" (154). 
In presenting this teacher's criticism of his class's magazine, Kohl acknowledges that he has, in his pursuit of authentic writing instruction, encouraged his students to be honest and knowing in a way that might be upsetting to adults who hold different expectations of children. Questions of race, class, privilege, defiance, pride, guilt, and shame all swirl together in this passage, which has the same raw honesty as Tolstoy's bees behind glass and Ashton-Warner's little fish. All three passages are conflicted reflections on the consequences of searching for meaningful writing instruction.

Thomas Larson points out that "be it abuse, death, grief, a fall off a horse or the rise to the presidency, a memoir is, as tale and as discovery, always consequential, even if one tries narratively to evade or delay the consequences" (45). Similarly, teachers' memoirs are always consequential, but the consequences reflected on are the result of instructional decisions and curricular choices, rather than life decisions and choices. As is evident from the bee, fish, and magazine passages in Tolstoy's, Ashton-Warner's and Kohl's work, these moments of reflection on the consequences of instruction are often places where teaching memoirs become most vivid and interesting, where there is a true effort to understand the self's relation to others. Thomas Larson suggests that in effective literary memoirs "narrative and reflection interbreed and conflict in birthing that which is wholly new" (54). Likewise in memoirs of teaching, in general, and memoirs about writing, in particular, narratives about the search for meaningful instruction and reflection on the ambivalent consequences of meaningful instruction intersect in ways that complicate and enliven the best writers' work. 
Kohl takes the embedding of student writing in teacher writing and the profile of the singular students in directions that extend the work of Tolstoy and Ashton-Warner. Tolstoy provides extensive, carefully detailed descriptions of student writing; AshtonWarner includes snippets and photos of student writing in her writing; Kohl devotes whole sections of his memoir to student writing, greatly expanding the amount of actual student writing displayed in a memoir of teaching. Approximately ninety pages of Kohl's 224 page memoir consists of student writing, including a complete student novel and class magazine. This decision to include multiple examples of student writing in full form, rather than in descriptions and snippets, changes the orientation of memoirs about teaching from a focus on teacher development to a more joint focus on teacher and student development.

Kohl extends, over time, the portrait of the singular student writer, found in Tolstoy and Ashton-Warner. He gives us not only portraits of two remarkable child writers, Robert and Alvin, and extensive examples of their work, but also an afterward titled, A Dream Deferred, in which he tells about how they later became alienated from school, and unsure of their future. By adding reflections on Robert and Alvin's subsequent circumstances to portraits of their past promise Kohl testifies to our society's incapacity to support the aspirations of talented urban students. The portrait of singular student writers, which in Tolstoy and Ashton-Warner, vividly brought the poignancy and promise of individual children to life, acquires through Kohl's juxtaposition of the past and the present a greater political urgency. With the reflection on singular student writers at different points in time, Kohl turns the sometimes sentimental portrait of singular 
student writers, found in Tolstoy and Ashton-Warner, into a form of prophetic witness, intended to elicit our indignation and desire for change.

With Kohl's 36 Children memoirs of teaching begin to take on a more coherent form, organized around the school year. Tolstoy's essay-like memoir loosely links memories by topic, subject matter, and association. Ashton-Warner uses this same loosely linked form, dividing her memoir between a section on instructional topics, and a collection of memories from nine years of teaching. Kohl, in contrasts, builds his narrative around the school year, with the addition of an afterward that covers his own and his students' subsequent lives. Another teaching memoir published in 1964, Jonathan Kozol's Death at an Early Age, is also built around the school year. This emergence of the school year as an organizing device in teaching memoir seems to mark a kind of maturation of the genre, a tidying up and a packaging of what had been a more random and idiosyncratic kind of writing. The school year, with its definite beginning, middle, and end, allows for a discernable narrative progression, a more clearly told tale of experience gained, in which the ways that a teacher and students have changed are easily recognizable. When one finishes 36 Children, one knows that the slightly naïve teacher we meet in the opening pages, in September, is a very different person than the more experienced teacher we meet in the closing pages, in June.

Earlier I spoke of how writing instruction is often represented as a form of consolation and survival, for both teachers and students, in teachers' memoirs. The types of consolation associated with writing instruction, however, differ in Tolstoy's, AshtonWarner's, and Kohl's works: in Tolstoy the consolation is largely aesthetic, based on the 
recognition of students as talented authors; in Ashton-Warner it is primarily therapeutic, based on the recognition of students as insightful interpreters of their own psychic dramas; in Kohl it is primarily political, based on the recognition of students as witnesses with socially significant testimony to share. These three possibilities inherent in writing instruction - the consolation of aesthetics, therapy, and politics - become the cornerstones of memoirs about writing instruction, to which many future writers of such memoirs return, consciously or unconsciously, borrowing and combing all three outlooks in new and different ways.

\section{The Seventies: Being With Children and Wishes, Lies, and Dreams}

Philip Lopate's Being With Children was published in 1975, eight years after 36 Children. Lopate seems to have had a clear vision of his teaching memoir as part of an earlier literary tradition. In a 1989 afterward to a republished edition of Being With Children, Lopate explains that "Being With Children was meant to be viewed in the same line of autobiographical educational accounts as those predecessors who had been inspirational to me: Herbert Kohl, Sylvia Ashton-Warner, John Holt, James Herndon, Jonathan Kozol, and George Dennison" (400). Clearly aware, that in writing a memoir of his own teaching, he is also writing a memoir of previous memoirs of teaching, Lopate makes the memoir of teaching into a more openly literary form than his predecessors.

Lopate's self-conscious prose, his awareness of himself as a writer working in a particular tradition, allows him to use reflection to side step sentimentality. Authors of previously published memoirs of teaching reflected on their teaching. Lopate reflects on 
his teaching and also on how he writes about his teaching. Such layered reflection, on both life and art, enables Lopate to speak movingly and authentically about scenes in memoirs of teaching that have become clichés. One such scene is the ending of memoirs about teaching, where the teacher departs in high dudgeon-either dismissed or voluntarily exiled. Aware of this tradition and the potential for the end of memoirs about teaching to be mired in sentimentality, Lopate creates an ending steeped in layered reflection on both the ends of other memoirs and the end of his own teaching:

Almost all books on personal teaching experiences gravitate toward leaving. The teacher is discovered doing things that raise the ire of a certain part of the community; his fraternizing with students provokes gossip; the principal will not renew his contract; or the grant runs out; he leaves sadder and more prepared, perhaps to try some where else where the air is freer.

God protect me, I am still hanging on. The tragedy has not yet struck. If the lack of a denouement leaves this book incomplete, I accept the dramaturgic flaw. My prayer is to stay at P.S. 90 for as long as possible. Don't even ask me to predict when that will be. With so much that is constantly being ripped away from us, please, let me hold onto this life a little longer. (331)

Without the self-conscious reflection on the ends of other memoirs of teaching in the first paragraph the earnest emotion in the second paragraph would seem maudlin: the memory of other memoirs frames Lopate's memories. With the publication of Being With Children, memoirs of teaching have matured to a point where they can be viewed as distinctive genre with a literary history, which a teacher writer can use to interpret their own personal history.

Lopate repeatedly juxtaposes these two histories, literary and personal. He uses the distinctions between literary and personal history to stake out his own territory and highlight the ways he is unique as a teacher, writer, and a person: 
It interests me that in some other written accounts of teaching experiences, the involvement with the kids seems to coincide with the author's decision to marry and raise a family. Herbert Kohl's 36 Children and George Dennison's The Lives of Children both end with their heroes getting married. James Herndon was already married when he went through the experiences in The Way It Spozed to Be. With these writers their commitment to communitas naturally leads to the mature task of building a family, of making a harmony between work and personal life. I can't say the same for myself. My personal life was anything but harmonious. All those sober, responsible, root-taking attitudes had been transferred over to my job, which in effect I had married. (89)

Here teaching memoir is represented as a subgenre that chronicles a particular kind of male maturation, in which the teacher's movement from isolation to community in the classroom mirrors and enables his movement from isolation to community in his personal life. To break with this tradition, as Lopate suggests he does, leads to a recognition that teachers' memoirs do present a script of sorts, a set of guidelines for a particular form of personal redemption and growth, that may not be viable for everyone, or may need to be rewritten to avoid the pitfalls of cliché.

Given his tendency to juxtapose personal and literary history, and his awareness of teaching memoir as a coherent genre it is not surprising that Lopate uses humor and self-mockery to reinvigorate the central topics tackled by Tolstoy, Ashton-Warner, and Kohl. The search for meaningful writing instruction and the reflection on the ambivalent consequences of such instruction was in Tolstoy's, Ashton-Warner's, and Kohl's memoirs a fairly earnest pursuit, but in Lopate's memoir the same topics are leavened with a sense of absurdity and mild irony. Trying to find writing assignments for disinterested students, Lopate becomes comically obsessed with generating new topics for students to write about: "I would be riding the bus to school thinking lesson A, B, C, D? or M? Suddenly I decided it has to be G, G, G...!” (44). Tired of generating an 
endless smorgasbord of topics, Lopate decides instead to let the students write their own play about classroom life. The students' play parodies life at PS 90 and turns out to involve a student as a flying angel, suspended by a rickety flying device, which, in good slapstick fashion, takes a great deal of time to rig and construct, leaving Lopate to reflect on how he has managed to place himself and his class in such an absurd yet wonderful situation.

In terms of the history of memoirs of teaching, two things are noteworthy about Lopate's portrayal of the search for meaningful writing instruction: unlike his predecessors, he uses the search as an opportunity to turn himself into a winsome and appealingly bungling character, and, like his predecessors, he discovers that instruction rooted in memoir and students' own experiences yields the most compelling writing. For Tolstoy, Ashton-Warner, and Kohl the search for meaningful writing instruction is an urgent need, a compelling quest, and the reflection on such instruction often takes the form of truthful, conflicted confession. The reader has the sense that the "I" narrating these serious accounts is a wise, idealistic informant, whereas in Lopate's work the "I" becomes a more full-bodied character in their own right, a Chaplin like anti-hero of sorts. In the end, though, what Lopate's anti-hero discovers about writing instruction resembles what Tolstoy's, Ashton-Warner's, and Kohl's heroes/heroines discover-when students are asked to use their own experience as a springboard for their writing they produce compelling work. In teachers' memoirs about writing we enter a space where autobiographical modes of writing govern form and content: teachers write memoirs of teaching students to write memoirs. 
Like his predecessors, Lopate embeds student writing in his own writing. The student writing in Being With Children is mainly collected in a single section of the book, which reviews the history of teaching writing to children and includes seven short chapters on writing lessons Lopate designed. The section is a sort of mini-manual on writing instruction that seeks to inspire students without completely manipulating or coercing them into imitating adult writing styles. In 36 Children and Teacher, the reader gets the impression that Kohl and to some extent Ashton-Warner are embedding student writing in their own writing because they themselves are so moved and impressed by their students' work that they desperately want to publish it, whereas in Being With Children, the reader realizes that Lopate's embeds student writing to make a point about the instruction of writing, to show the results of his own lessons.

The mini-manual on writing instruction is one of five sections of Lopate's book, each of which seems to draw on a different mode of writing as its model. In a 1989 afterward to Being With Children, Lopate comments on this range of modes in Being With Children:

What surprises me most is how many literary modes exist side by side in this one volume: personal and impersonal, narrative, descriptive, didactic, polemical, case history, diary, even a 'novella' (the West Side Story production) smack in the middle. At the time I remember telling myself that since I did not have the courage yet to tackle a novel, I would secretly make Being With Children into a sort of non-fiction novel, with characters, dialogue, and dramatic scenes. In a sense, too, I was already experimenting with that spectrum of essayistic discourse - the jigsaw puzzle, one-man anthology approach I later used in my essay collections Bacherlorhood and Against Joie de Vivredesigned to show off my variety and perhaps make the best of my scatterdness. (399-400)

In terms of structure, Lopate's "one-man anthology" is a very different than Kohl's year in the life of an urban teacher. Teaching memoir, as befits a genre often associated with 
first books and young writers, is a type of writing that lends itself to a range of forms, but the year in the life structure, used by Kohl, and the one-man anthology structure, used by Lopate, as well the diary form, used by Haskins, tend to remain the three primary forms, which later writers use and recombine in various ways.

Lopate describes Being With Children as "a sort of non-fiction novel”(399). In 2009, we have become used to books that are "a sort of non-fiction novel," but at the time Being With Children came out such books were much more unique "more unique" is wrong, but the point is very good, and it may be possible to argue that the roots of this style of writing, which has become so popular, lay,in part, in the teachers' memoirs from the sixties and seventies. Being With Children is more novel-like than Teacher or 36 Children because Lopate works on a bigger scale and is more concerned with relationships throughout an entire school, rather than descriptions of individual students in a single class. The portraits of remarkable students, which appeared in Tolstoy's, Ashton-Warner's, and Kohl's work, turn into multiple portraits of students, teachers, administrators, and their relationship to one another in Lopate's work. There is a precedent, on a smaller scale, for this novel-like approach to the teaching memoir in George Dennison's Lives of Children, an account of the First Street school. Both Dennison and Lopate claim that relationships and the cultivation of relationships are central to teaching and learning, so it is not surprising that their teaching memoirs lean towards a form — the novel—which emphasizes relationships and interconnection among people in a community. 
In 1970, a few years before Philip Lopate published a novel-like memoir about writing instruction, Kenneth Koch published a handbook-like memoir about writing instruction. Like Lopate, Koch was a resident writer in the New York public schools, and like both Lopate and Kohl he was affiliated with Teachers and Writer's Collaborative, a group which brought writers into the public schools and provided a forum for autobiographical accounts of writing instruction. Unlike, Lopate and Kohl, however, Koch uses the memoir form, not to explore the ambivalent consequences of meaningful writing instruction, but to celebrate the outcome of one form of meaningful writing instruction: the teaching of poetry in a manner suited to modernist sensibilities. Gone is the blow by blow account of the struggle to devise meaningful instruction. Instead we hear about how Koch was not initially sure about how to get children to write poetry, but quickly came up with various forms and approaches that would enable young children to write work that sounded more like William Carlos Williams than Tennyson. Also gone is the conflicted reflection on the consequences of meaningful writing instruction. Instead we are invited to celebrate, with Koch, the students' vivid and playful poems. In short, the difficult search for meaningful writing instruction and the reflection on its complex consequences that was at the heart of previous teacher-writers' memoirs has been simplified and sentimentalized in Koch's work.

This is not to say that Wishes, Lies, and Dreams is not an important and worthwhile book. Yet the reasons Wishes, Lies, and Dreams has been republished twice since 1970 probably do not stem from the way it uses memoir to explore the difficulties of becoming a truly good writing teacher, but from the ways it assures teachers, parents, 
and the general public that children can be easily taught to write vivid, life-affirming poems. With Wishes, Lies, and Dreams the possibility of using memoirs of writing instruction to celebrate and promote one's pedagogical philosophy emerges, and future memoirs tend to either take up this fairly straightforward path or to follow the more searching, twisted path of self-scrutiny laid down by Tolstoy, Ashton-Warner, Kohl, and Lopate.

After an initial chapter in which Koch describes how he taught poetry to students at P.S. 61, the rest of the book is divided into short chapters, each of which is a minianthology of a particular type of poem that Koch's students' wrote: class collaborations, wishes, comparisons, noises, dreams, etc. Previously, we saw how the embedding of student writing in adult writing moved from Tolstoy's detailed descriptions of his students' work to Ashton-Warner's, Kohl's, and Lopate's inclusion of students' writing in their own writing. With Koch's book this pattern of lending increasingly more space and significance to children's writing reaches its logical conclusion: children's writing becomes the center of the book and adult writing, in the form of brief commentary, becomes the frame.

In its capacity to give a public voice to those who do not always have a public voice, and to highlight writing by a group whose writing is not often published, this emergence of a child-dominated writing form seems liberating and significant. But it is not a form that simply emerged with Koch's work, rather it is an outgrowth of earlier teacher-writers' tendencies to embed student work in their own work. Behind the many student authored poems on the pages of Wishes, Lies, and Dreams is not only Koch's 
appreciation of his students' artistry, but also Tolstoy's awe at the work of Fedka's and Semka's writing and Kohl's urgent desire to see his students' work published.

\section{After the Seventies: I Am A Pencil, True Notebooks, and Freedom Writers}

During the 80 s and early 90 s there were many teaching memoirs published, but none primarily about writing instruction. Then in the late 90 s and early 2000 s three memoirs about writing instruction were published: I am a Pencil (2005), True Notebooks (2003), and Freedom Writers (1999). Like their predecessors, these books are built around the search for meaningful ways to teach writing in poor communities, and reflections on the ambivalent consequences of such instruction. The ambivalence, however, has been tuned down somewhat, as these memoirs, more so than earlier memoirs, unabashedly present writing instruction as redemptive for both teachers and students.

These books also differ from their predecessors in their greater emphasis on the presentation of student writing. All three books place the students and their written work front and center, moving inward from reflections on students' work and lives to reflections on the teacher-writer's own work and life. Whereas earlier memoirs of writing instruction mostly move outward, focusing first on the teacher-writers' work and life and then turning to the students' work and lives. In sixties and seventies memoirs of writing instruction, the reader understands, at the beginning of the memoir, that the "I " telling the narrative, the teacher-writer persona, suffers from anomie, and that writing 
instruction will gradually provide them, as well as their students, with a more purposeful and authentic way to live.

In post seventies writing memoirs, in contrast, the reader understands, at the beginning of the memoir, that the students' lives are in many ways constrained and difficult, and that writing instruction will gradually provide them, as well as the teacherwriters themselves, with more freedom and agency. The earlier and later memoirs differ not only in their direction of movement--- from other to self, rather than self to other --but also in their representation of writing instruction as a means of gaining freedom and agency, rather than as a means of finding authenticity and purposefulness.

This is not to say that a concern with freedom and agency is not part of earlier memoirs of writing instruction, and that a concern with authenticity and purposefulness are not part of current memoirs of writing instruction, but to recognize that our postmodern skepticism of authenticity may have tipped the emphasis in more recent memoirs of writing instruction from the pursuit of "true" selves to the pursuit of efficacious selves. Writing instruction is still presented in these more recent memoirs as a form of redemption and consolation, but it is, as would be expected, a slightly different form of redemption and consolation than is found in earlier memoirs of writing instruction.

Sam Swope's I Am a Pencil (2005) describes three years spent teaching writing to elementary school students in Queens, most of whom are from immigrant families. It opens with Sam Swope teaching a lesson described by Kenneth Koch in Wishes, Lies, and Dreams, in which young students discuss Thirteen Ways of Looking at a Blackbird and then attempt to write their own poems which look at something in thirteen different 
ways. This opening tribute to Koch reminds the reader that as a memoir of writing instruction, I Am a Pencil, is not just a spontaneous outpouring of one writer's thoughts about his students, but part of a genre with a recognizable history. From Koch, Swope inherits more than just lessons. He inherits the notion that writing lessons, with their uncertain outcome, can be made into compelling narrative, that readers will keep reading to find out how a particular lesson turns out and how a particular child responds.

While Swope's emphasis on the drama of individual writing lessons resembles Koch's emphasis on the logistics of teaching writing, his expansive, novelistic narrative, which follows a group of students across three grade levels and multiple classes, is reminiscent of Philip Lopate, who wrote about not just one class during one year, but a whole school over a number of years. Swope's tone also seems to owe something to Philip Lopate's work. Like Lopate's persona, Swope's persona comes across as at once worldly and hopeful, bemused and seriously engaged in searching for a way to make writing enrich his own and his students' lives. Swope, like Lopate, creates a persona who would be at home on the pages of the New Yorker, one who is nobly idealistic, but also mildly comical and bungling in his attempts to get his students to think and write in new ways.

The raw angst of Ashton-Warner and the political rage of Kohl have been superseded by the urbanity of Lopate in Swope's memoir. In his dust jacket endorsement of I Am a Pencil Lopate, himself, acknowledges how Swope's book fits into the history of teaching memoirs, and takes off where his own and Koch's work left off in the 1970s: 
“Sam Swope's marvelous, moving book revives the teaching memoir where it left off in the 1970 s and takes it to new realms of tenderness, insight and humanity."

Swope imagines writing instruction will enrich his students' lives by freeing their imaginations. Because his students are the children of poor immigrants, seemingly preoccupied with academic achievement, religious constraints, and brute survival, Swope assumes their chances to use their imaginations have been thwarted by their circumstances: "Imagination is something they can have, too, I thought. And in my class, Miguel's would be encouraged to run free. That was something I could give this kid" (40). The search for meaningful writing instruction in I Am a Pencil is first and foremost a search for a way to get students to stop censoring their own imaginations, and write what they truly think and feel. In this attempt to use writing instruction therapeutically to release children's imaginations from the constrictions of school, family, and society, Swope's project resembles Ashton-Warner's and Kohl's projects.

Swope's technique for inspiring students to use their imaginations resembles Tolstoy's method of collaborative composition: Swope jointly produces stories with individual students, in which he writes down what they dictate, in sessions that resemble, at once, classical analysis and the interchange between television script writers in a writing room. These sessions in their vividness and intimacy have some of the voyeuristic quality inherent in both Ashton-Warner's and Tolstoy's work, the feeling that the teacher describing the scene, and hence the reader as well, is watching the private unfolding of children's thoughts and feelings in a manner that is at once a form of revelation and a form of manipulation. 
As in previous memoirs of writing instruction, Swope's search for meaningful writing instruction concludes with reflections on the ambivalent consequences of such instruction. Swope sometimes worries that his attempt to free his students' imaginations causes them to come into conflict with their families. In a conference with a parent he regrets telling a father that his daughter "needs to let her imagination go" (66). He imagines the father going home and chastising his daughter about her inhibited imagination in the same way he might chastise her for not getting the best grade in the class: "Mr. Swope is not happy with you, Fatma. You will not be the top student if you don't let your imagination go" (66). Swope's ambivalence about the conflict between the intellectual culture his writing instruction embodies and his students' more conventional home cultures seems genuine, yet it is also a back-handed way of emphasizing the transformative quality of meaningful writing instruction.

There was this dual purpose in earlier teacher-writers' reflections on the ambivalent consequences of meaningful writing instruction, yet there was also in Tolstoy, Ashton-Warner, and Kohl a lot more honestly regretful awareness of the ways in which writing might provide poor students with forms of freedom which are both liberating and problematic. With the work of Lopate, to a certain degree, and with the work of Koch, to a pronounced degree, agonizing over the consequences of meaningful writing instruction begins to turn into a method of promoting the virtues of meaningful writing instruction. By the time Swope's work is published reflection on the consequences of writing instruction is a necessary, but not necessarily authentic or transparent convention of the genre. 
Much of the pleasure and impact of I Am a Pencil comes from its elegant form, which marks a new development in memoirs of teaching. The sixties memoirs of AshtonWarner and Kohl intentionally appear to largely eschew formal organization in favor of impassioned, associative recollection, although Kohl uses the school year as a container for his recollections. In other words, when the writers and editors devised the form of these books they didn't seem to be thinking of themselves as arranging a teaching memoir per se, because these were among the first teaching memoirs. Lopate and Koch, in turn, advance the formal dimensions of the teaching memoir by creating ways besides the school year to make the work cohere: Koch divides his book into chapters by lesson topics and subjects, and Lopate divides his book into thematic sections with groups of chapters that are variations on particular themes.

Swope combines Koch's and Lopate's method of organization to come up with something new: a three section book grouped around three projects and three grades - the box project in third, the island project in fourth, and the tree project in fifth. Chapters within each project/grade level grouping illuminate the resonant quality of Swope's lessons, as well carrying forward the development of character and plot in observations about how particular children change and stay the same over time. Swope's form allows him to showcase both his teaching, and also create a satisfying plot and characters. This dual task — showcasing teaching and fulfilling the reader's expectations for character and plot development - is one of the central challenges of teaching memoir. In the work of the sixties teacher-writers this dual task seems dependent on the impassioned momentum of a highly committed and unique narrative voice, whereas as with the seventies teacher- 
writers the task of moving plot and character forward while explicating good teaching seems to depend somewhat more on formal choices, and with post seventies teacher's writer's, such as Swope, form seems to be as significant as voice.

I Am a Pencil ends as other post-seventies memoirs of writing instruction do with a movement inward from others to self, the opposite of the outward movement seen in many pre-seventies memoirs of writing instruction from self to others. Swope waits to the end of the book to tell us why he has chosen to teach writing in an urban elementary school, to explain how the processes of teaching writing has been redemptive to himself, as well as his students. When Miguel, a student from a family who are Jehova's Witnesses, worries that he is worthless and God has no purpose for him, Swope suggests that God may not tell him a reason to live, and that he may need to find the reason on his own. He then offers his own brief story of secular salvation:

That's what I did. I was lost in my life three years ago. I felt my life was pointless. But then I decided to do something about it. I found your class and I made a commitment. No, it was more than that. I made a vow. I told myself that for the next three years I'd devote myself to you guys, do whatever I could to help. And it's been an amazing experience. You children changed my life. But $I$ gave my life a purpose, Miguel. $I$ did that. And you can, too. You have to imagine a different life, a good life for yourself, then work to make it come true. Do you understand? (287).

Here Swope offers a secular model of consolation and redemption, grounded in self-reliance and imagination. Swope's speech to Miguel runs the risk of coming across as trite, but it doesn't because it feels earned. It is earned by its position at the end of the book--- its appearance as a surprising revelation, almost an afterthought, rather than an imposing frame. It is also earned through its relation to teaching memoir as a whole, a 
genre which represents writing instruction as a form of redemption. Because previous teacher-writers have represented writing instruction as a form of aesthetic, therapeutic, and political consolation, a way to be both self-reliant and connected, it seems apt to hear it represented, more generally, as a sort of existential antidote to the human dilemma of finding significance and constructing a meaningful life. Swope's words and sensibility are his own, but they are also, in a sense, the words and sensibility of a particular genre, the teaching memoir, speaking a history of imagining meaningful writing instruction as transformative.

What makes this movement towards personal consolation and redemption different in teaching memoirs than in other memoirs is its commitment to always mediating the personal through the public, of linking the transformation of the self and the transformation of others, whether it is in a movement from self to others, as in earlier teaching memoirs, or it is in a movement from others to self, as it is in later teaching memoirs. Speaking of how students borrow and use each others ideas when they share writing, Swope says: "In a sense, all writing is collaborative, more than most of us, even writers, think. Our stories are like islands, connected to people and events and other narratives in ways we cannot always see"(164). More so than memoir proper that can sometimes seem like an island, teaching memoir is always an archipelago in which the persona is committed to mapping his or her own island, as well as the islands around him or her, that seem separate, but are related.

Mark Salzman's True Notebooks, an account of teaching writing at Central Juvenile Hall, is very much an other-focused memoir, which draws its strength from 
keeping its gaze squarely fixed on the students and their writing, more so than the writer's own persona and search for transformation. Ann Fadiman points out that True Notebooks is such a compelling description of a difficult subject because Salzman "has the humility to turn the spotlight on their (the students') writing rather than on his own”. The title of the Salzman's book, True Notebooks, comes from a quote by Loren Eiseley on the importance of a writer keeping a "true notebook," of his or her own thoughts and observations. Salzman makes Eiseley's "true notebook" plural by adding an "s", which implies that we will be reading his students' true notebooks, not just Salzman's true notebook. The "s" makes all the difference, and shows how far teaching memoir, as a genre, has dissolved the solipsistic tendencies of memoir proper in its move from an emphasis on the formation of the self to an emphasis on the formation of selves. Eiseley's work is very much part of the early history of memoir and Salzman's work is very much part of the current history of teaching memoir: the move from Eiseley's "true notebook" to Salzman's "true notebooks" is a synecdoche for the shift from the more introverted world of memoir proper to the more extroverted world of teaching memoir.

The setting of True Notebooks, a juvenile detention center, extends the boundaries of the teaching memoir, as does Salzman's earlier teaching memoir Iron and Silk, an account of teaching English in China. By taking teaching memoir out of the K-12 classroom, and locating it elsewhere Salzman breathes fresh life into the genre, and reminds us of its planetary roots. Like Tolstoy's accounts of teaching Russian peasants and Ashton-Warner's accounts of teaching Maori children, Salzman's accounts of teaching in a juvenile detention center and in China, remind us that the teaching memoirs 
current seemingly fixed location in K-12 urban, American classroom is only one iteration of the genre's wide-ranging, peripatetic history, and that it can and will continue to appear in new and surprising contexts. What seems to remain constant in these iterations ,though, and is as much a part of Tolstoy's and Ashton-Warner's work as Salzman's, is the persona's self-reliant search for meaningful writing instruction and reflection on the ambiguous consequences of this search.

Not surprisingly many of Salzman's students in True Notebooks are interested in writing about freedom, and what it means to be free when one is in prison. The link between writing and freedom that runs though out Salzman's memoir appears again in Erin Gruwell's teaching memoir, Freedom Writers, but the two books couldn't be more different. Where Salzman strives to avoid the clichés of the heroic white teacher, Gruwell uses every cliché in the book, as she tells the story of how her Long Beach high students came to analyze and confront racism through a group of diaries, which they read and wrote: Ann Frank: The Diary of a Young Girl, Zlata's Diary: A Child's Life in Sarajevo, and the class's own diaries. Gruwell claims to being freeing her students from racism and stereotypes through encouraging them to write about their lives, but, ironically, her own writing reifies the very stereotypes she seeks to undercut as she presents the Hollywood version of students in the "hood" and the amazing young white teacher, who helps them find a voice. Part of what makes Gruwell's memoir of teaching so unbearably sentimental and seemingly dishonest is it absence of one of the genre's key ingredients: genuine, unnerving reflection on the truly ambivalent consequences of meaningful writing instruction. Without this kind of reflection on how meaningful writing instruction 
both enables and burdens children there is no real story of struggle on either the students' or the teacher's part.

In a sense, Swope's I Am a Pencil, Salzman's True Notebooks, and Gruwell's The Freedom Writer's Diary mark a fork in the road for memoirs about writing instruction. Swope's and Salzman's work bring memoirs about writing into the literary orbit of creative nonfiction, whereas Gruwell's work points the genre in the direction of less literary, more popular forms of expression. I began this chapter by arguing that many memoirs of writing instruction appear natural, and spontaneous, rooted in personal experience, but are, in fact, highly conventional, rooted in previous memoirs, as much as life itself. Authors of contemporary memoirs about writing instruction are interpreters of their own classes, as well as the literary classes of their predecessors. Behind Swope's and Salzaman's classrooms, and even Gruwell's classroom, is Tolstoy's class at Yasnava Polyana, Ashton-Warner's class in rural New Zealand, Kohl's class in Harlem, and Lopate's and Koch's classes on the Upper West Side. Swope's and Salzman's awareness of this history, stated and implicit, gives their writing a depth that Gruwell's less historically-inflected work lacks. Teachers' memoirs of writing instruction have the potential to change in the future as author's follows Salzman's lead and write about contexts outside the K-12 urban, American classrooms. As they emerge in new contexts and locations, what will, in part, distinguish memoirs about writing instruction that are interesting and ones that are not will be the extent to which their authors demonstrate an understanding of the layers of past classrooms, students, and teachers flowing into their own classes from the pages of previous teacher writers' memoirs on many continents. 


\section{Chapter 4: Memoirs of Relationships}

We might cease thinking of school as a place, and learn to believe that it is basically relationships: between children and adults, adults and adults, children and other children. George Dennison, Lives of Children

Indeed if I could be said to be putting forth any method in this book, it might be summarized in two words, relationship and environmentalism. The first term refers to a desire to ground my teaching in an awareness of the individual characters of my students and colleagues and the nature of the contact between us; the second, to an insistence that good teaching is not a curricular stencil that can be imposed over any situation, but must flow from an analysis of the local situation and an experimental response to it.

Philip Lopate, Being With Children

Our job as adults is to help children build relationships - to people and things in the world and to the act of knowing.

Julie Diamond, Welcome to the Aquarium

Influenced, perhaps, by Erik Erikson's Childhood and Society and other

psychosocial approaches to child development, much sixties and early seventies

educational writing explores the role of relationship in learning: relationships between

children and parents, children and teachers, children and other children. Teaching

memoir, as is already evident in the works of Tolstoy, is a genre of writing that lends

itself particularly well to the exploration of relationship in education, and the

sixties/seventies memoirists seem to repeatedly use the genre for this purpose. Yet

because the memoirists are not writing educational research or sociology, they also seem

to describe the relationships that arise in schools for literary purposes - to create 
compelling stories and characters---as much as for pedagogical purposes. In this chapter, I argue that the memoirists advocate attention to relationship as good pedagogy, at the same time that they use descriptions of relationships for literary purposes to create stories of interconnected characters. In other words, the story told in memoirs of teaching and the pedagogy espoused in memoirs of teaching depends on descriptions of relationships. Behind Lopate's interest in relationship as educational "method," his desire to ground his teaching in the "nature of the contact between" students and colleagues as "individual characters" it is not hard to hear the writer's desire to base his writing on vivid, idiosyncratic characters with interesting relationships. In depicting, what George Dennison refers to as "simply the lives of those who were involved... the jumble of persons and real events" that "constitute a school" the memoirists show us their relationship-based theory of education, and also create character-driven, novel-like nonfiction (5).

A comment by Herbert Kohl on Philip Lopates's Being With Children shows the dual role of relationships - pedagogical and literary - in teaching memoirs:

Lopate observes the life of each child he works with and how much he is on their side and, in spirit, one of them. This sensibility, together with the ironic and humorous way in which Lopate makes all of the children and adults in the book come alive, turns the work into literature, with characters that stay with you long after you close the book. (Lopate, 2008)

Here, observing the life of each child is good teaching that in turn becomes good writing: the attention to character and relationship for pedagogical purposes becomes the foundation of the attention to character and relationship for literary purposes, combining the author's role as teacher and writer. This double role of relationship in teaching 
memoir — pedagogical and literary_ gives the reader a more visceral and emotional recognition of the significance of relationship in teaching and learning than conventional educational research, which can often tell us why strong relationships foster learning, but often cannot make us feel the emotional impact and individual significance of strong relationships on particular children in particular schools. This is one example, of the way memoir, with its novelistic language, has the capacity to speak a different language than educational research, a narrative language that has largely dropped out of educational reform. This is not, of course, to say that memoir should replace educational research, but to say that there are areas of education, such as the role of relationships in schools, to which memoir offers more direct access than educational research.

School as "basically relationships," such as Denison describes, and teaching grounded in the "nature of contact" between students and colleagues, such as Lopate describes, does not, of course, happen in a vacuum. There must be some context for these relationships to exist in schools as actual events, and on the page as literary events. In other words, people and characters form relationships because they are trying to work on something together. What allows relationships to form in teaching memoirs is self-reliant teaching, teaching that ignores conventional educational practices, and focuses more on analyzing and responding to a local situation in an experimental manner, as Lopate suggests. The acts of self-reliant teaching, the experimental responses that build relationships in memoir, reject conventional curricular activities in which students' remain separate and passive, in favor of teacher-devised activities where students are connected and active. 
In teaching memoirs the context for relationships is more often than not making stuff together - art, music, plays, videos, writing, conversations and debates — or going places together - around the countryside or the city to see and learn outside the classroom. In these different contexts - making stuff and going places - friendships arise between students and other students, and teachers and students, as well as other forms of relationships that are not really friendships - apprenticeships, rivalries, parent-like mentoring, etc. This chapter considers how three contexts--- making stuff, going places, and student portraits --- enable teacher-writers to champion a relationship-based pedagogy and create compelling characters. Such a relationship-based pedagogy and keen presentation of individual characters attests to the memoirists' preoccupation with self-reliant teaching, and its capacity to foster the idiosyncratic connections between particular children and particular teachers. Such self-reliant teaching insists that the teachers' knowledge of particular students, gathered from observation and interaction , not preset guidelines or prescriptive directives governs the content and direction of lessons, just as an author's knowledge of particular characters governs the content and direction of their narrative. Here self-reliant teaching is not so much an act of selfexpression, in which a teacher seeks to show students what they themselves value, as an act of connection, in which the teacher seeks to design their own curriculum to foster the development of relationships between people.

\section{Tolstoy and the Representation of Relationship}


Herbert Kohl's remarks on Being With Children explain how relationship plays both a pedagogical and a literary role in Lopate's memoir. Like so much else in teachers' memoirs this tendency to highlight relationships for both pedagogical and literary purposes can be traced back to Tolstoy's essays on Yasnaya Polyana, which had a direct influence on Ashton-Warner and Dennison, and of which the other memoirists were probably aware.

Both Dennison and Ashton-Warner use references to Tolstoy's school at Yasnaya Polyana to justify their pedagogies of relationship. Dennison has an entire chapter devoted to Tolstoy's educational writing and ends Lives of Children with a long quote from Aylmer Maude's The Life of Tolstoy, in which one of Tolstoy's former students, Leo Nikolaievich, fondly recalls the school at Yasnaya Polyana, and the students' relationship to Tolstoy. The quote begins with the description of a joyful snowball fight between Tolstoy and his pupils, and ends with an idealistic description of Tolstoy's teaching and tale telling, in which there is an equal exchange of stories between teacher and pupils: "We told him terrible things — about wizards and wood demons...He told us tales, terrible or funny, sang songs, suiting the words to us" (282). The students are described as growing "close to Leo Nikolaievich as a cobbler's thread is to wax" (282).

Dennison uses this extended account of Tolstoy's relationship with his students, as an example of the importance of community, which in good American fashion Dennison views as an ideal space where both relationships and libertarian values can flourish, where local authority trumps centralized authority and individual initiative trumps bureaucratic mandate. What is fascinating to me about this idealization of 
community in education is not the question of whether it improves education-I believe it does-- but the fact that it makes for a compelling literature about schools. A pedagogy of relationship grounded in community is a pedagogy with novelistic potential, with a world of quirky characters and human interactions worth reading about, whereas a more centralized, bureaucratic pedagogy has no story to tell. What I am suggesting is that in describing educational reforms based on the centrality of relationship, teacher-writers such as Tolstoy and Dennison, also, in effect, create a literature of school reform, where before there had primarily been a philosophy, history and sociology of school reform.

Ashton-Warner, like Dennison, attributes her interest in the role of relationship in education to the works Tolstoy. But as is typical of Ashton-Warner, she uses language that casts the question of teacher student-relationships in more erotic, more intimate terms than other teacher-writers. According to Ashton-Warner "Tolstoy wrote he had a passionate affection for his school. Under his guidance other young people who helped him in his work developed a similar "passionate affection" (29). In her own work, Ashton-Warner uses the language of espousal to describe her own "passionate affection" for her students, as she speaks at length about how when she teaches people "I marry them" (209) and how "there is quietly occurring in my infant room a grand espousal. To bring them to do what I want them to do they come near me, I draw them near me, in body and in spirit" (210).

As is often the case with Ashton-Warner it is difficult to know what to make of this frank use of erotic language to describe teacher-student relationships. It is too easy to dismiss her erotic language as simply in bad taste. Rather, it seems designed to mildly shock the 
reader into realizing the emotional intimacy with which some compelling teachers do their job, and also to again make literary claims for teaching: to borrow, like some religious poets, the language of eros to describe agape, to use one type of love as a metaphor for another type of love. In this use of erotic love to depict pedagogical love, Ashton-Warner is not simply being mildly shocking; she is situating herself, and thereby also her work, in a long line of literary writers who have used the language of erotic love to represent other forms of love. What then is new is not the use of one kind of love to represent another, but the context in which it is done - a teacher's memoir, not a lyric poem. A new genre- memoirs of teaching--emerges as writers apply the conventions of other genres - in this case lyric poetry---to circumstances and situations they had not previously been applied to.

\section{Making Things}

Children relate to one another by means of enterprise - play, games, projects. Which is to say that they are never bogged down in what are called "interpersonal relations." For interpersonal relations are precisely those words, deflected acts, and emotions which occur when shared activity ceases or becomes impossible: our long conversations, our opinions, our attitudes. We "relate" to one another, that is, we jockey around in the sticky ambience of personality traits, neuroses, insecurities, trivial aggressions, practiced egotism, regret, bitterness, self-love, complacency, arrogance, vengefulness, etc. Children do not and cannot. They penetrate this ambience quickly - it is always rudimentary anyway - and they get on with shared activity that is exciting. George Dennison, Lives of Children

\section{In Lives of Children George Dennison explains how projects and shared activity}

enable children to develop relationships with each other, but it is also worth noting that the description of projects and shared activity in memoirs also enable teacher writers to 
depict characters' relationships, and thereby provide a means of creating a compelling narrative, as well as a compelling class. Writers, particularly Wordsworth and the Romantic poets, often describe how children make models and plays to imitate, in miniature, aspects of adult life. Analogies have often been drawn between the creative capacity of the writer or artist and the creative capacity of the child.

In memoirs of teaching these analogies are drawn again, but this time they do not ,as in the works of the Romantics, involve an adult contemplating the creative acts of their own childhood, or of a singular, representative child. Instead, memoirists represent groups of children making things together, and thereby open up the possibility of using the representation of children's projects, "shared activity that is exciting," not just to contemplate the creative roots of art and literature, but also for pedagogical and literary purposes: as a means of exploring the meaning of relationships in schools, and as a means of turning students and teachers into characters with relationships worth reading about. In the British and New Zealand memoirs of teaching from the early sixties the accounts of shared projects are meant primarily to demonstrate the value of a pedagogy focused on imagination and relationship, yet there are contained in these accounts vivid, miniature sketches of the characters of individual children, as well as small, compelling dramas, which interest the reader in the world of the memoir. In later memoirs of teaching from the mid-sixties and beyond, particularly American ones, the latent literary qualities - the development of character through the portrayal of relationship — which was inherent in the accounts of shared projects in the earlier British and New Zealand memoirs, become the point of describing shared projects, as much as the concern with 
testifying to the pedagogical value of making things together. Each successive group of memoirists makes their memoirs less like a manual or diary and more like a novel, as they realize the potential for developing character inherent in accounts of projects.

Three of the earliest memoirs of teaching from the sixties---Sybil Marshall's An Experiment in Education (1963), an account of eighteen years work at Kingston County Primary School in Cambridgeshire, Elwyn S. Richardson's In the Early World (1964), an account of a number of years spent teaching at a primary school in Oruaiti, New Zealand, and Sylvia Ashton-Warner's Teacher (1963)---focus primarily on descriptions of a teacher and students making art together---painting, print making, music, writing, and clay crafts. In all three books, the reader is meant to recognize the pedagogical value of these creative activities, yet because of the vividness and precision of the writing one cannot help being drawn in to thinking about the relationships that are the inevitable offshoots of such

engaged work. In other words, as readers of these memoirs we are positioned to read for information - as though we were reading an essay or a book on what practices constitute good teaching---but we also find ourselves somewhat surprisingly and surreptitiously reading to understand the unfolding of relationships, the revelations of plot and character, found in novels and short stories. This double positioning of the reader testifies to the hybrid nature of an emerging genre, a genre in which the reader's and writer's roles are new, tentative, borrowed, and combined from other genres and sources. Some of the excitement of making things, which is the topic of these art-centered books, comes across 
in the reading of them, as the reader senses the newness and freshness of what the writers are trying to do in their combination novel-like, essay-like, and manual-like discourse.

The description of teachers and children making art together continues in the later memoirs of teaching published in the United States in the mid-sixties and early seventies. However, whereas the earlier British and New Zealand memoirs focused on painting, crafts, and music, the American memoirs focus more on video production and drama, considerably enlarging the possibility for representing a variety of relationships. The relatively controlled manual-like focus on how to make things with children and the explicit emphasis on the pedagogical value of such joint-creative production found in the memoirs from England and New Zealand is gone, replaced in the memoirs from America with entertaining novel-like accounts of what it is like for teachers and children to work together on big, messy, open-ended projects, that risk the possibility of failing at worst, and challenging the whole fabric of what it means to be a teacher and student at best.

In How To Survive In Your Native Land James Herndon describes making a movie -Return of/ Son of Hawk-with students. In a streaming, mildly ironic style that one would expect to find in a beat novel, Herndon tells the reader that he and another teacher made the movie with the students because they wanted to, not to achieve various educational goals:

Had we wanted to See What The Kids Would Do With Film, we'd have no doubt come up with something more constructive---a film about Attitudes and Relationships or The Question of Authority and or/Democracy In the Classroom... as it was, we really wanted 
to make a Tarzan film but couldn't quite see how it could be done and settled for the Hawk. (44)

The intentional irony of Herndon's claim ---that he made the film not because he wanted to teach the students something about relationships or the question of authority and democracy, but because he was inspired---is that Herndon's inspiration indirectly leads the students to learn a lot about relationships and authority and democracy.

When Herndon and the teacher he is working with initially introduce the idea for the film - a movie about "a mad kid who murders everyone in school" - they are running the show, but the students quickly become more interested and involved than them, and end up concocting a mad cap murder mystery with a completely different plot than the teachers originally envisioned: "Frank and I had been edged out as director and cameraman and organizer without any fuss" (48). What follows is a description of the relationships between the students as they democratically make the film themselves, without relying on the authority of teachers. The teachers' inspiration leads to the students' inspiration, and inspiration--a highly literary approach to the conception and initiation of a project---not educational theories becomes the means of producing a pedagogy grounded in relationship and democracy.

Like Tolstoy describing how his own interest in proverbs inspired his students to write, Herndon in his description of the production of The Hawk articulates an essentially romantic, literary pedagogy, grounded in the belief that individual inspiration can facilitate growth, change, and the making of meaning. Given recent historical eventsschool shootings and highly standardized curriculum — it is nearly impossible to imagine 
an event comparable to the making of The Hawk in a public school, and we should not, of course, value Herndon's account of the film as some form of lesson plan to be enacted next week, but as a memory of a moment when inspiration lead to the opening up of a space for "genuine" relationships and democracy in the classroom. If as educators we wish to take Herndon's work to heart we should be thinking not how do we make a comparable movie about school violence with students, but how do we find ways to inspire students by demonstrating what inspires us, and then giving them ownership of what they have learned from us.

James Herndon, as is characteristic of his writing in general, uses an "outsider" persona to describe the production of the Hawk, an "I' who casually seeks both irony and transcendence in ordinary school-life, but who is not particularly interested in the use of the telling detail to convey the development or essence of any one child's character. Herndon, as is evident in other sections of How to Survive in Your Native Land, is very much capable of using detail in this way, but his generic reference point in depicting the production of The Hawk seems to be more essayistic than novelistic. In contrast, Philip Lopate, in his depiction of the production of West Side Story in Being With Children is very much concerned with the use of the telling detail to convey the development or essence of particular children's characters. His generic reference point seems to be novelistic in this section of Being With Children, and he has referred to the West Side Story section of Being With Children as a novella of sorts (399). Two descriptions of drama at school for pedagogical and literary purposes, Herndon's and Lopate's work are similar in intent, yet different in style and form, different in voice. 
In The Big Show, a chapter of Being With Children in which Lopate describes how the children at PS 90 put on West Side Story, Britt, Xiorma, Dolores, Willie, Luis, and a host of other children are vividly conveyed in all their quiddity and quirkiness. Recognizing Lopate's compelling use of school drama to portray children's characters, Herbert Kohl, in his introduction to the recent reissue of Being With Children singles out the The Big Show as one of "the most wonderful dramatic and truthful writings about what day-to-day life is like when you stretch out with smart but wild kids" (xvi). Not surprisingly at the beginning of The Big Show, Lopate quotes two lines of a Jet's song on the inevitability of relationships: "You're never alone, You're never disconnected". (143). Yet despite this chapter's in depth exploration of the pedagogical and literary value of relationships, the chapter ends in a rebuttal of the opening quote, in a recognition of each adult's essential solitude.

In a Wordsworthian moment of contemplation, rendered in an almost film-like style, at the close of The Big Show, Lopate risks sentimentality and vulnerability to say something compelling about the function of relationship in adults' and children's lives. In this very staged scene, the teachers leave Lopate to conduct the cast party for West Side story on his own:

Denise stirred herself. "Hey, it's late. We've got to pick up our classes from the yard." They started making their way out.

"You mean you are not going to stay for the party?" I said, suddenly very lonely.

"Nah, we've got to stay with the other kids. We'll send the kids from the cast down to you in a few minutes. Have a good time," said Denise. They seemed not to sorry to leave.

"We'll come down for a few minutes if you have a chance," I said to all of them. "We will...Have fun." 
They were gone. I was alone in the enormous gymnasium behind a table of party candy, feeling rather foolish. The sunlight was streaming through the window gratings and playing tricks with the scuffed-dull wood panel floor. I noticed motes of dust floating through the light, light that fell in arcs just beyond the wall benches and then diffused over the great space.

Presently the girls started coming in. Yolanda was very excited.

"We're going to teach the boys the meringue!"

She set up the record player with a stack of $45 \mathrm{~s}$. Kim, a timid blond girl who was not so sure she knew the meringue and had joined the stagehand crew at the last minute, went to work seriously on the chocolate malted balls.

"I like the kind that get your hands all red."

The last show of West Side Story has been put on, and Lopate finds himself alone at the end of the play, like many a director in other accounts of theatre, but, unlike these other directors, he is alone in time as well as space, alone between the adult world of teachers and the childish world of students. The motes of dust are a bit corny, but in an almost film-like way they seem intended to signify the speaker's literary intentions, his deft positioning of himself as a Wordsworth-like lyric "I," suffused with a sense of both the distance and proximity of childhood in adults' lives. Given this adult isolation---the romantic, fallen status, of the speaker-- the depiction of children's relationships in the Big Show becomes a vicarious pleasure of sorts for the adult author and reader, a secular form of healing and redemption disguised as a comic account of a bunch of kids putting on a play.

Like Philip Lopate, but thirty-five years later, Nilaja Sun is a teaching-artist in the New York City public schools, who uses her experience to produce a memoir of her work. Sun's memoir takes the form of a one woman play, No Child, about a group of New York city public school students producing a play with their teacher, who is the author of the play the audience is watching, and also the only actor, playing the parts of 
the teacher as well as all the students. One can find many traces of the history of memoirs about teaching in No Child, which I look at in the chapter on Memoirs of Educational Injustice. In regards to this chapter, what is significant about No Child is the way it furthers Lopate's use of drama to build relationships for both pedagogical and literary purposes, relationships which help students form a meaningful community and relationships which help readers and audiences care enough about characters to invest their thoughts and feelings in the unfolding of one teacher's memoir.

\section{Going Outside}

Outside the school, in the open air, new relations between the students and teachers establish themselves, despite all the liberties granted the students in school. The greater liberty, simplicity, and trust between the students and teachers outside the school are our ideal for what we should strive for in the school.

Leo Tolstoy, The School at Yasnaya Polyana

All sorts of things can happen in a walk, not the least being experience itself. Sylvia Ashton-Warner, Teacher

Students and teachers are always going outside in sixties and seventies memoirs of teaching. Field trips seem to be the norm, rather than the exception. The descriptions of these trips outside, like the descriptions of students making things together, have both a pedagogical and a literary purpose: they become a means of testifying to the educational value of the relationships possible in the world beyond the classroom, and also a means of developing characters with interesting relationships to one another. These excursions in sixties and seventies teaching memoirs seem to grow out of a 
fascination with experience-based education, as well as the related yet slightly different traditions of the romantic stroll and the "roving observer" or flaneur.

It is worth looking in detail at one of the passages where Tolstoy describes a class excursion because so much of what he does seems to establish the precedent for subsequent accounts of class excursions. In the The School at Yasnaya Polyana Tolstoy describes an evening walk through the forest, which he marks as a literary event from the beginning by telling the reader that the walk occurred after the class had read Gogol's "Elf-king," and that their imaginations were much affected by the last scenes. Tolstoy begins by describing the characters of Fedka and Semka, two of the students he is walking home, but as the group draws closer to the forest, with its wolves and other mysteries, Tolstoy changes his persona from that of adult teacher and distanced, thirdperson narrator to that of a member of the group, an "I" who is one of the boys contemplating the mystery of the woods at night. Emerging from the forest, Tolstoy and the students identities shift yet again from boys together to that of parent and child, as Fedka, growing afraid of the dark, places his hand in Tolstoy's hand.

The conversation between the teacher and students that transpires during this outing is a small novel in of itself and covers everything from a tale told by Tolstoy about robbers in the Caucasus, to anthropological-like observations on the behavior of peasant children, to a child's wise questions about why we sing, write, and draw. All of this wide ranging conversation about philosophy and life remains, as is the want of literature, solidly rooted in a physical world, whose representation shifts from the slightly ominous landscape at the border of the village to the houses of each child, as they leave the group 
and return to their respective homes. In a short, dark walk home the teacher, the students, and the reader have covered a lot of ground and changed in the ways that characters and readers of longer narratives - short stories and novels - often change. The passage is literary in the senses that Derek Attridge has pointed to in The Singularity of Literatureit is a moment of alterity amongst passages of more work-day pedagogical prose about the running of a school.

I describe this passage in detail because it seems to me that in this passage Tolstoy has hit upon a new form of literary writing that combines the conventions of the walk in Romantic literature with the conventions of the pedagogical report or account of a particular type of schooling. The pedagogical or instrumental reasons given for presenting the passage - "outside the school, in the open air, new relations between the students and teachers establish themselves"---are fairly quickly superceded by the literary quality of the writing-- its inventiveness and responsiveness to "otherness". This eclipsing of pedagogical/instrumental purposes by what I see as essentially literary purposes will continue to occur again and again in memoirs of teaching, as memoirists describe excursions outside the classroom which are, perhaps, initially meant to articulate the educational benefits of class outings, but end up as tiny, resonant mini-novels, or snap-shot like short stories with a vivid life of their own.

Speaking of Tolstoy's dual role as teacher and writer, Troyat in his biography, says "however hard Tolstoy tried to keep him down, the man of letters kept pushing through the pedagogue" (216). This could equally well be said of the sixties and seventies memoirists as they describe their classes' excursions in the country and city. What may 
have started out as a serendipitous, more or less unintentional eclipsing of pedagogical purposes by literary purposes in Tolstoy's description of a class outing becomes a fully intentional shift in the work of later teacher-writers who, with the benefit of hindsight and the availability of previous memoirs, seem to recognize from the start the literary potential inherent in the portrayal of the class outing. As a liminal space between school and home, a space open to surprise and otherness, the class outing lends itself to the development of a literary sensibility in teacher-writers, their students, and their readers. Albeit, a literary sensibility whose piquancy is dependent on the contrasting representation of the more ordered, predictable, role-bound life inside of school buildings, where generally teachers are teachers and students are students, and there are no blurring of the lines between the roles of teacher, student, parent, and friend, which often seem to occur in the open, undefined space of the field trip.

I have already described how as teaching memoirs move from New Zealand and Britain to the United State, the emphasis on making things together shifts from an emphasis on craft, art, and music to an emphasis on drama and video, or from what could be seen as more or less traditional art forms, readily pursued in the country or the city, to what are more often than not more urban, collaborative performance-oriented art forms. Similarly, as teaching memoirs move from New Zealand and Britain to the United States, the class outing in the countryside, with roots in the Romantic country walk, becomes the class outing in the city, with roots in the flaneur's stroll.

In Teacher Ashton-Warner takes the students outside to teach them the proportions inherent in the "golden section," and the photos work in collaboration with 
the text to document a series of class excursions, which read like a collection of linked, free-verse poems. Dennison concludes The Lives of Children with a beautifully rendered account of a whole school excursion to Alpine Park, which could be read as an updated versions of Tolstoy's outings with his students or as a parody of sixties schooling, as everyone piles into the microbus: "We had piled the whole school into the microbus, kids holding kids on their laps, kids and teachers sitting on the floor. A cop looked in the window just as we left the school, and his jaw dropped. 'Christ,' he muttered, 'drive, careful, buddy “(241). The narrative goes on to describe a picnic in Alpine park where students and teachers roles and relations shift and expand in ways comparable to the night-time excursion described in Tolstoy. Concluding, like Tolstoy, with the delivery of each child to their respective home, Dennison moves through the city in a microbus, rather than through a village on foot.

In 36 Children Kohl's students walk with him from Harlem to Park Avenue and Columbia University, all the while noticing the differences between the streets on which they live and the streets they are passing through. Lopate's students, like miniature Baudelaire's, walk through Manhattan jotting down "word photographs" and stopping in at the local McDonald's to talk with whoever is hanging around. Thirty years later, Sam Swope's class in I Am a Pencil travels from Queens to Central Park to look at the winter trees they plan to write about, and as they talk and think about the landscape they pass through it is hard not to recall Tolstoy walking through the dark forest with his students, in another winter on another continent. 
What all these instances of teachers and students going outside together have in common is the way they expand the traditions of the rural Romantic walk and the urban flaneur, both of which conventionally turn on the portrayal of a single, isolated self encountering the landscape or the crowd on their own, but here involve a class of selves. It would seem to be a contradiction in terms to have a group of poetic ramblers or a crowd of flaneur, kind of like a flock of cats, but that is what the class outing in memoirs of teaching provides, in a grounded, pragmatic, somewhat funny and sentimental sense that comes from taking a highly contemplative literary tradition - the excursion---and applying it to the unfolding relations between teachers and students, as they move through the world together. The teacher-writer, like the poetic rambler or the flaneur on their walks, remains the central consciousness on the class outing, the eyes through which we see the world, but consciousness is also simultaneously diffused as the teacher-writer imagines what their students are thinking and feeling as they encounter new people and places.

Levinas' injunction - that we only know the self through striving to know the other-seems more to the point here than in the traditional portrayal of the flaneur or the poetic rambler, where the alienation of the individual self often seems to preclude the fusion with the crowd or the landscapes which the speaker seeks. Here, in class outings, as in some of Whitman's representations of walking in the city, the alienation of the individual self dissolves, momentarily, in the relationship with other selves: students and teachers together, walking, thinking, and looking. 


\section{Portraits of Individual Students}

We have looked at how teacher-writers use the portrayal of students making things together and the portrayal of students going places together for both pedagogical and literary purposes: to show the social, psychological, and educational benefits of relationships, and to use the representation of relationships to create compelling characters, who interest readers. Even more so than making things and going places, the portraits of individual students in teachers' memoirs are a means of testifying to the value of teacher/student relationships and also a means of developing characters. Portraits of individual students could, in fact, be seen as a generic signature of memoirs about teaching, in so far as they appear in almost all memoirs of teaching, good and bad, current and historical. Numerous recent memoirs of teaching, such as McCourt's Teacher Man, Codell's Educating Esme, Halprin's Losing My Facilities and Michie's Holler If You Me are built around portraits of individual students, but I am not as concerned about the current prevalence of the student portrait in teachers' memoirs as I am interested in the form's evolution, from its appearance in the work of Tolstoy, who may have found it in Rouseau's Emile or Berthold Auerbach's, Ein Neueus Leiben, through the work of the sixties and seventies teacher-writers, to the work of contemporary teacher-writers.

Portraits of individual students often take a variety of forms, and may contain opinionated or fairly objective descriptions of a student's behavior, samples of their conversations in dialogue form, interpretations of their motivations and background, and explanations of their relationship to the teacher and other students. In other words, the portraits almost always contain some form of mimetic narrative, as well as some form of 
more analytic, essay-like discourse, but they do not, surprisingly, read like ethnography, and the reason for this seems to be their deep connection to the four central themes of teaching memoir - inspiration, failure, poverty, and self-reliance.

Again and again the portraits of individual students in teaching memoirs become a way to grapple with these very compelling, and essentially literary themes. It is almost possible to imagine a typology of student portraiture in memoirs of teaching arranged thematically. For each of the four themes I view as central to memoirs of teachinginspiration, failure, poverty, and self-reliance - there are numerous portraits of individual students that explore the given theme. There are portraits of students whose highly literate sources of inspiration echo the teacher-writers' own sources of inspiration, and portraits of students who teacher-writers' fail to inspire with their own sources of inspiration. Similarly, there are portraits of students whose actions, behavior, and attitude to learning testify to a particular teacher-writer's failure to engage them or teach them properly. There are portraits of students who seem, in remarkable ways, to have overcome what others' perceive as the limitations imposed by poverty and portraits of students whose potential has seemingly been limited by poverty. There are portraits of students who have not found ways to be self-reliant, and portraits of students, who with the help of teacher-writers, have glimpsed what it means self-reliant, or conversely have taught the teacher-writer or other students the value of individual freedom. Finally, there are portraits of students that engage all four themes - inspiration, failure, poverty, and self-reliance-simultaneously. 
In all these student portraits, as in most creative nonfiction concerned with others, assumptions are continually made, but in the best student portraits assumptions are made and undone and remade in a continual processes, an ongoing attempt to use the small, personal relationship between one adult and one child to somehow loosen the knot of class, race, and gender assumptions that holds us all in its sway. In these student portraits, as in the border crossing memoirs we looked at earlier, there is always the problem of reifying the very injustices one seeks to dissolve, of producing difference by naming difference, yet the best portraits of students are aware of this paradox and acknowledge it in their writing in ways that make their words more personal, more troubling, and I would argue more literate than works that don't see how student portraits both expand and constrict our views of children from backgrounds that may differ from our own.

It is worth looking briefly at how successive teacher-writers take up the convention of the student portrait and use it in ways that are both different from and the same as their predecessors. In The School at Yasnaya Polyana Tolstoy presents a portrait of Fedka, a boy he also described in Are the Peasant Children to Learn to Write from Us, or Are We to Learn from the Peasant Children. As is often typical of student portraits in memoirs, a particular incident--- an evening walk---provides the context for the portrait of Fedka, but Tolstoy does not limit his description of Fedka to the evening walk, as he brings other seemingly unrelated, but actually highly relevant, knowledge to bare on his portrait of Fedka: what a daring swimmer he is. As the portrait progresses, it weaves together Tolstoy's past knowledge and present knowledge of Fedka, his description of 
Fedka's physical appearance and behavior, as well as his assumptions about Fedka's character and personality:

Fedka, a small boy of ten with a tender, impressionable, poetic, and bold nature, was the most persistent in his demands. Danger seems to be his main recipe for enjoyment. In the summer it always made me shudder to see him swim out to the very middle of the pond, which is some 350 feet wide, with two other boys, and now and then disappear in the hot reflections of the summer sun. Fedka would then swim over the deepest part, turning on his back and sending up a spout of water, calling out in a thin voice to his companions on the shore so that they could see what a fine fellow he is.

Fedka knew that there were wolves in the forest, and therefore he wanted to go to the preserve. The others chimed in, and so the four of us headed off to the forest... (91-92)

The swift, initial summing up of personality and character, accompanied by a brief physical description and a vivid anecdote are Tolstoy's legacy to later teacher-writers as they use a similar format in their portraits of individual students, which, like Tolstoy's portrait of Fedka, become compressed, piquant, miniature character studies, with seemingly broader resonance than their brevity initially suggests. After this initial portrait of Fedka, his work---particularly his writing, his gestures, and his responses to Tolstoy's teaching--keep cropping up at unexpected moments throughout the account of Yasnaya Polyana. Thus when Tolstoy describes his students reactions to a history lesson he represents Fedka's response more vividly and specifically than the rest of the class:

He stopped in his tracks! Fedka corrected me. Fedka, red in the face, was sitting opposite me, bending his thin, dirty fingers in excitement (This is his habit.) The moment he said that, the whole room groaned in ecstasy of pride. A little fellow in the back row was being crushed, but nobody noticed. (147)

Fedka and his relationship to Tolstoy — starting with the initial portrait of him on the evening walk — seems almost, but not quite like a theme running throughout the Yasnaya 
Polyana essay. The intermittent accounts of Fedka, however, seem too off the cuff, too incidental to be a theme or motif intentionally inserted to hold the essay together. What is seemingly a form of improvisatory discovery in Tolstoy - the portrait of an individual student and subsequent anecdotes about the same student—-becomes in the memoirs of later teacher-writers an intentional means of building character and creating narrative coherence.

Taking off where Tolstoy left off the sixties and seventies teacher-writers create vivid portraits of individual students, which like the portrait of Fedka, have the quality of both a snap shot and an echo, a snap shot in so far as they capture some momentary characteristic gesture of a particular child at a particular instance, and an echo in so far as they seem to set off a reverberation within the text, which guarantees that the teacherwriter will return, intentionally or unintentionally, to thinking and talking about the child in the portrait. In Sylvia Ashton-Warner, we see this snap shot and echo sequence, in the portrait of Matawhero, a Maori boy who Ashton-Warner regrets becoming enraged at for hitting a white boy. The portrait of Matawhero is also a portrait of Ashton-Warner's own failure as a teacher, and each time she returns to a description of her relationship to Matawhero she also returns to a consideration of how she has failed him as a teacher. Photos of a little boy of about six or seven accompany the initial verbal portrait of Matawhero and also subsequent descriptions of him, but we are not told that the photos are necessarily of him, so we are left to look and surmise, which creates a much more vivid, curious form of looking than if we knew for sure the photo represented Matawhero. In fact, this uncertain form of looking brought on by the unlabeled photos loosens the 
whole notion of an accurate student portrait, and casts a certain redemptive hesitancy on the whole questionable processes of trying to elucidate a child's character in a verbal or visual description.

The photos of the boy who may or may not be Matawhero and their uncertain relationship to Ashton-Warner's verbal portrait of Matawhero invites a punctum-like reading, a reading in which we are simultaneously wounded, interrupted, and fascinated by the possible images of a child mistakenly chastised by a teacher, who is in danger of the racism we ourselves are in danger of in our very interest in Matawhero. I do not know whether Robert Gottleib,sp the original editor of Teacher, or Ashton-Warner herself came up with the idea of using photos and verbal portraits in this elusive way which complicates and problematizes the voyeurism inherent in the narration of colonial education, but for me the relation between the photos and the text in Teacher, are often as fraught, suggestive, and meaningful as the relation between photos and text in works better known for a juxtaposition of photography and writing, such as W.G. Sebald's stories and essays.

Closest, perhaps, to Tolstoy's use of the student portrait is Dennison's use of the student portrait. Tolstoy's portrait of Fedka is, in fact, a double portrait of two children- -Fedka and Semka, with Semka mentioned much less often than Fedka. Similarly, in The Lives of Children, Dennison produces a double portrait of Jose and his sister Elena, but speaks far more often of Jose - a child who struggles mightily to read — than he does of Elena. As in the case, of Fedka and Semka, who both reappear periodically throughout Yasnaya Polyana after their initial portraits, Jose and Elena appear repeatedly throughout 
the Lives of Children. Previously, I said that Fedka's relationship to Tolstoy almost seems to be a theme in Yasnaya Polyana; in Lives of Children, Jose's relationship to George Dennison seems very much to be a theme. One of the last images in Lives of Children is of Dennison driving various children home after a picnic, and dropping Jose off last, just as Tolstoy had brought Fedka home last, after a night time walk through the woods. Dennison's trip to Jose's apartment building echoes Tolstoy's trip to Fedka's house, but what seemed to be somewhat spontaneous in the older writer's work-an account of a surprising teacher student friendship- becomes in the later writer's work an intentional means of creating characters and championing the value of relationship in education,

Kohl and Kozol, and Faden also take the portrait of an individual student in new, more polemical directions. Kohl in 36 Children structures his memoir around the portraits of a small group of students, but he is primarily interested in Robert, a gifted writer and artist whose opportunities often seem thwarted by poverty, and Alvin, a child who "wrote only through inspiration, which came too infrequently to prevent constant restlessness and self-doubt" (70). Kohl extends the time frame of student portraits by telling us what happens later to the students he takes an interest in-Robert, Alvin, and others. Because many of the students he follows struggle to have the same agency they had developed in his class these extended portraits become an indictment of the limited opportunities facing children living in poverty.

Kozol in Death at an Early Age also uses his portraits of individual students for polemical ends when he adds a Dickensian sensibility to portraits, as in his opening description of Stephen, a child who is repeatedly beaten in school. Faden in The Naked 
Children uses initial portraits of four children who are friends---Cleo, Wentworth, Snapper, Rubbergut-- and subsequent accounts of his outings with all four friends to describe the limited opportunities for the development of academic literacy in the segregated Washington DC schools of the late sixties and early seventies.

As one might expect, Lopate and Herndon, in their portraits of individual students develop the humorous, literary sensibility that was latent but not fully articulated in Tolstoy's portraits of individual students. Lopate has numerous masterful portraits of individual students in Being With Children, but one particular portrait-Francis, the Adult in the Child - stands out for its subtle, surprising writing and its revelation of Lopate's own character. Impressed by the writing of Francis, an overweight CubanAmerican student, Lopate seeks to befriend her, and portray her as a kindred soul, with a comparable sensibility to his own. Francis becomes Lopate's Fedka, in a refreshing twist on the portrait of the student who inspires the teacher by resembling the teacher: the awkward concerns with difference that haunts teaching memoirs momentarily vanishes in Lopate's and Francis's recognition of shared interests. Lopate has the sense to deflate his portrait of Francis and his friendship with her with humor, and we learn, at the end of his description of her, that he tried to lend her The Best Short Stories of Dostoevsky, "because he was the first writer who changed my life" (318).

Herndon, in a chapter length portrait of a student in How To Survive In Your Native Land, takes the student portrait and turns it, like Lopate, into a remarkably nuanced and funny exploration of the attempt to know one self and others. Titled The Price of Amphibians, the portrait and the chapter lead off with a quote from 
Wittgenstein - “An expression only has meaning within the stream of life"---and announces itself as a meditation on alienation and its remedies. It quickly cuts to a description of Herndon reading a student's cumulative folder and coming across the phrase "identifies with amphibians." Richard, the twelve year old described in the cumulative folder, soon arrives with a water dog, a kind of salamander, which he presents to Herndon and the class.

The rest of the chapter is a funny, warm, and troubled account of Richard, and of Herndon's failure to be the teacher he needs. The portrait reads likes a masterful short story, but its poignancy seems particularly apparent now when Richard would most likely be simply labeled as a child on the autistic spectrum, rather than as an individual, as Herndon would have it, who has been cut off from the stream of life and alienated, and who needs to be drawn back in through good teaching, but may in fact paradoxically know more about the stream of life and how to avoid alienation than those who are supposedly trying to save him from those problems. In other words, Herndon's portrait of Richard, his essentially literary take on Richard's problems, seems hard to imagine in the context of contemporary schools, with their myriad of analytical apparatuses for diagnosing and labeling quirky student behavior, but luckily we have the memoir itself, with descriptions of Richard's humungous, convoluted, hand-drawn maps and his surprising friendship with Tizzo, the toughest boy in the class, to testify to the plausibility and worth of Herndon's self-reliant portrayal of a self-reliant student.

Vivian Gussin Paley, whose long writing career has stretched from 1979 to 2005. is the writer who has most successfully taken the student portrait, as used by the 
sixties/seventies teacher-writers, and moved it forward as a form of character development, and commentary on relationship-based pedagogy. Awarded a McArthur grant and a National Book Award life time achievement award for her numerous memoirs of teaching, many of which are still in print, Paley shifts the focus of the student portrait from older school age children to younger kindergarten and preschool children. As early as her first book from 1979, White Teacher, Paley uses portraits of kindergarten and nursery school students to scrutinize her own failures, limitations, and possibilities as a teacher, as well as to document the development of individual children. This tendency to use the student portrait as simultaneously a description of someone else and as a form of self-scrutiny was very much present in the work of Tolstoy and the sixties/seventies memoirists, but Paley heightens it and moves it to the level of an art form, producing a remarkable body of work, which has, perhaps, not received due attention because of its focus on the lives of young children, a subject often viewed as both trivial and sentimental.

Like Tolstoy and the sixties/seventies memoirists, Paley places children's stories at the center of both her writing and her pedagogy, as she describes classes built around the attempt to solicit children's narratives. Paley, perhaps even more than Tolstoy or the sixties/seventies memoirists, seems to recognize how the student portrait allows her to know a particular student as a teacher, and to create a particular character as a writer. In The Boy Who Would Be a Helicopter (1990), a teaching memoir focused around the account of a boy who is a loner and an outsider, Paley describes her method of teaching and writing in a way that illuminates her approach to the student portrait: 
For me the questions are: How can each day's priorities and attachments be used to further an environment in which children tell us what they think? And what happens to those who remain on the outside?

Jason is such a child. He speaks only of helicopters and broken blades, and he appears indifferent to the play and stories that surround him. He has his own design for learning and, so far, it seems different from everyone else's.

This makes Jason a valuable class member and an important character in a book about teaching, for one does not teach in the abstract. A style of teaching is best illuminated by those who do not meet the teacher's expectations. These are the children who shed the strongest light upon the classroom and, this year, Jason carries the beacon, fastening it determinedly to the inside of his helicopter house. He presents a vivid image, but how do I mark his growth. (11)

Paley recognizes the outsider, students such as Jason in her class and Richard in Herndon's class, as a figure with inherent literary interest, as well as an educational challenge, a student in need of a relationship-based pedagogy, which fosters connection to others. Outsiders, as literary figures, have a long history in Romantic and Modern literature, but have not, by and large, been nursery school-age children, and part of the originality of Paley's work resides in this shift in scale, this movement of the outsider narrative from the large world of adults to the small world of very young children. Speaking of Jason, Paley states "He is, for me, the quintessential outsider, beyond race, place, or age" (xi). Beginning with the declaration that Jason's outsider status makes him both a "valuable class member and an important character in a book about teaching" (11). Paley's teaching and writing intentions flow into each other in a fluid form, linking a conception of children as students in a teacher's class and children as characters in a writer's book. 
Not surprisingly the next sentence after the description of Jason as both a student and a character, uses the language of literary criticism to describe teaching: "a style of teaching is best illuminated..." (11). At the end of the paragraph, a literary sensibility and a pedagogical sensibility are precisely balanced in a single sentence, like a perfect seesaw or scale, weighted between the two forms of interpretation: "He presents a vivid image, but how do I mark his growth." "Vivid image" comes from the lexicon of literature and literary criticism and "growth" comes from the lexicon of education. Paley balances the two lexicons as she contemplates the enigma which is Jason.

What, one might ask, is the advantage for education and literature of the careful balancing act Paley performs? For education, the introduction of a literary perspective-the tendency to view a student as a character-- seems to be at once a kind of violence and a kind of opening-up of possibilities: it freezes the student in the teacher-writer's narrative, and also makes the imagination of a counter narrative, which differs from the problematic class narrative, possible. For literature, the self-conscious introduction of students as characters and the classroom as a setting has the potential to expand the literary territory explored in previous memoirs of teaching, as well as in novels set in classrooms. The introduction of "real" students as characters also blurs the lines between fiction and nonfiction in a way that creates a puzzling frisson found in so much contemporary creative nonfiction.

A number of recent memoirs of teaching show the influence of Paley's approach, in theresp use of individual student portraits to develop literary characters and a relationship-based pedagogy. Jane Katch, a teacher who worked with Paley, has used the 
individual student portraits in two memoirs aimed primarily at teachers and parents of young children: Under Deadman's Skin: Discovering the Meaning of Children's Violent Play (2002) and They Don't Like Me: Lessons on Bullying and Teaching and Teasing (2004). Jonathan Mooney in The Short Bus: A Journey Beyond Normal (2007) uses the portrait of individual students, in much the same way as both Herndon and Paley, to advocate for a more just, more enabling view of students whose differences, particularly their autistic tendencies, often results in their labeling and exclusion.

Julie Diamond, a New York kindergarten teacher with twenty five years of experience in the classroom, recently used student portraits to develop characters in her memoir of teaching, Welcome to the Aquarium (New Press, 2008), another book which marks the migration of the genre from popular presses to university and independent presses, as well as the "aging" and feminizing of the genre, as it moves from being primarily a young man's genre, written in response to a single year of teaching, to being a genre written by older men and women, in response to a lifetime of teaching.

Just as Paley used her extended portrait of Jason, an outsider, to structure The Boy Who Would Be a Helicopter, Diamond uses her extended portrait of Henry, an outsider, to structure Welcome to the Aquarium. From what I was calling snapshot and echo in the portraits of the sixties and seventies teacher-writers--in which we get a single, highly focused portrait of a student followed by intermittent appearances of the student throughout the narrative---we have moved to a seemingly conscious decision to make the teacher's relation to particular students' the focus of the narrative. Sam Swope in I am a Pencil also uses this extension of the student portrait from a snapshot and echo format to 
a method for substantial character development, in his multiple portraits of Miguel, Maya, Fatma, Su Jung, Mei Kei and Rosie.

Like Lopate, Swope creates a core group of highly detailed, student portraits and a small group of less detailed student portraits, a theme and a melody, a bunch of kids who are very noticeable and a bunch of kids who are not. In Lopate's and then in Swope's work, class social dynamics turn into literary form. Unusual students— - gifted, troubled, odd, quirky kids-- often come to dominate or at least preoccupy the social narratives that emerges in a classrooms, while other less intense students have seemingly less of an impact on the classroom social narratives. Similarly, in Lopate's and Swope's work, through the use of individual student portraits, the unusual students carry the narrative forward, while the less intense students take on the roles of minor characters.

In describing, Lopate's and Swope's cast of secondary characters I purposely use the word "less intense" rather than "more conventional" because in their careful observation and interest in individual students, authors of memoirs about teaching seem to very intentionally dissolve the notion of the "conventional" "average" student, suggesting instead that any student, any character, and by extension any person, looked at under the lens of portraiture, the frame of literary narrative, is too particular and idiosyncratic to be considered conventional. It is almost as though a certain power of magnification, brought on by the passionate scrutiny of portraiture, precludes the generalizations and lack of focus necessary to see students and characters as conventional, average, or typical. This dissolving of the conventional and heightening of the particular for moral purposes, to make the point that all students are potential 
characters, may be one of the significant ethical insights of student portraiture as a form of writing commonly employed in memoirs.

In an interesting twist on the use of student portraits in memoir, Sarah LawrenceLightfooot, a sociologist known for her work in education, wrote a book called The Art and Science of Portraiture (2002) that essentially lifted the student portrait out of the context of memoir and placed it in the context of qualitative educational research, where it was initially greeted as highly innovative and perceptive, but was eventually criticized for its occlusion of subjectivity, its unselfconscious essentializing of one person's interpretation of a particular student. I am less concerned with whether Lightfoot's concept of portraiture is a valid form of qualitative educational research, than with the fact that the very act of questioning its validity in a research context points to portraiture's essentially fictionalizing tendencies, which are valued in the realm of literature, but are not necessarily easily transferable to other modes of inquiry. From Tolstoy in the1860s to Julie Diamond in 2008, portraits of students provide a means of addressing a narrative problem that pervades memoirs of teaching: how to develop characters with believable interior lives. In the processes of using individual student portraits to solve the problem of characterization in memoir of teaching, memoirsits may also have found an innovative way to represent interiority in creative nonfiction. Lee Gutkind in a recent book on the craft of creative nonfiction, Keep it Real, points out that "inner thoughts and feelings of characters appear regularly in fiction," but wonders whether "the interior life is fair game for the nonfiction writer as well" (68). Gutkind claims that brief, occasional reflections on nonfiction characters' inner lives, in 
the form of "interior reports" are alright, but in the best memoirs of teaching, the surmised interior life of the characters, represented in individual student portraits, become as much a part of the plot and the point of the narrative as any other more outward, objectively reported descriptions of characters' behavior. In other words, student portraits stake a claim for the representation of interiority in creative nonfiction, turning the surmised representation of others' interiority into a significant aspect of creative nonfiction. One could essentially think of student portraits in memoirs of teaching as fulfilling the same function as free indirect discourse or interior monologue in fiction. The way that student portraits represent character's interior lives, however, rests not in a form of omniscient narration, but in a form of narration that foregrounds relationship, the connection between the "I" of the teacher-writer and the "thou" of the student.

We have looked at how teacher-writers have used three types of experiences in schools---making things together, field trips, and student portraits - to simultaneously advocate a relationship-based pedagogy and create compelling characters. What making things, field trips, and student portraits all have in common, in addition to their usefulness in the development of a relationship-based pedagogy and a character-driven narrative, is their common connection to self-reliant forms of teaching. In its dependence on individual resources and creativity, making things inherently fosters self-reliance in teachers and students. In its departure from the daily routine, the field trip in its own small, geographical way maps out a self -reliant route, different from the well-worn path between the front door of the school and the classroom. In its focus on the singular 
characteristics of individual students and its capacity to honor quirkiness and individuality, student portraits pay tribute to the value of self-reliance. In short, the memoirists' most obvious means of developing characters - portraying people making things together, field trips, and student portraits - all honor self reliance, in one form or another.

What fosters relationship among people in classrooms---making things, going places, and composing portraits---turns out to also be a means of portraying relationship among characters, suggesting that what constitutes good teaching may also constitute good narrative writing. Given that the sixties and seventies memoirists were working without many prior models, they needed to put together their memoirs self-reliantly much as they put together their classes self-reliantly from what they themselves deemed valuable. In their prose one can sense their excitement at having found innovative ways to turn lessons into stories, pedagogy into narrative. The teacher cultivating relationships between students and the writer cultivating relationships between characters join and overlap in the pages of teacher writers' memoirs, suggesting a connection between the processes of teaching and the processes of writing, two self-reliant, Emersonian tasks, that both always embody some aspect of improvisation and becoming. 


\section{Epilogue: Stories of Self-Reliance}

The objection to conforming to usages? that have become dead to you is, that it scatters your force. It loses your time and blurs the impression of your character.

\section{Emerson, Self-Reliance}

It is said that the average teacher is incompetent to take any part in laying out the course of study or in initiating methods of instruction or discipline. Is not this type of argument which has been used from time immemorial, and in every department of life, against the advance of democracy? What does democracy mean save that the individual is to share in determining the conditions and aims of his own work; and that, upon the whole, through the free and mutual harmonizing of different individuals, the work of the world is better done than when planned, arranged, and directed by a few, no matter how wise or of how good intent that few? How can we justify our belief in the democratic principle elsewhere, and then go back entirely upon it when we come to education?

Dewey, Democracy in Education

On a February noon with the Bay Area fog beginning to lift, Maria eats lunch with two first grade teachers in a classroom within the main building, discussing the afternoon's science activity. The other two teachers, while not enamored with the pre-packaged activity, have decided to use the materials pretty much as directed. The DTE graduate describes the activity she will use instead - a "sink or float" activity that teaches the same concepts as the pre-packaged lesson and uses the same materials but provides active engagement for students. Unlike the pre-packaged lesson, Maria's re-design engages students in both the recording of data and in the generation and testing of hypotheses based on the data. The other teachers laugh_and ask if she "woke with this one." "No," she responds "It was in the shower this time." On the way back to the classroom, she explains that the packaged curriculum, like many others, dumbs down the content and "leaves out kids entirely." In order to introduce higher order skills and strategies that can engage her students, Maria explains how she has replaced the language arts program; tweaked the math program, and created a new science program. (211-212)

Linda Darling-Hammond, The Flat World and Education, Teachers College Press, 2010

The quotes from Emerson and Dewey describe self-reliance as an idea, as a concept applicable to life and teaching. The quote from Linda Darling-Hammond's 
recent book on school reform, taken from a section on teacher preparation programs, is an anecdote about self-reliance, a mini-story about how teacher education programs that cultivate intelligent and responsible self-reliance in their graduates produce better teachers.

Between Emerson's and Dewey's ideas about self-reliance and Linda DarlingHammond's anecdote about self-reliance, are the memoirs of teaching from the sixties and seventies. The sixties and seventies memoirists turned ideas about self-reliance, particularly Emerson's and Dewey's, into narratives about self-reliance. In moving selfreliance from practice to plot, in creating a compelling story of self-reliant teaching, the sixties and seventies memoirists enabled Emerson's and Dewey's beliefs about the connection between self-reliance and democratic education to take root in our culture, for better and for worse. The stories of self-reliant teaching told by the sixties and seventies memoirists may have paved the way for a lot of awful movies and some irresponsible teaching, but they have also enabled us to see that a teacher's ability to inspire students and deal with the complexity inherent in teaching and learning often hinges on their capacity for self-reliance.

I watched a group of second graders in an urban elementary school perform, with great enthusiasm and pleasure, a play they wrote about the first ten books of the Odyssey. Odysseus's small crew tied themselves to the legs of a desk as they sailed past the sirens. Polyphemus held aloft her single cardboard eye as she called out to Nobody. The play was aligned to state standards in so far as the standards encourage exposing students to the literature of the past, but nowhere in the school's, district's, or state's curriculum 
were there any directions about teaching the Odyssey, and nowhere in the students' reading textbook was their a retelling of the Odyssey. The teacher had designed the unit herself and had gotten the materials from the library. This is the type of self-reliant teaching the sixties and seventies memoirists celebrated in their narratives. When this type of self-reliant teaching eschews petulant individualism, when it is connected to genuine collaboration, it still has the capacity to invigorate schools. 


\section{Notes}

1. The only two book length studies I know of on sixties and seventies educational writers are Jane Isenberg's Going By The Book (Bergen and Garvey, 1994) and Kirsten Olsen's Schools as Colonizer (Verlag, 2008). Jane Eisenberg describes how her own teaching was influenced by the work of Sylvia Ashton-Warner, Bel Kaufman, E.R. Braithwaite, John Holt, and Herbert Kohl. Kirsten Olsen presents John Holt, Ivan Illich, Paul Goodman, Jonathan Kozol, Herbert Kohl and George Dennison as educational critics, who recognized the ways in which schools, as institutions, often stifle, rather than promote genuine learning.

2. Len Gougeon in Virtue's Hero: Emerson, Antislavery and Reform attributes the tendency to view Emerson, in general, and the concept of self-reliance, in particular, as antithetical to social reform to late nineteenth and early twentieth century reinterpretations of his work, particularly those of the Reverend William Lawrence and the Harvard University President, Charles W. Eliot.

3. Cathryn McConaghy in "Teaching Intimacies" points out that after seventeen years of living and teaching in Maori communities Sylvia Ashton-Warner became fluent in speaking the Maori language.

\section{Works Cited}

Appiah, Kwame Anthony. Cosmopolitanism: Ethics In A World Of Strangers. New York: Norton, 2006.

Archambault, Reginald. Introduction. Tolstoy on Education. By Leo Tolstoy. Trans. Leo Weiner. Chicago: University of Chicago Press, 1967.

Ayers, Willimiam. Forward. The Herb Kohl Reader. By Herbert Kohl.

New York: New Press, 2009.

Baldwin, James. "A Talk to Teachers." James Baldwin Collected Essays. 
Ed. Toni Morrison. New York: The Library of America, 1998

Begaudeau, Francois. The Class. Trans. Linda Asher. New York: Seven Stories, 2009.

Bhabha, Homi K. The Location of Culture. 1994. London: Routledge, 2007. Print.

Bickman, Martin. Minding American Education. New York: Teacher's College Press, 2003.

Birkerts, Sven. The Art of Time in Memoir. Saint Paul, MI: Greywolf Press, 2008.

Brown, Dan. The Great Expectations School. New York: Arcade, 2007.

Buell, Lawrence. Emerson. Cambridge, MA: Harvard University Press, 2003.

Cafaro, Philip. Thoreau's Living Ethics: Walden and the Pursuit of Virtue. Athens, GA: University of Georgia Press, 2006.

Codell, Esme Raji. Educating Esme. 1999. Chapell Hill, NC: Algonquin Books, 2009. Print.

Darling-Hammond, Linda. The Flat World And Education. New York: Teachers College Press, 2010.

Dargis, Manohla. “In 'Half-Nelson,' A Student Knows A Teacher's Secret.” New York Times 11 August, 2008. NYTimes.com. Web. 30, Aug. 2009.

Decker, Sunny. An Empty Spoon. 1969. New York: Harper and Row, 1970. Print. 
Dewey, John. "Democracy in Education.” Classroom Conversations. Ed. Alexandra Milleta and Maureen Miletta. New York: New Press, 2008.

Dennison, George. The Lives Of Children. 1969. New York: Random House; Portsmouth, NH: Boynton, Cook, 1999. Print.

Dimmock, Wai Chee. Through Other Continents: American Literature Across Deep Time Princeton, NJ: Princeton UP, 2007.

Duncan, Arne. "Q and A with Education Secretary Arne Duncan” NEA Today, May 2009. Web. 30 Aug. 2009.

Diamond, Julie. Welcome to the Aquarium. New York: New Press, 2008.

Diehl, Huston. Dream Not of Other Worlds. Iowa City: University of Iowa Press, 2007.

Eaton, Susan. The children In Room E4. 2007. Chapel Hill, NC:

Algonquin Books, 2009. Print.

Edmundson, Mark. Teacher. 2002. New York: Random House, 2003. Print.

Emerson, Ralph Waldo. Emerson's Prose and Poetry. Ed. Joel Porte and Saundra Morris. New York: Norton, 2009.

Engel, Susan. "What It Takes To Become a Great Teacher." Teachers College Record. Web. 17 January 2010.

Fader, Daniel. The Naked Children. 1971. Portsmouth, NH: Boynton/ Cook, 1996. Print. 
Farber, M.A. “Teachers Critical of Schools are Turning Into Authors.” New York Times 25 March. 1968: 54.

Gougeon, Len. Virtue's Hero: Emerson, Anti-Slavery, and Reform. Athens: U of Georgia P, 1990.

Greene, Mary Frances, and Orletta Ryan. The Schoolchildren. New York: Pantheon, 1964.

Goodnough, Abby. Ms. Moffett's First Year. 2004. New York: PublicAffairs, 2006.

Greene, Maxine. The Dialectic of Freedom. New York: Teacher's College Press, 1988.

Gruwell, Erin. The Freedom Writer's Diary. New York: Broadway Books, 1999.

Gutkind, Lee, ed. Keep It Real. New York: Norton, 2008.

Halpin, Brendan. Losing My Faculties. New York: Random House, 2004.

"Harvard Civil Rights Project Reports Rise in School Segregation.” Civil Rights Monitor. Civilrights. Org., Fall, 1999. Web. 20 August 2009.

Haskins, Jim. Diary of a Harlem Schoolteacher. 1979. New York: Grove Press; New York: New Press, 2008. Print.

Herndon, James. The Way It Spozed To Be. New York: Bantam, 1965. 
Herndon, James. How To Survive In Your Native Land. 1971. Portsmouth, NH: Boynton/ Cook, 1997. Print.

Isenberg, Jane. Going By The Book. Wesport, CT: Greenwood, 1994.

Katch, Jane. Under Deadman's Skin: Discovering the Meaning of Children's Violent Play. Boston: Beacon Press, 2002.

Katch, Jane. They Don't Like Me: Lessons On Bullying and Teasing From A Preschool Classroom. Boston: Beacon, 2004.

Kateb, George, Emerson and Self-Reliance. Lanham, MD: Rowan and Littlefield, 2002.

Klaus, Ian. Elvis is Titanic: Classroom Tales From The Other Iraq New York: Knopf, 2007.

Kohl, Herbert. 36 Children. 1967. New York: NAL Books; New York: Plume, 1988. Print.

Kohl, Herbert. Interview. “Reading in(to) Sylvia: Interviews on Asthon-Warner's Influence.” By Kathleen Connor and Linda Radford. Provocations: Sylvia Ashton-Warner and Excitability in Education. Ed. By Judith P. Robertson And Cathryn McConaghy. New York: Peter Lang, 2006.

Kohl, Herbert. “An Open Letter to Arne Duncan.” Rethinking Schools, Vol.23. no.4, Summer, 2009. Web. 30 August 2009. 
Kozol, Jonathan. Death At An Early Age. 1967. Boston: Houghton Mifflin; New York: Plume, 1985. Print.

Kozol, Jonathan. On Being A Teacher. 1981. Glasgow: Oneworld, 2009. Print.

Kozol, Joathan. Letters To A Young Teacher. 2007. New York: Random House.

Larsen, Thomas. The Memoir and the Memoirist. Athens, $\mathrm{OH}$ :

Ohio University Press, 2007.

Lawrence-Lightfoot, Sara and Jessica Hoffman Davis. The Art and Science of Portraiture. San Francisco: Jossey-Bass, 1997.

Lehmann-Haupt. "Store Front Schools and the Good Life." New York Times 10 October 1969. Web. 30 Aug., 2009.

Lopate, Philip. Being With Children. 1975. New York: Doubleday; New York: New Press, 2008. Print.

Marshall, Sybil. An Experiment in Education. Cambridge: Cambridge University Press, 1966.

McCartney, Kathleen. Letter. New York Times 2 Nov. 2009. Web. 24 Jan. 2010.

McConaghy, Cathryn. "Teaching Intamicies.” Provocations: Sylvia Ashton-Warner And Excitability in Education. Ed. Judith P. Robertson and Cathryn 
McConaghy. New York: Peter Lang, 2006.

Macdonald, Elizabeth and Dennis Shirley. The Mindful Teacher. New York: Teachers College Press, 2009.

Michie, Gregory. Holler If You Hear Me. 1999. New York: Teachers College Press, 2009. Print.

Mooney, Jonathan. The Short Bus: A Journey Beyond Normal. New York: Holt, 2007.

Morenson, Greg., and David Oliver Relin. Three Cups of Tea. New York: Viking Penguin, 2006.

Nafisi, Azar. Reading Lolita in Tehran. New York: Random House, 2003.

Olsten, Kirsten. Schools As Colonizers. Saarbrucken, Germany: VDM, Verlag, 2008.

Packer, George. The Village of Waiting. 1984. New York: Farrar, Straus, and Grioux, 2001. Print.

Paley, Vivian Gussin. The Boy Who Would Be a Helicopter. Cambridge, MA: Harvard University Press, 1990.

Paley, Vivian Gussin. White Teacher. Cambridge, MA: Harvard University Press, 1979.

Patri, Angelo. A Schoolmaster of the Great City. 1917. New York: New Press, 2007 
Print.

Pratt, Caroline. I Learn From Children. 1948. New York: Simon and Schuster, 1990. Print.

Proefriedt, William A. High Expectation: The Cultural Roots of Standards Reform In American Education. New York: Teachers College Press, 2008.

Richardson, Elwyn S. In the Early World. New York: Pantheon, 1964.

Robb, Daniel. Crossing The Water. New York: Touchstone, 2001.

Salzman, Mark. Iron and Silk. New York: Vintage, 1987.

Salzman, Mark. True Notebooks. New York: Vintage, 2007.

Samway, Patrick, S. J. Educating Darfur Refugees. Scranton, CT: University of Scranton Press, 2007.

Schults, Brian D. Spectacular Things Happen Along the Way. New York: Teachers College, 2008.

Scrimgeour, J.D. Themes Fro English B. Athens, GA: University of Georgia Press, 2006.

Sentilles, Sarah. Taught By America. Boston: Beacon Press, 2005.

Spivak, Gayatri Chakravorty. Other Asias. Malden, Mass: 2008.

Sun, Nilaja. No Child...New York: Dramatists Play Service, 2008. 
Swope, Sam. I Am a Pencil. New York: Henry Holt, 2005.

Tolstoy, Leo. Tolstoy as Teacher: Leo Tolstoy's Writings On Education. Ed. Bob Blaisdell. Trans. Christopher Edgar. New York: Teacher's and Writer's Collaborative.

Teicher Khadaroo, Stacey. "Lessons From The Most Successful Schools Abroad. Christian Science Monitor 24 Mar. 2009. Web. 30 Aug. 2009.

Warner, Sylvia-Ashton. Teacher. 1963. New York: Simon and Schuster, 1986. Print. 